\title{
Assessment of the Use of Nitrogen Trifluoride for Purifying Coolant and Heat Transfer Salts in the Fluoride Salt-Cooled High-Temperature Reactor
}

RD Scheele

AM Casella

September 2010

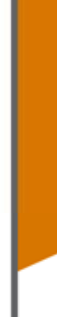




\title{
DISCLAIMER
}

This report was prepared as an account of work sponsored by an agency of the United States Government. Neither the United States Government nor any agency thereof, nor Battelle Memorial Institute, nor any of their employees, makes any warranty, express or implied, or assumes any legal liability or responsibility for the accuracy, completeness, or usefulness of any information, apparatus, product, or process disclosed, or represents that its use would not infringe privately owned rights. Reference herein to any specific commercial product, process, or service by trade name, trademark, manufacturer, or otherwise does not necessarily constitute or imply its endorsement, recommendation, or favoring by the United States Government or any agency thereof, or Battelle Memorial Institute. The views and opinions of authors expressed herein do not necessarily state or reflect those of the United States Government or any agency thereof.

\author{
PACIFIC NORTHWEST NATIONAL LABORATORY \\ operated by \\ BATTELLE \\ for the \\ UNITED STATES DEPARTMENT OF ENERGY \\ under Contract DE-AC05-76RL01830
}

Printed in the United States of America

$$
\begin{aligned}
& \text { Available to DOE and DOE contractors from the } \\
& \text { Office of Scientific and Technical Information, } \\
& \text { P.O. Box } 62 \text {, Oak Ridge, TN } 37831-0062 \text {; } \\
& \text { ph: }(865) 576-8401 \\
& \text { fax: (865) 576-5728 } \\
& \text { email: reports@adonis.osti.gov }
\end{aligned}
$$

Available to the public from the National Technical Information Service 5301 Shawnee Rd., Alexandria, VA 22312 ph: (800) 553-NTIS (6847)

email: orders $a$ ntis.gov $<$ http://www.ntis.gov/about/form.aspx $>$ Online ordering: http://www.ntis.gov 


\section{Assessment of the Use of Nitrogen Trifluoride for Purifying Coolant and Heat Transfer Salts in the Fluoride Salt-Cooled High-Temperature Reactor}

RD Scheele

AM Casella

September 2010

Prepared for

the U.S. Department of Energy

under Contract DE-AC05-76RL01830

Pacific Northwest National Laboratory

Richland, Washington 99352 



\section{Summary}

The Pacific Northwest National Laboratory, in support of the Oak Ridge National Laboratory's program to investigate an advanced molten salt cooled reactor concept for the U.S. Department of Energy, evaluated potential nitrogen trifluoride $\left(\mathrm{NF}_{3}\right)$ use as an agent for removing oxide and hydroxide contaminants from candidate coolants. These contaminants must be eliminated because they increase the corrosivity of the molten salt to the detriment of the materials of containment that are currently being considered. The baseline purification agent for fluoride coolant salts is hydrogen fluoride (HF) combined with hydrogen $\left(\mathrm{H}_{2}\right)$.

Using $\mathrm{HF} / \mathrm{H}_{2}$ as the reference treatment, we compare $\mathrm{HF}$ and $\mathrm{NF}_{3}$ industrial use, chemical and physical properties, industrial production levels, chemical, toxicity, and reactivity hazards, environmental impacts, effluent management strategies, and reaction thermodynamic values.

Because $\mathrm{NF}_{3}$ is only mildly toxic, non-corrosive, and non-reactive at room temperature, it will be easy to manage the chemical and reactivity hazards during transportation, storage, and normal operations. Industrial experience with $\mathrm{NF}_{3}$ is also extensive because $\mathrm{NF}_{3}$ is commonly used as an etchant and chamber cleaner in the electronics industry. In contrast HF is a highly toxic and corrosive gas at room temperature but because of its significance as the most important fluorine-containing chemical there is significant industrial experience managing HF hazards.

$\mathrm{NF}_{3}$ has been identified as having the potential to be a significant contributor to global warming and thus its release must be evaluated and/or managed depending on the amounts that would be released. Because of its importance to the electronics industry, commercial technologies using incineration or plasmas have been developed and are used to destroy the $\mathrm{NF}_{3}$ in a facility's gaseous effluent stream. A process has been developed and used to recover and recycle $\mathrm{NF}_{3}$. In addition, the electronics industry is actively pursuing alternative methods to control $\mathrm{NF}_{3}$ releases. In comparison, $\mathrm{HF}$ has not been identified to be a potential global warming gas nor has it been determined to have any other environmental affect. Also because of the high solubility of HF in water and aqueous caustic solutions, the HF industry has developed and used aqueous scrubbers to effectively prevent its release into the environment.

Care appears to be necessary when using $\mathrm{NF}_{3}$ in a plant. Precautions must be taken to prevent adiabatic compression and make sure that $\mathrm{NF}_{3}$ thermal decomposition does not occur in unplanned locations. The system must be engineered to avoid the use of ball valves and sharp bends.

The materials of construction that will be required to contain $\mathrm{NF}_{3}$ and anhydrous $\mathrm{HF}$ will be similar. If water is present such as in the process effluent, $\mathrm{HF}$ is more corrosive than $\mathrm{NF}_{3}$ and its containment would require nickel or nickel-based alloys. Both of these fluorinating agents become more reactive with increasing temperature and would require pure nickel or nickel-based alloys for containment until the gas stream has cooled.

With respect to the cost of the fluoride, $\mathrm{HF}$ is about one third the cost of $\mathrm{NF}_{3}$ on a fluorine basis. Of the fluorine-containing chemicals, more $\mathrm{HF}$ is produced than any other. $\mathrm{NF}_{3}$ is produced on an industrial scale and its capacity has grown each year since being identified as a useful etchant. 
Both $\mathrm{NF}_{3}$ and $\mathrm{HF}$ have been demonstrated to be effective at removing oxide, hydroxide, and water contamination from fluoride salts during melt processing of fluoride glasses while HF in combination with $\mathrm{H}_{2}$ has been demonstrated to be effective for some of the candidate coolant salts and some of their individual constituents such as beryllium oxide (BeO). HF has a limited solubility in molten $66 \mathrm{~mol} \%$ $\mathrm{LiF}-33 \mathrm{~mol} \% \mathrm{BeF}_{2}$ indicating that treatment with $\mathrm{HF}$ will result in free $\mathrm{F}^{-}$in $\mathrm{HF}$-treated fluoride salts. $\mathrm{H}_{2}$ 's flammability and potential explosivity introduces additional hazards to its use.

With respect to chemical viability, as measured by reaction free energies, $\mathrm{NF}_{3}$ is the stronger fluorinating agent when compared to HF. For all postulated contaminants the calculated free energies for treatment by $\mathrm{NF}_{3}$ were negative, indicating that the reactions were favorable and should occur provided there are no kinetic barriers. In contrast, HF's fluorinating power declined with increasing temperature, and in a couple of instances the reaction free energy became slightly positive (e.g., $\mathrm{BeO}$ above $700^{\circ} \mathrm{C}$ ), indicating that use of excess HF would be required for the fluorination to occur or that the product water would have to be removed to force the reaction to occur. Experimental studies are required to demonstrate that the predicted chemical viability is real and to determine the conditions that are necessary to remove the oxide and hydroxide contaminants.

Although the plan is to remove any broken fuel debris from the primary coolant by filtering, we evaluated the potential use of $\mathrm{NF}_{3}$ as an agent to remove the uranium, silicon carbide, and carbon using thermodynamics. This evaluation indicates that each of these fuel constituents should be converted to volatile fluorides by $\mathrm{NF}_{3}$.

Based on our evaluation, $\mathrm{NF}_{3}$ appears to be a viable and effective purification agent for removing oxide and hydroxide contaminants in the coolant salts of the fluoride salt-cooled high temperature reactor test system. Experimental studies are required to determine the conditions required for the postulated purification process reactions to occur. In general, most of the complications with $\mathrm{NF}_{3}$ use can be overcome by proper engineering. However, an evaluation of the need and viability of existing technologies to control $\mathrm{NF}_{3}$ release would be required. 


\section{Acknowledgments}

The authors commend Brian Rapko for his technical review of this report and Rick Wittman and Bruce McNamara for their attention to detail in reviewing the calculations. Thanks also to Susan Ennor and Mike Parker for their editing and production support. 



\section{Acronyms and Abbreviations}

ACGIH

CFR

CVD

DOE

DRACS

FHR

FHR-TS

GWP

HMIS

IR

ISO

MSR

MSRE

NFPA

NIOSH

PTFE

PCTFE

ORNL

OSHA

PEL

PNNL

RAP

REL

TLV

TRISO
American Conference of Governmental Industrial Hygienists

Code of Federal Regulations

chemical vapor deposition

U.S. Department of Energy

Direct Reactor Auxiliary Cooling System

fluoride salt-cooled high temperature reactor

fluoride salt-cooled high temperature reactor test system

global warming potential

Hazardous Material Identification System

infrared

International Organization for Standardization

molten salt reactor

molten salt reactor experiment

National Fire Protection Association

National Institute for Occupational Safety and Health

polytertafluoroethylene

polychlorotrifluoroethylene

Oak Ridge National Laboratory

Occupational Safety and Health Administration

permissible exposure limit

Pacific Northwest National Laboratory

Reactive Atmosphere Processing

recommended exposure limit

threshold limit value

tristructural-isotropic 



\section{Contents}

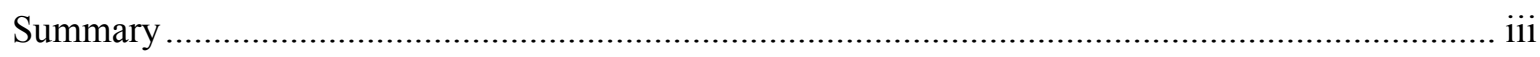

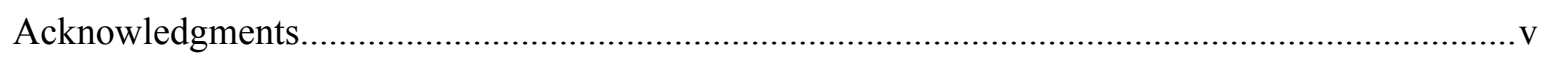

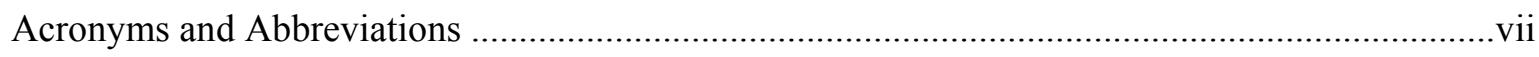

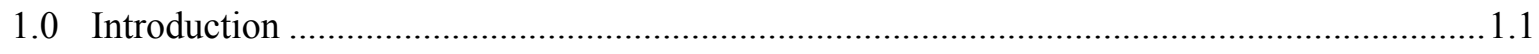

2.0 Candidate Coolant and Heat-Transfer Salts for FHR-TS ....................................................2.1

2.1 Contaminants in Coolant and Heat-Transfer Salts ......................................................... 2.1

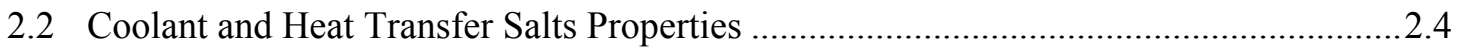

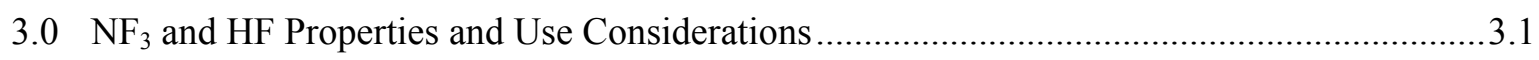

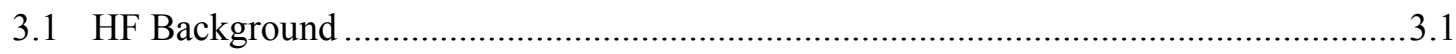

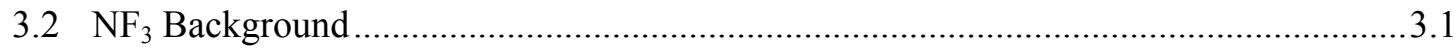

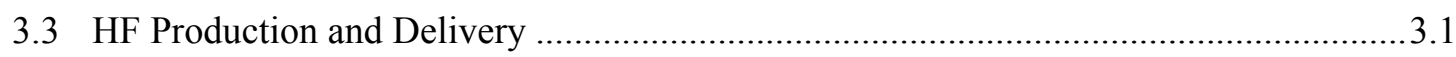

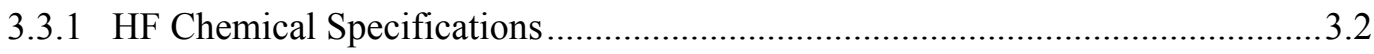

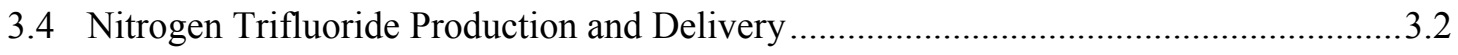

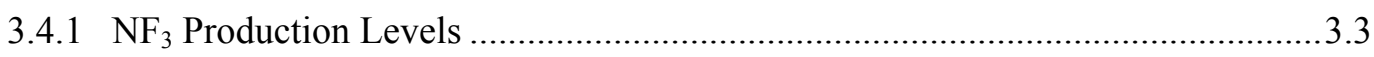

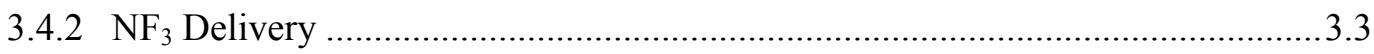

3.5 Nitrogen Trifluoride Chemical and Physical Properties ..............................................3.3

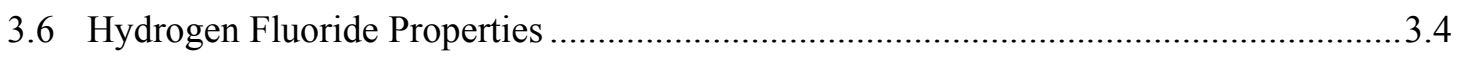

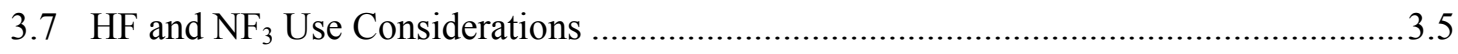

3.7.1 HF Health and Safety Considerations …........................................................... 3.6

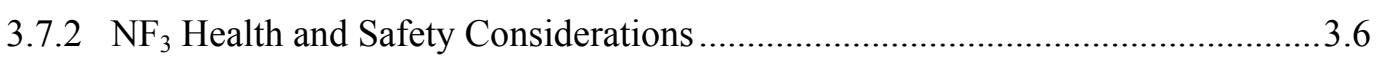

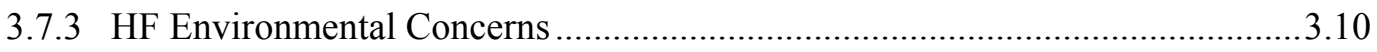

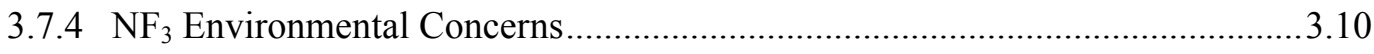

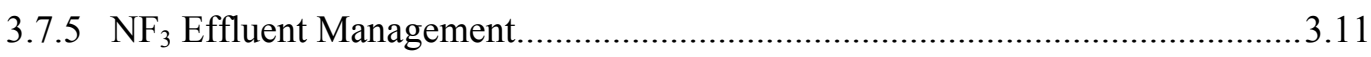

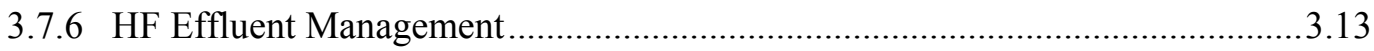

4.0 Reported $\mathrm{NF}_{3}$ and $\mathrm{HF}$ Use as Purification Agents for Fluorides ....................................... 4.1

4.1 Traditional Fluoride Coolant Purification ................................................................ 4.1

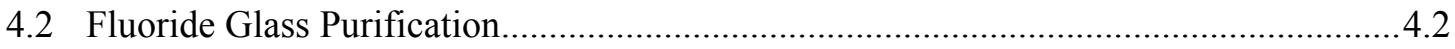

4.2.1 $\mathrm{NF}_{3}$ Purification of Fluoride Glasses.............................................................. 4.3

4.2.2 HF Purification of Fluoride Glasses .................................................................. 4.3

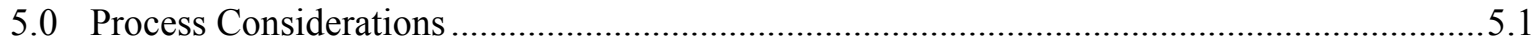

6.0 Thermodynamics of $\mathrm{NF}_{3}$ and HF Purification of MSR Coolant and Secondary Heat-Transfer

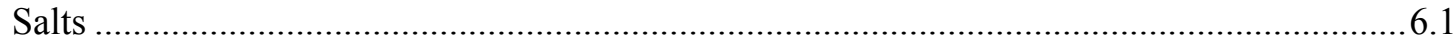

6.1 Flibe

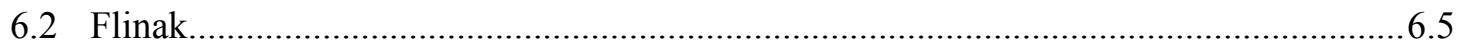

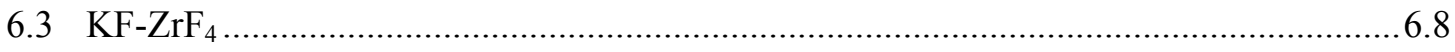

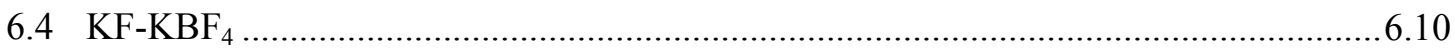

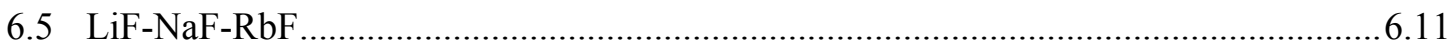




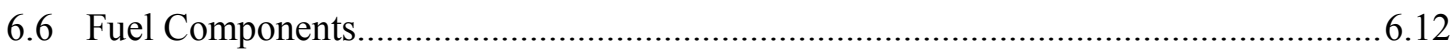

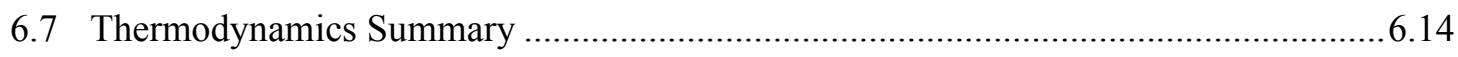

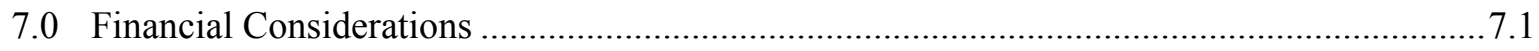

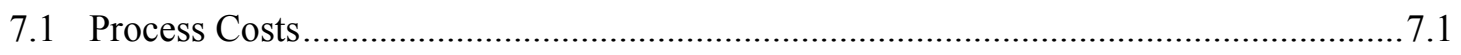

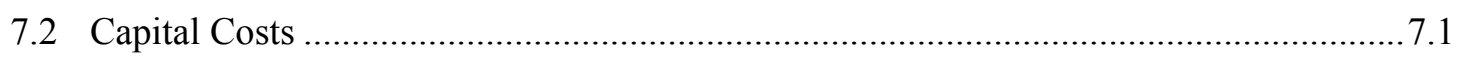

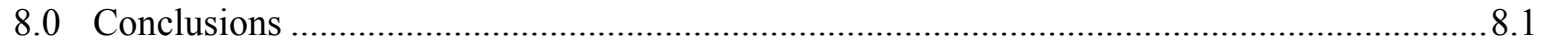

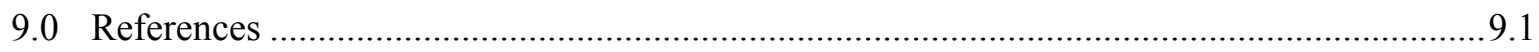




\section{Figures}

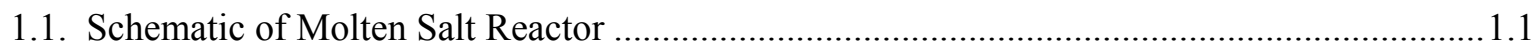

1.2. Conceptual Drawing of a Pebble Bed FHR and Power Generation Cycle ............................. 1.2

1.3. Overall FHR-TS Primary Heat Transfer Flow.................................................................. 1.3

2.1. Predicted Equilibrium Composition for Flibe Exposed to $\mathrm{H}_{2} \mathrm{O} / \mathrm{O}_{2} \quad$ …................................2.2

2.2. Predicted Equilibrium Composition for Flibe Exposed to $\mathrm{H}_{2} \mathrm{O}$..........................................2.2.2

2.3. Predicted Equilibrium Composition for Flinak Exposed to $\mathrm{H}_{2} \mathrm{O} / \mathrm{O}_{2}$...................................2.3

2.4. Predicted Equilibrium Composition for Flinak Exposed to $\mathrm{H}_{2} \mathrm{O}$......................................2.3

\section{Tables}

2.1. Melting Points of Candidate Primary, Intermediate, and DRACS Coolant Salts ..................2.4

3.1. Hydrogen Fluoride Product Specifications ....................................................................... 3.2

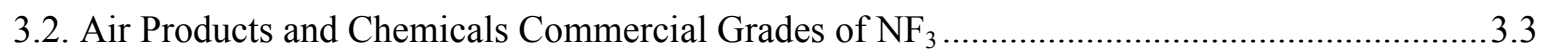

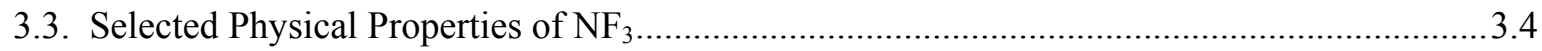

3.4. Selected Properties of Hydrogen Fluoride ...................................................................... 3.5

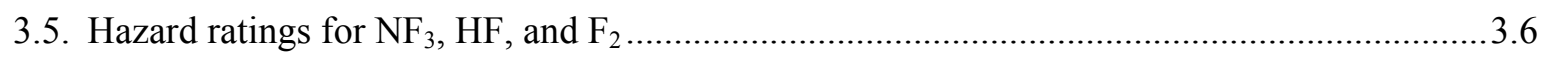

3.6. Time-Weighted Average $\mathrm{NF}_{3}$ and $\mathrm{HF}$ Occupational Exposure Limits/Levels .......................3.7

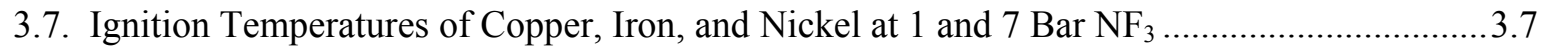

4.1. Impurities in Flibe Ingredients and Final Salt Used in JUPITER-II Testing ..........................4.2

6.1. Calculated Thermodynamic Values for Fluorination of $\mathrm{BeO}$ by $\mathrm{NF}_{3}$ and $\mathrm{HF}$.......................6.2

6.2. Calculated Thermodynamic Values for Fluorination of $\mathrm{BeO}$ by $\mathrm{NF}_{3}$ Producing $\mathrm{NO}_{\mathrm{x}} \ldots \ldots \ldots . . .6 .2$

6.3. Calculated Thermodynamic Values for Fluorination of $\mathrm{Li}_{2} \mathrm{O}$ by $\mathrm{NF}_{3}$ and $\mathrm{HF}$.....................6.3

6.4. Calculated Thermodynamic Values for Fluorination of $\mathrm{Li}_{2} \mathrm{O}$ by $\mathrm{NF}_{3}$ Producing $\mathrm{NO}_{\mathrm{x}} \ldots \ldots \ldots \ldots . . .6 .3$

6.5. Calculated Thermodynamic Values for Fluorination of $\mathrm{Be}(\mathrm{OH})_{2}$ by $\mathrm{NF}_{3}$ and $\mathrm{HF}$................6.4

6.6. Calculated Thermodynamic Values for Fluorination of $\mathrm{Be}(\mathrm{OH})_{2}$ by $\mathrm{NF}_{3}$ Producing $\mathrm{NO}_{\mathrm{x}} \ldots . .6 .4$

6.7. Calculated Thermodynamic Values for Fluorination of $\mathrm{LiOH}$ by $\mathrm{NF}_{3}$ and $\mathrm{HF}$......................6.4

6.8. Calculated Thermodynamic Values for Fluorination of $\mathrm{LiOH}$ by $\mathrm{NF}_{3}$ Producing $\mathrm{NO}_{\mathrm{x}} \ldots \ldots \ldots . .6 .5$

6.9. Calculated Thermodynamic Values for Fluorination of $\mathrm{Na}_{2} \mathrm{O}$ by $\mathrm{NF}_{3}$ and $\mathrm{HF}$....................6.5

6.10. Calculated Thermodynamic Values for Fluorination of $\mathrm{Na}_{2} \mathrm{O}$ by $\mathrm{NF}_{3}$ Producing $\mathrm{NO}_{\mathrm{x}} \ldots \ldots . . .6 .6$

6.11. Calculated Thermodynamic Values for Fluorination of $\mathrm{NaOH}$ by $\mathrm{NF}_{3}$ and $\mathrm{HF}$..................6.6

6.12. Calculated Thermodynamic Values for Fluorination of $\mathrm{NaOH}$ by $\mathrm{NF}_{3}$ Producing $\mathrm{NO}_{\mathrm{x}} \ldots \ldots . .6 .6$

6.13. Calculated Thermodynamic Values for Fluorination of $\mathrm{K}_{2} \mathrm{O}$ by $\mathrm{NF}_{3}$ and $\mathrm{HF}$....................6.7

6.14. Calculated Thermodynamic Values for Fluorination of $\mathrm{K}_{2} \mathrm{O}$ by $\mathrm{NF}_{3}$ Producing $\mathrm{NO}_{\mathrm{x}} \ldots \ldots \ldots . . .6 .7$

6.15. Calculated Thermodynamic Values for Fluorination of $\mathrm{KOH}$ by $\mathrm{NF}_{3}$ and $\mathrm{HF}$...................6.7

6.16. Calculated Thermodynamic Values for Fluorination of $\mathrm{KOH}$ by $\mathrm{NF}_{3}$ Producing $\mathrm{NO}_{\mathrm{x}} \ldots \ldots \ldots . .6 .8$

6.17. Calculated Thermodynamic Values for Fluorination of $\mathrm{ZrO}_{2}$ by $\mathrm{NF}_{3}$ and $\mathrm{HF}$...................6.8 
6.18. Calculated Thermodynamic Values for Fluorination of $\mathrm{ZrO}_{2}$ by $\mathrm{NF}_{3}$ Producing $\mathrm{NO}_{\mathrm{x}} \ldots \ldots \ldots . .6 .9$

6.19. Calculated Thermodynamic Values for Fluorination of $\mathrm{Zr}(\mathrm{OH})_{4}$ by $\mathrm{NF}_{3}$ and $\mathrm{HF}$

6.20. Calculated Thermodynamic Values for Fluorination of $\mathrm{Zr}(\mathrm{OH})_{2}$ by $\mathrm{NF}_{3}$ Producing $\mathrm{NO}_{\mathrm{x}}$....6.9

6.21. Calculated Thermodynamic Values for Fluorination of $\mathrm{KBO}_{2}$ by $\mathrm{NF}_{3}$ and $\mathrm{HF}$

6.22. Calculated Thermodynamic Values for Fluorination of $\mathrm{KBO}_{2}$ by $\mathrm{NF}_{3}$ Producing $\mathrm{NO}_{\mathbf{x}} \ldots \ldots .6 .10$

6.23. Calculated Thermodynamic Values for Fluorination of $\mathrm{RbOH}_{\text {by }} \mathrm{NF}_{3}$ and $\mathrm{HF}$

6.24. Calculated Thermodynamic Values for Fluorination of $\mathrm{RbOH}$ by $\mathrm{NF}_{3}$ Producing $\mathrm{NO}_{\mathrm{x}} \ldots . .6 .11$

6.25. Calculated Thermodynamic Values for Fluorination of $\mathrm{Rb}_{2} \mathrm{O}$ by $\mathrm{NF}_{3}$ and $\mathrm{HF}$ 6.12

6.26. Calculated Thermodynamic Values for Fluorination of $\mathrm{Rb}_{2} \mathrm{O}$ by $\mathrm{NF}_{3}$ Producing $\mathrm{NO}_{\mathrm{x}} \ldots \ldots . .6 .12$

6.27. Calculated Thermodynamic Values for Fluorination of $\mathrm{C}$ by $\mathrm{NF}_{3}$ and $\mathrm{HF}$

6.28. Calculated Thermodynamic Values for Fluorination of $\mathrm{SiC}$ by $\mathrm{NF}_{3}$ and $\mathrm{HF}$ 6.13

6.29. Calculated Thermodynamic Values for Fluorination of $\mathrm{UO}_{2}$ by $\mathrm{NF}_{3}$ and $\mathrm{HF}$ 6.14

6.30. Calculated Thermodynamic Values for Fluorination of $\mathrm{UO}_{2}$ by $\mathrm{NF}_{3}$ Producing $\mathrm{NO}_{\mathbf{x}}$ 6.14 


\subsection{Introduction}

With the resurgence of nuclear power as a potentially attractive source of energy, the interest in molten salt cooled reactors has also been renewed with its inclusion as one of the six Generation IV reactor types (U.S. DOE Nuclear Energy Research Advisory Committee and Generation IV International Forum 2002) (Figure 1.1).

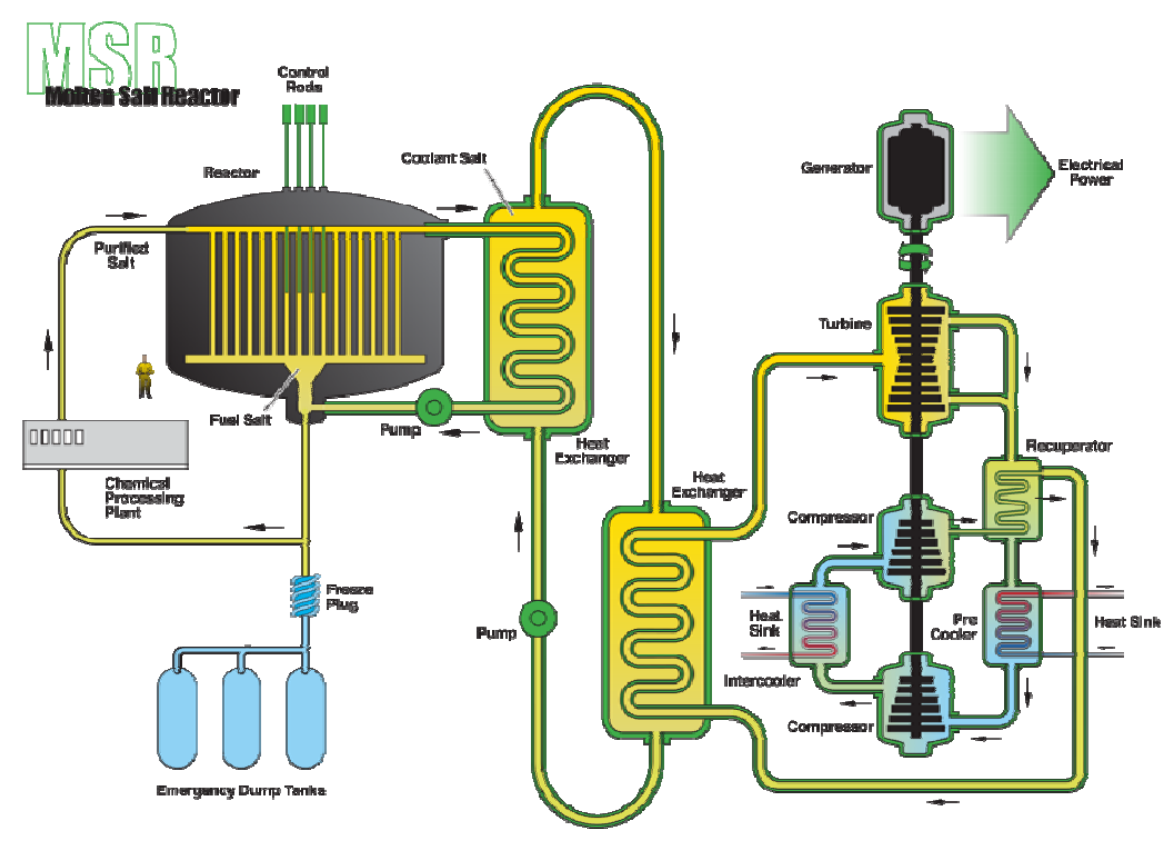

Figure 1.1. Schematic of Molten Salt Reactor (U.S. DOE Nuclear Energy Research Advisory Committee and Generation IV International Forum 2002)

As part of the U.S. Department of Energy's (DOE's) program to develop the next generation nuclear reactor, the Oak Ridge National Laboratory (ORNL) is preparing for the construction and operation of a fluoride salt-cooled high temperature reactor (FHR). Towards this goal, ORNL is formulating plans and identifying what component testing is required for an FHR test system (FHR-TS) (Holcomb et al. 2009). Holcomb et al. state "The reactor conceptual design is primarily derived from the most recent University of California at Berkeley FHR-16 test reactor design overview documents and the slightly older ORNL prismatic block fuel Advanced High-Temperature Reactor development program reports."

A drawing of the University of California at Berkeley's proposed pebble-bed FHR power plant is provided in Figure 1.2. The reactor is cooled by a primary liquid fluoride salt coolant. The heat in the primary coolant is transferred to a secondary molten fluoride salt. The heat in the secondary coolant is converted to electricity by a closed-loop Brayton electricity generation cycle. Figure 1.3 provides a schematic of the primary heat-transfer flow for the FHR-TS that includes the location of the Direct Reactor Auxiliary Cooling System (DRACS). The DRACS will use a liquid fluoride salt as the primary means for removing decay heat from the reactor in the event that the primary and shutdown cooling systems fail. 
One of Holcomb et al.'s (2009) concerns is removing and maintaining the purity of the primary coolant ${ }^{7} \mathrm{LiFBeF}_{2}$ (flibe) and the secondary coolants. Flibe has limited availability because of the need for enriched ${ }^{7} \mathrm{Li}$. Although when pure, high-purity fluoride salts have low corrosivity, when contaminated by water or oxygen their corrosivity increases significantly and can corrode and compromise the containment. Thus an approach is needed for removing oxygen and water, and potentially other contaminants from the coolant salts. Other potential contaminants include corrosion products from the materials of construction, graphite fines, neutron activation products, and broken fuel spheres.

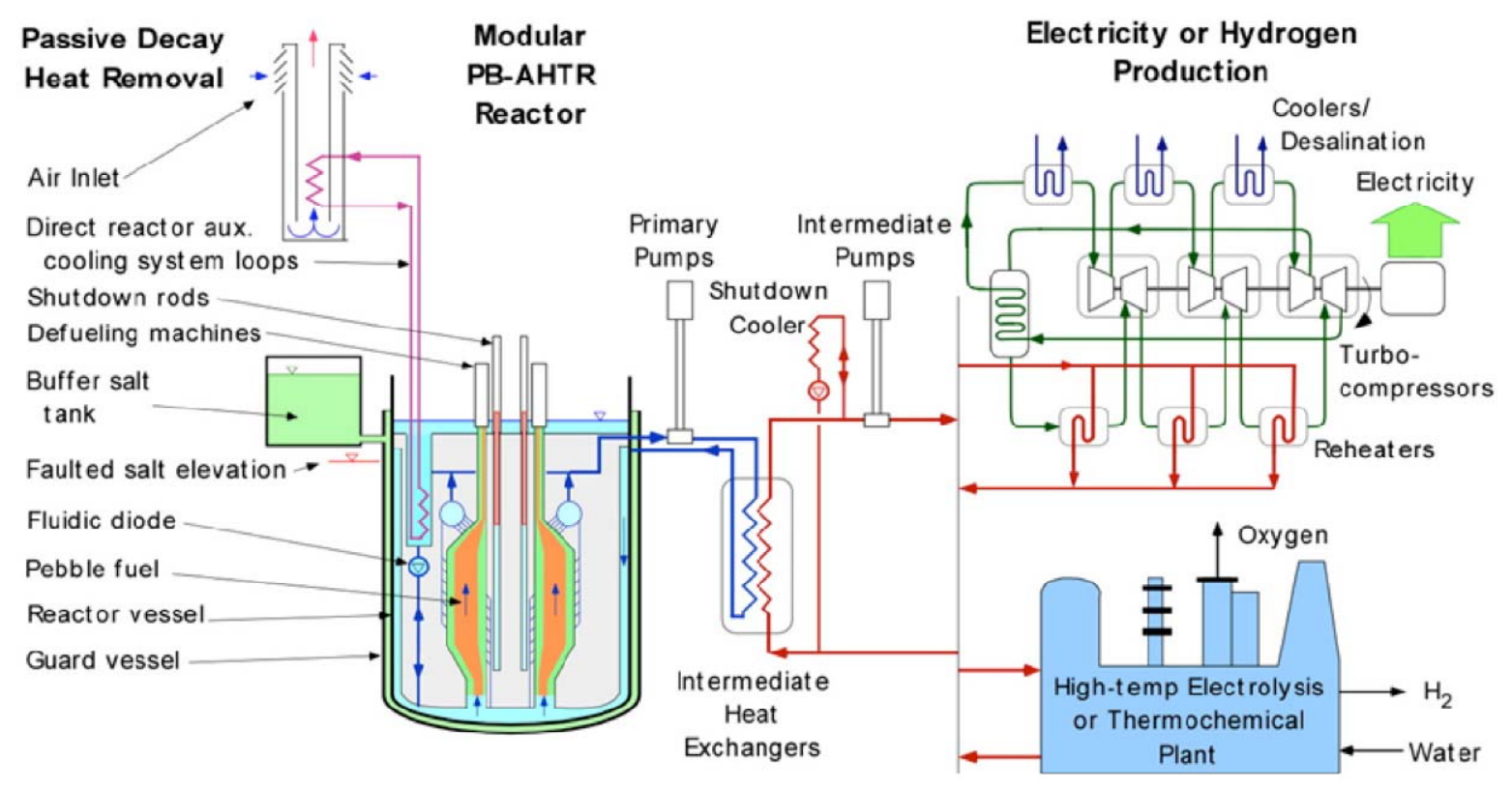

Figure 1.2. Conceptual Drawing of a Pebble Bed FHR and Power Generation Cycle (Holcomb et al. 2009)

Holcomb et al.'s (2009) strategy to reduce the coolant's corrosive properties is to divert and treat a side-stream flow with a hydrogen fluoride/hydrogen $\left(\mathrm{HF} / \mathrm{H}_{2}\right)$ or nitrogen trifluoride $\left(\mathrm{NF}_{3}\right)$ purge to remove oxygen contamination. The former is the traditional approach for salt purification (Shaffer 1971). Holcomb et al. describe the process as bubbling the fluorinating gases through the salt to replace the oxygen with fluorine and convert the oxygen to water vapor with the hydrogen. The free fluorine potential is managed by passing the salt over a bare beryllium metal surface. The other contaminants such as graphite dust and broken fuel pebble pieces are removed by mechanical filtration. Holcomb et al. had not determined the approach or whether there was a need to remove graphite impurities from the primary coolant.

In support of DOE's and ORNL's efforts to develop an advanced molten salt-cooled reactor, we at the Pacific Northwest National Laboratory (PNNL) are assessing $\mathrm{NF}_{3}$ use to remove water, hydroxide, and oxygen contaminants from the coolants. In this report we provide comparative information for $\mathrm{NF}_{3}$ and $\mathrm{HF}$, including physical properties, costs, availability, and the thermodynamics for reactions with potential oxide and hydroxide contaminants. In addition to the use of $\mathrm{NF}_{3}$ to remove oxygen and water impurities from the molten fluoride coolants, we use thermodynamic calculations to investigate potential use of $\mathrm{NF}_{3}$ to treat other contaminants such as carbon, silicon carbide, and uranium dioxide that could arise from broken fuel. 


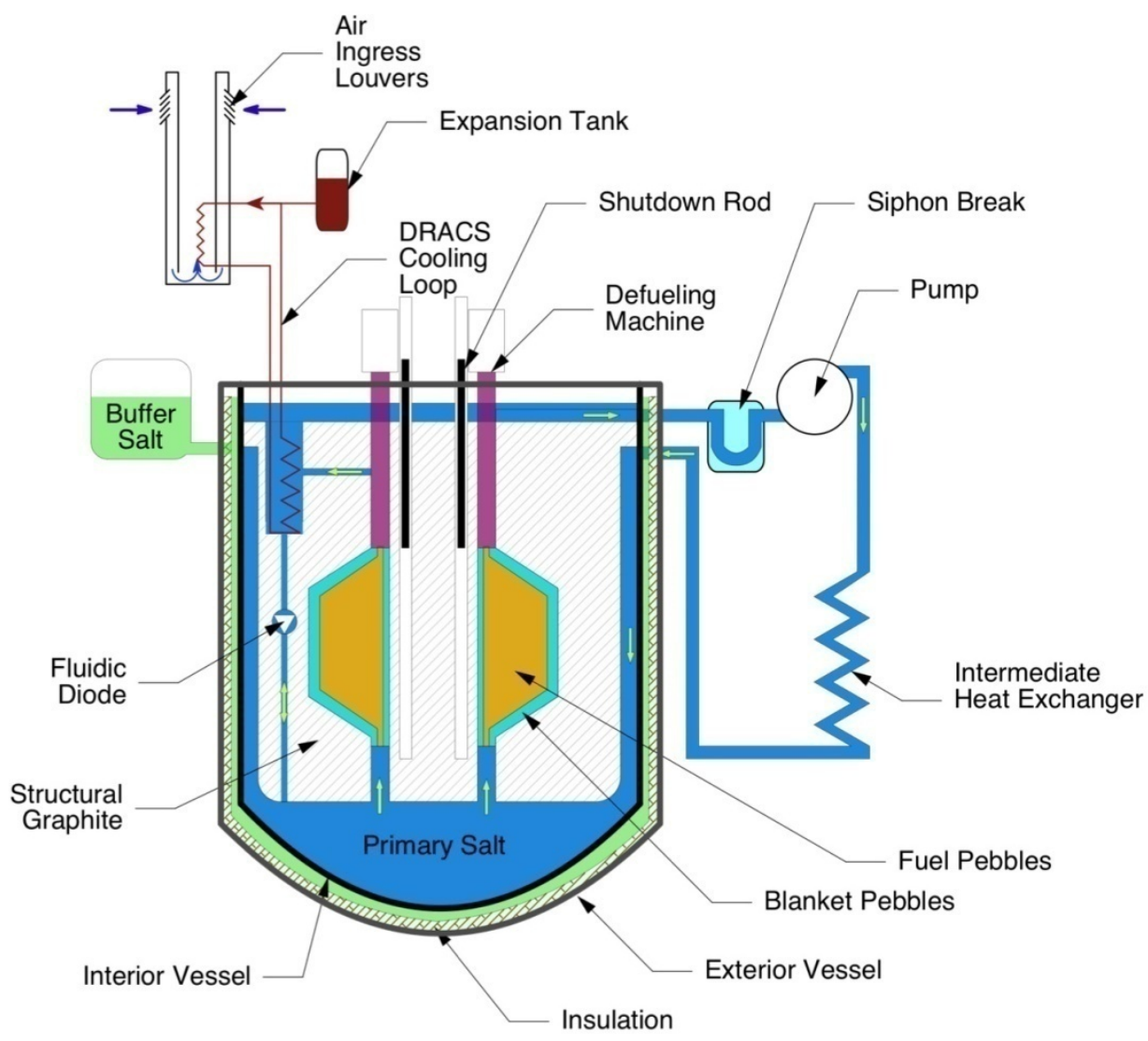

Figure 1.3. Overall FHR-TS Primary Heat Transfer Flow (Holcomb et al. 2009)

The ensuing sections of this report describe candidate coolant and heat-transfer salts for FHR-TS, the properties of $\mathrm{NF}_{3}$ and $\mathrm{HF}$, factors to be considered in designing the associated purification process, reported use of $\mathrm{NF}_{3}$ and $\mathrm{HF}$ as purification agents, the thermodynamics of $\mathrm{NF}_{3}$ and $\mathrm{HF}$ purification of molten salt reactor (MSR) coolant and secondary heat-transfer salts, and financial considerations associated with the use of $\mathrm{NF}_{3}$ and $\mathrm{HF}$. Conclusions and references are provided in the final two sections. 



\subsection{Candidate Coolant and Heat-Transfer Salts for FHR-TS}

The baseline primary coolant for the FHR-TS is $66 \mathrm{~mol} \%{ }^{7} \mathrm{LiF}$ and $33 \mathrm{~mol} \% \mathrm{BeF}_{2}$ or flibe (Holcomb et al. 2009). The leading intermediate coolant candidates for the FHR-TS are $\mathrm{KF}_{-} \mathrm{ZrF}_{4}, \mathrm{KF}_{-} \mathrm{KBF}_{4}$, and LiF-NaF-KF (flinak) (Holcomb et al. 2009). The leading candidate materials for the DRACS coolingloop coolant are lower melting point fluoride salts such as $\mathrm{KF}-\mathrm{ZrF}{ }_{4}, \mathrm{KF}_{-} \mathrm{KBF}_{4}$, and ${ }^{7} \mathrm{LiNaBeF}_{4}$.

Contaminants can arise in these fluoride salts through hydrolysis and oxidation reactions with environmental or tramp $\mathrm{O}_{2}$ or $\mathrm{H}_{2} \mathrm{O}$. The likely contaminants are oxides or hydroxides of the constituent fluoride salts and/or hydrated salts.

\subsection{Contaminants in Coolant and Heat-Transfer Salts}

Mathews and Baes (1968) found that water reacts with fluoride ion in flibe to form dissolved $\mathrm{O}^{2-}$ and $\mathrm{OH}^{-}$and $\mathrm{HF}$ in accordance with Equation (2.1) and Equation (2.2). With a solubility of 0.01 mole beryllium oxide $(\mathrm{BeO}) / \mathrm{kg}$ flibe, solid beryllium oxide $\mathrm{BeO}$ will form (Mathews and Baes 1968) per Equation (2.3). $\mathrm{BeF}_{2}$ is hygroscopic (Everest 1973) making control of exposure to water critical for preventing corrosive constituents from being introduced into the flibe and other fluoride salts used in the molten salt reactor. Fortunately LiF is not hygroscopic (Hart and Beumel 1973).

$$
\begin{aligned}
& \mathrm{H}_{2} \mathrm{O}_{(g)}+2 F_{(d)}^{-} \rightarrow O_{(d)}^{2-}+2 H F_{(g)}
\end{aligned}
$$

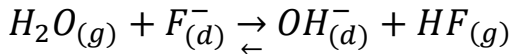

$$
\begin{aligned}
& \mathrm{H}_{2} \mathrm{O}_{(g)}+\mathrm{BeF}_{2(d)} \underset{\leftarrow}{\mathrm{BeO}}(\mathrm{c})+2 \mathrm{HF}_{(g)}
\end{aligned}
$$

where $g$ refers to the gaseous state, $d$ refers to a solute, and $c$ refers to the solid state.

Our thermodynamic equilibrium calculations using HSC Chemistry (Roine et al. 2009) for flibe exposed to $\mathrm{H}_{2} \mathrm{O} / \mathrm{O}_{2}$ and $\mathrm{H}_{2} \mathrm{O}$ alone as provided in Figure 2.1 and Figure 2.2 also indicate that the $\mathrm{H}_{2} \mathrm{O}$ will convert a portion of $\mathrm{BeF}_{2}$ to $\mathrm{BeO}$ and $\mathrm{HF}$; the calculations use 1 mole of $\mathrm{H}_{2} \mathrm{O}$ and/or 1 mole of $\mathrm{O}_{2}$ per mole of flibe. At $800^{\circ} \mathrm{C}$ nominally $16 \%$ of the $\mathrm{BeF}_{2}$ will be converted to $\mathrm{BeO}$ when both $\mathrm{H}_{2} \mathrm{O}$ and $\mathrm{O}_{2}$ are present and $12 \%$ when only $\mathrm{H}_{2} \mathrm{O}$ is present. Thus, water has the predominant influence on the conversion of the $\mathrm{BeF}_{2}$ to $\mathrm{BeO}$ but $\mathrm{O}_{2}$ also has a significant effect. The equilibrium amount of $\mathrm{BeO}$ increases with increasing temperature. These figures also illustrate the complex nature of $\mathrm{F}, \mathrm{Li}$, and $\mathrm{Be}$ in flibe as a function of temperature.

The work of Mathews and Baes (1968) and our equilibrium thermodynamic calculations also illustrate why $\mathrm{HF}$ is effective at converting $\mathrm{BeO}$ back to $\mathrm{BeF}_{2}$. $\mathrm{HF}$ treatment of flibe and other fluoride salts contaminated with oxygen simply shifts the equilibrium to favor water formation rather than $\mathrm{BeO}$.

The impact of $\mathrm{H}_{2} \mathrm{O} / \mathrm{O}_{2}$ and $\mathrm{H}_{2} \mathrm{O}$ alone on the composition of flinak (LiF-NaF-KF: 46.5-11.5-42 mol\%) is illustrated in Figure 2.3 and Figure 2.4. These figures show that when 1 mole of flinak is treated with $1 \mathrm{~mol} \mathrm{H}_{2} \mathrm{O}$ and/or $1 \mathrm{~mol} \mathrm{O}_{2}$ the conversion of the constituent fluoride salts to their oxide or hydroxide is less than $10 \mathrm{~mol} \mathrm{ppm}$. We performed similar calculations to determine how exposure to water would affect various salt constituents. Of these constituents, only $\mathrm{ZrF}_{4}$ would be converted to $\mathrm{ZrO}_{2}$ in any significant quantity. For evaluation purposes, we assume that the constituent fluoride salts form their respective oxides and hydroxides. 


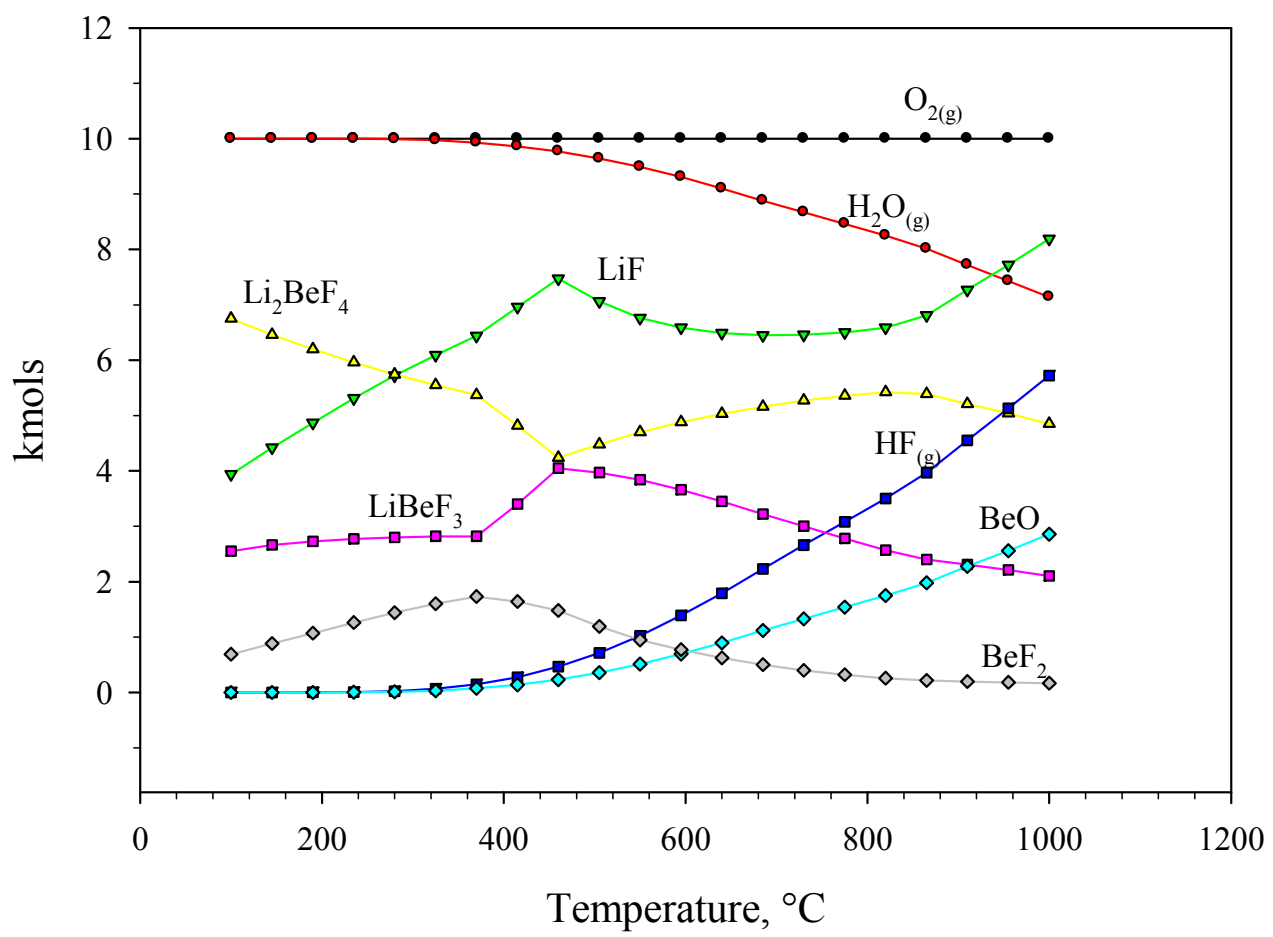

Figure 2.1. Predicted Equilibrium Composition for Flibe Exposed to $\mathrm{H}_{2} \mathrm{O} / \mathrm{O}_{2}$ (1 $\mathrm{mol} \mathrm{H}_{2} \mathrm{O}: 1 \mathrm{~mol} \mathrm{O}_{2}: 1 \mathrm{~mol}$ flibe)

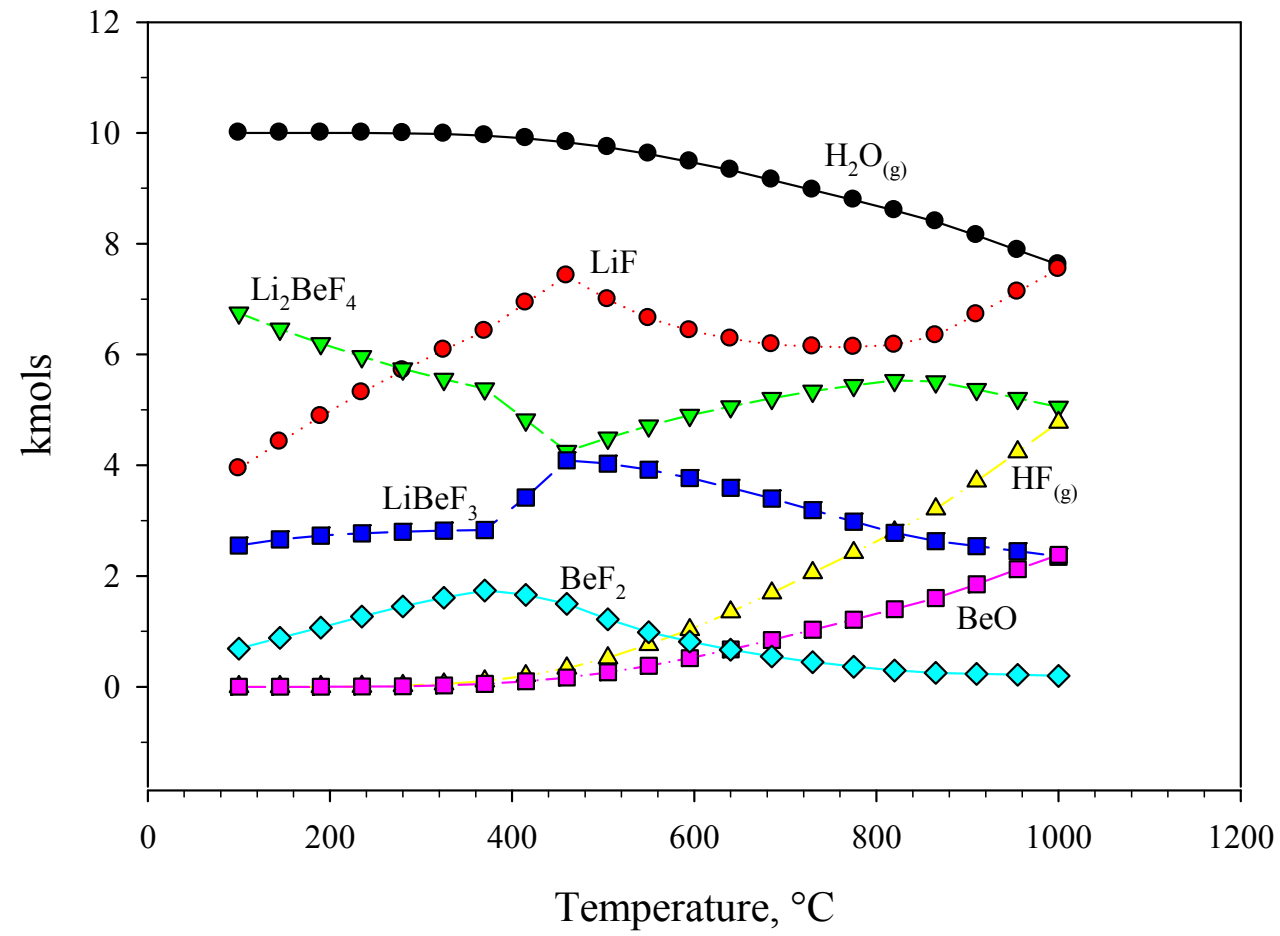

Figure 2.2. Predicted Equilibrium Composition for Flibe Exposed to $\mathrm{H}_{2} \mathrm{O}$ ( $1 \mathrm{~mol} \mathrm{H}_{2} \mathrm{O}: 1$ mol flibe) 


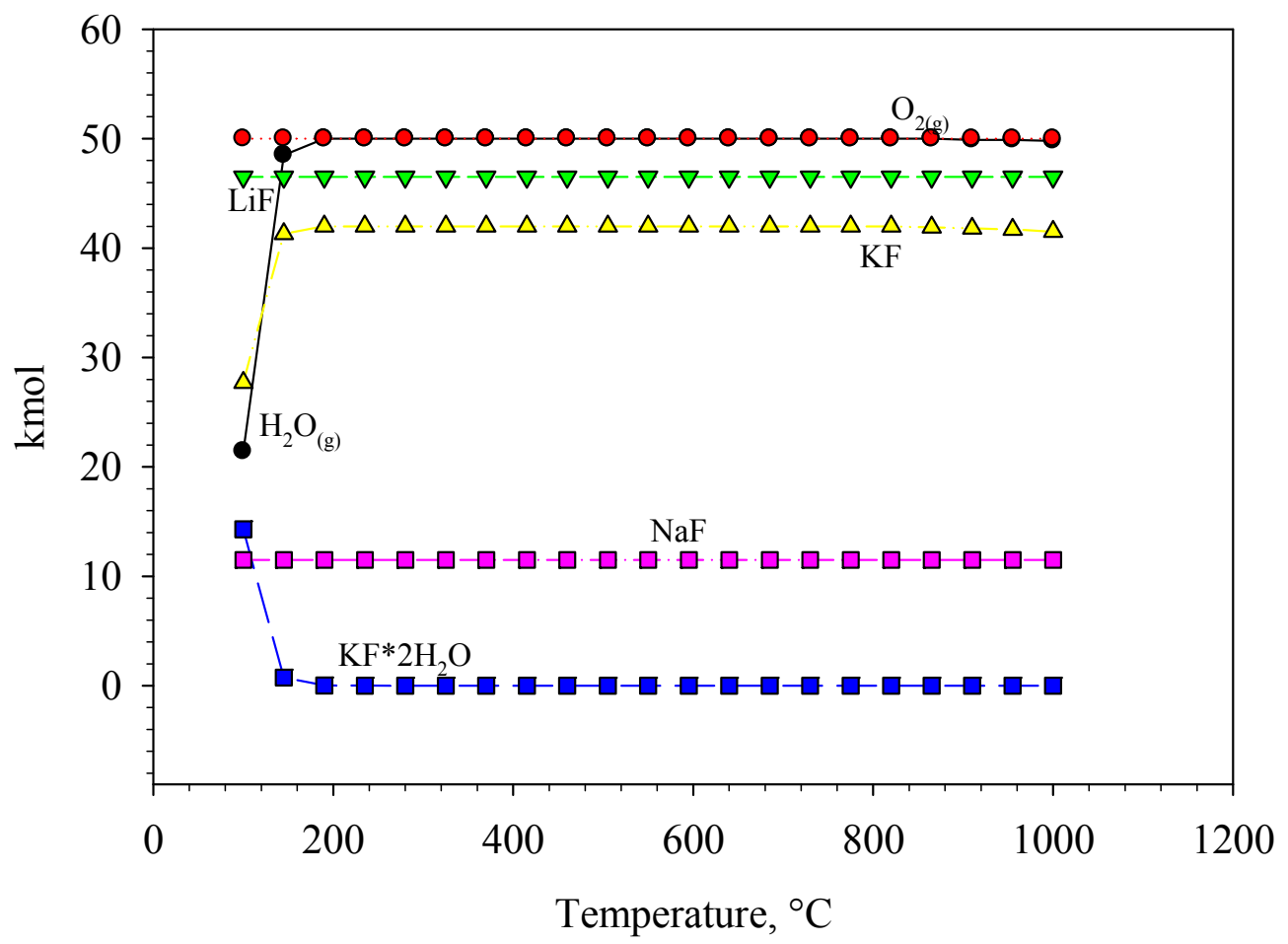

Figure 2.3. Predicted Equilibrium Composition for Flinak Exposed to $\mathrm{H}_{2} \mathrm{O} / \mathrm{O}_{2}\left(1 \mathrm{~mol} \mathrm{H}_{2} \mathrm{O}: 1 \mathrm{~mol}\right.$ $\mathrm{O}_{2}: 2$ mol flinak)

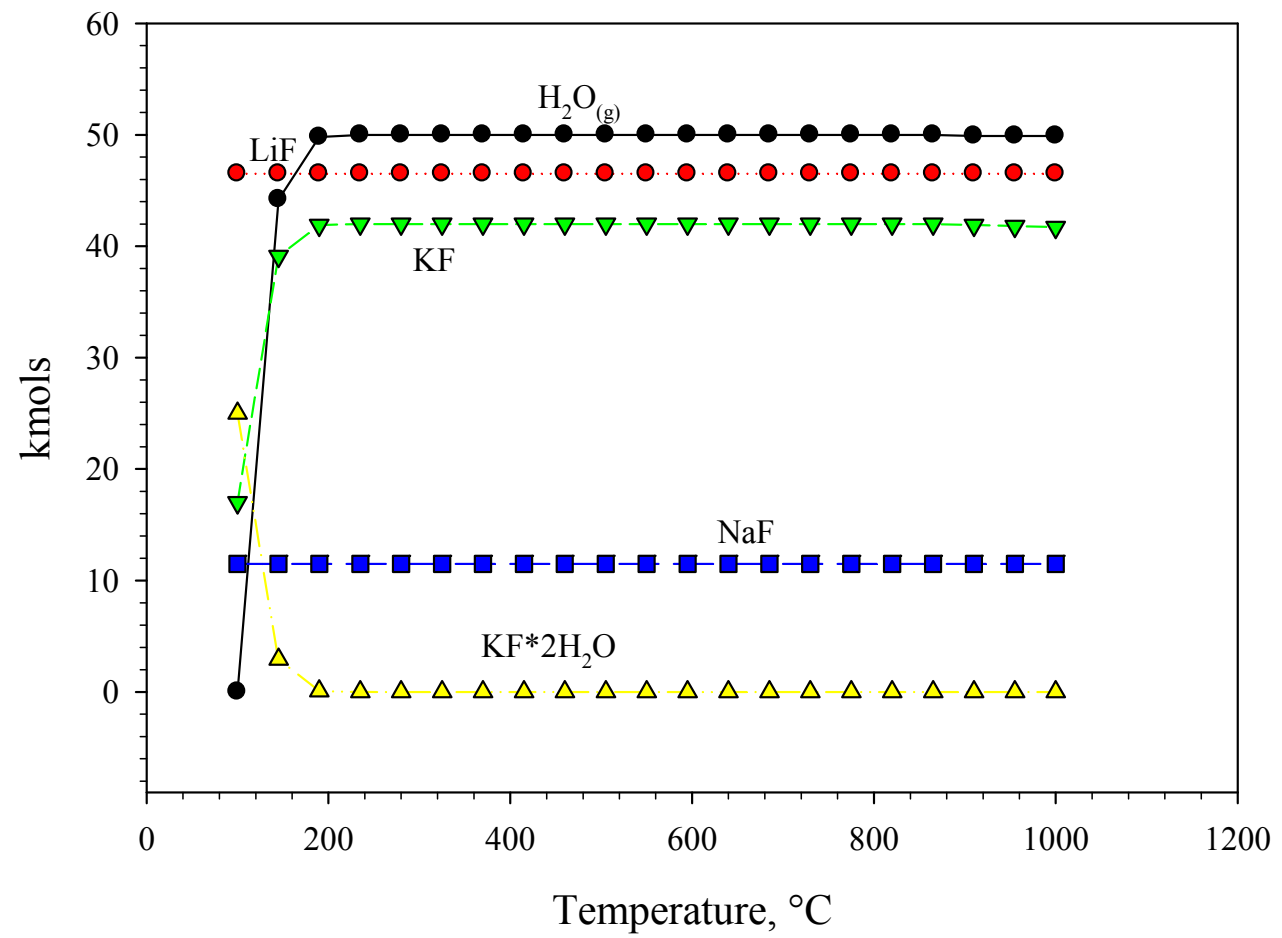

Figure 2.4. Predicted Equilibrium Composition for Flinak Exposed to $\mathrm{H}_{2} \mathrm{O}\left(1 \mathrm{~mol} \mathrm{H}_{2} \mathrm{O}: 2 \mathrm{~mol}\right.$ flinak) 


\subsection{Coolant and Heat Transfer Salts Properties}

Several of the coolant and heat transfer salts physical properties will be important during purification processing. Of these the melting point is of particular importance for this report since our thermodynamic calculations are dependent on temperature. In their evaluation of candidate coolant salts, Williams et al. (2006) and Williams (2006) provide the melting point, $900^{\circ} \mathrm{C}$ vapor pressure, and at $700^{\circ} \mathrm{C}$ the density, volumetric heat capacity, viscosity, and thermal conductivity of all the candidate fluoride coolants with the exception of $\mathrm{KF}_{-} \mathrm{KBOF}_{4}$. Table 2.1 provides the melting points of the candidate coolant salts (Holcomb et al. 2009) plus that of LiF-NaF-RbF reported by Williams et al. and Williams.

Table 2.1. Melting Points of Candidate Primary, Intermediate, and DRACS Coolant Salts (Williams et al. 2006; Williams 2006)

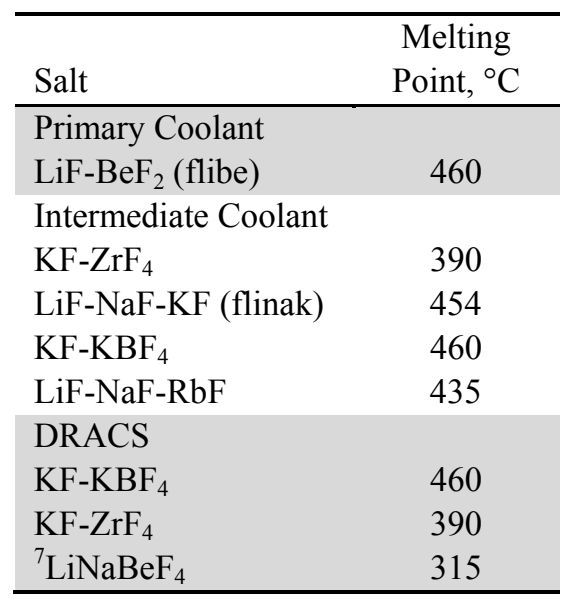




\section{0 $\mathrm{NF}_{3}$ and HF Properties and Use Considerations}

In this section we provide and discuss factors that should be considered in designing the process for purifying the fluoride coolant salts using $\mathrm{HF}$ and $\mathrm{NF}_{3}$. In this section we include $\mathrm{HF}$ and $\mathrm{NF}_{3}$ industrial use, chemical and physical properties, production levels, chemical and reactivity hazards, environmental impacts, and effluent management strategies.

\subsection{HF Background}

Smith (2010) describes HF as the most important manufactured fluorine compound because it is produced in the largest volume and it serves as the precursor for almost all other fluorine-containing chemicals. Its early use was for etching glass; removing foundry scale; producing chemicals such as sodium fluoride and bifluoride; aluminum manufacture; and producing chlorofluorocarbons. Current uses include the production of fluorocarbons, uranium tetrafluoride as a precursor of uranium hexafluoride, petroleum alkylation to produce high octane fuels, organic and inorganic fluorides, aluminum, and a variety of chemical treatments such as stainless steel pickling, chemical milling, exotic metals extraction, and quartz purification.

\section{2 $\mathrm{NF}_{3}$ Background}

$\mathrm{NF}_{3}$ is an industrially important oxidizing and fluorinating agent used in the electronics industry as a silicon etchant, as a thermal agent for removing residual coatings deposited in chemical vapor deposition (CVD) reactors as volatile fluorides, and as a fluorine source in high power chemical lasers. At one time it was considered for use as a rocket propellant. In the mid $1990 \mathrm{~s}, \mathrm{NF}_{3}$ replaced perfluorocarbons compounds such as tetrafluoromethane $\left(\mathrm{CF}_{4}\right)$, hexafluoroethane $\left(\mathrm{C}_{2} \mathrm{~F}_{6}\right)$, and sulfur hexafluoride as the silicon-etching and CVD reactor-cleaning agents for the electronics industry to reach Kyoto Protocol goals for reducing these gases (Tsai 2008) because it was considered to be an environmentally benign material. Recent evaluations (Prather and Hsu 2008; Tsai 2008) identify $\mathrm{NF}_{3}$ as a potential significant long-lived "greenhouse" gas.

\subsection{HF Production and Delivery}

According to Smith (2010), the predominant method for producing HF worldwide is the action of sulfuric acid $\left(\mathrm{H}_{2} \mathrm{SO}_{4}\right)$ on fluorspar $\left(\mathrm{CaF}_{2}\right)$ per the endothermic reaction

$$
\mathrm{CaF}_{2(\mathrm{~s})}+\mathrm{H}_{2} \mathrm{SO}_{4} \stackrel{\Delta}{\rightarrow} \mathrm{CaSO}_{4(\mathrm{~s})}+2 \mathrm{HF}
$$

which is typically performed at $200^{\circ} \mathrm{C}$ in a rotating kiln (HSC Chemistry [Roine 2009] calculates the $\Delta \mathrm{H}$ and $\Delta \mathrm{G}$ to be $52 \mathrm{~kJ}$ and $-45 \mathrm{~kJ}$, respectively). The gaseous $\mathrm{HF}$ product is condensed with refrigerant and further purified by distillation. The vent gases are scrubbed with incoming $\mathrm{H}_{2} \mathrm{SO}_{4}$ to remove the bulk of the HF. The plant exhaust gas is finally scrubbed with water or aqueous alkali. In North America, Smith (2010) indicates that the production capacity of HF is 434,000 tons with a 2005 projected demand of 364,000 tons. 
Anhydrous HF is delivered in tank cars (specification 112S400W), tank trucks (specification MC312), and in gas cylinders. The tank cars and trucks are carbon steel.

\subsubsection{HF Chemical Specifications}

Anhydrous HF is provided with a $99.95 \%$ purity as listed in Table 3.1. The contaminants are nonvolatile acids, sulfur dioxide $\left(\mathrm{SO}_{2}\right)$, water, arsenic, and fluorosilicic acid.

Table 3.1. Hydrogen Fluoride Product Specifications (Smith 2010)

\begin{tabular}{lc}
\hline Component & Specification \\
\hline HF, wt $\%$ & 99.95 \\
Nonvolatile acid, ppm & 100 \\
Sulfur dioxide, ppm & 50 \\
Water, ppm & 200 \\
Arsenic, ppm & 25 \\
Fluosilicic acid & 100 \\
\hline
\end{tabular}

\subsection{Nitrogen Trifluoride Production and Delivery}

Although a variety of methods are available for producing $\mathrm{NF}_{3}$, the two primary large- or industrialscale methods use either direct fluorination of ammonia (Equation [3.2]) or electrolysis of molten ammonium acid fluoride (Equation [3.3]) (Klapötke 2006; Katsuhara et al. 2006; Technical Resources International 2001; Henderson and Woytek 2010). Central Glass Company, Ltd developed and uses an alternative process using elemental fluorine to fluorinate ammonium cryolite (Katsuhara et al. 2006).

Air Products and Chemicals, Inc. (Air Products) implementation of Tompkins and Wang's method (1966) electrochemically converts molten ammonium acid fluoride to $\mathrm{NF}_{3}$ using $\mathrm{HF}$ per Equation (3.2) (Katsuhara et al. 2006; Klapötke 2006). The second major industrial method used by Air Products uses direct fluorination of ammonia over heated ammonium acid fluoride using elemental fluorine (Woytek and Lileck 1978) per Equation (3.3) (Katsuhara et al. 2006; Klapötke 2006). Central Glass Co. Ltd's alternative process is described by Equation (3.4) (Katsuhara et al. 2006).

$$
\begin{aligned}
& \mathrm{NH}_{3}+3 \mathrm{HF} \underset{\mathrm{NH}}{\stackrel{6 \mathrm{H}^{-}}{\stackrel{\mathrm{FHF}}{\longrightarrow}}} \mathrm{NF} \mathrm{F}_{3}+3 \mathrm{H}_{2} \\
& \Delta\left(130-150^{\circ} \mathrm{C}\right)
\end{aligned}
$$

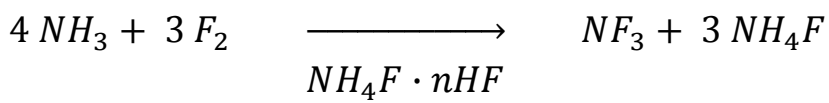

$$
\begin{aligned}
& \Delta\left(150^{\circ} \mathrm{C}\right) \\
& \left(\mathrm{NH}_{4}\right)_{3} \mathrm{AlF}_{6}+6 \mathrm{~F}_{2} \longrightarrow 2 \mathrm{NF}_{3}+8 \mathrm{HF}+\mathrm{NH}_{4} \mathrm{AlF}_{4}
\end{aligned}
$$




\subsection{1 $\quad \mathrm{NF}_{3}$ Production Levels}

Information about the total $\mathrm{NF}_{3}$ production levels and capacity is not freely available, but, based on Prather and Hsu's (2008) estimates, the total 2008 production was 4,000 $\pm 25 \%$ tons; Prather and Hsu estimate that the amount produced will be double that in 2010. Air Products, the largest producermanufacturer of $\mathrm{NF}_{3}$, was planning to produce 3,200 tons by 2009 (Air Products 2007). In July 2005

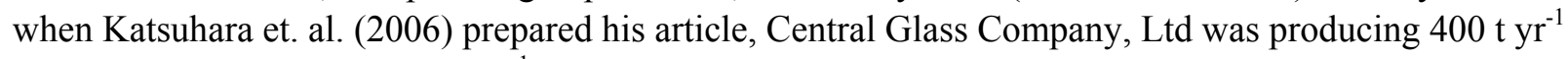
and had plans to produce $600 \mathrm{t} \mathrm{yr}^{-1}$ by the end of 2006 by direct fluorination of cyrolite with $\mathrm{F}_{2}$. Other producers include Kanto Denka at 1,000 ton $\mathrm{yr}^{-1}$, DuPont in China, Formosa Plastics, Mitsui Chemicals, and Anderson Development Co. (Technical Resources International 2001; Prather and Hsu 2008); Technical Resources International (2001) expected Advanced Specialty Gases to resume production.

Air Products supplies $\mathrm{NF}_{3}$ in three grades: commercial (99.7\% Purity), VLSI (99.9\% Purity), and Megaclass (99.996\% Purity). Central Glass Company, Ltd. provides 99.995\% Purity $\mathrm{NF}_{3}$. The permissible impurity levels for these three classes are provided in Table 3.2. Air Products purifies $\mathrm{NF}_{3}$ at the high-purity levels required by the electronics industry by removing $\mathrm{N}_{2} \mathrm{~F}_{2}$ by pyrolysis over 200 to $300^{\circ} \mathrm{C}(473$ to $573 \mathrm{~K})$ metal or metal fluoride (Henderson and Woytek 2010). These temperatures are below the temperature at which $\mathrm{NF}_{3}$ is converted to $\mathrm{N}_{2} \mathrm{~F}_{4}$. Water, nitrous oxide $\left(\mathrm{N}_{2} \mathrm{O}\right)$, and carbon dioxide $\left(\mathrm{CO}_{2}\right)$ are removed by adsorption on zeolites (Henderson and Woytek 2010).

Table 3.2. Air Products and Chemicals Commercial Grades of $\mathrm{NF}_{3}$ (Henderson and Woytek 2010)

\begin{tabular}{lccc}
\hline \multicolumn{1}{c}{ Impurity } & $\begin{array}{c}\text { Commercial } \\
(99.7 \% \text { Purity), vppm }\end{array}$ & $\begin{array}{c}\text { VLSI } \\
(99.9 \% \text { Purity }), \text { vppm }\end{array}$ & $\begin{array}{c}\text { Megaclass } \\
(99.996 \% \text { Purity }), \text { vppm }\end{array}$ \\
\hline Total fluorides as HF & 3,900 & 1 & 1 \\
$\mathrm{CO}_{2}$ & 130 & 16 & 4 \\
$\mathrm{CO}$ & 330 & 25 & 0.5 \\
$\mathrm{CF}_{4}$ & 1,200 & 560 & 25 \\
$\mathrm{~N}_{2}$ & 19,000 & 130 & 10 \\
$\mathrm{O}_{2}+\mathrm{Ar}$ & 22,000 & 100 & 6 \\
$\mathrm{SF}_{6}$ & 50 & 25 & 1 \\
$\mathrm{~N}_{2} \mathrm{O}$ & 500 & 16 & 2 \\
$\mathrm{H}_{2} \mathrm{O}$ & 1 & 1 & 1 \\
\hline
\end{tabular}

\subsection{2 $\mathrm{NF}_{3}$ Delivery}

Air Products delivers $\mathrm{NF}_{3}$ in high-pressure cylinders or bulk containers. The high pressure cylinders are pressurized to $10 \mathrm{MPa}\left(1450 \mathrm{psig}\right.$ ) (Henderson and Woytek 2010). $\mathrm{NF}_{3}$ is also available in large skidmounted containers (Y-cylinders) that contain $195 \mathrm{~kg}(430 \mathrm{lb})$ and are mounted horizontally and are tapered and threaded at both ends (Air Products 2010a). Large amounts of $\mathrm{NF}_{3}$ can be delivered in tube trailers or ISO modules that are most commonly four or eight tube bundles of 56-cm (22-in.) diameter tubes containing up to $5,440 \mathrm{~kg}(12,000 \mathrm{lb})$.

\subsection{Nitrogen Trifluoride Chemical and Physical Properties}

$\mathrm{NF}_{3}$ is a colorless gas at room temperature that boils at $-128.75^{\circ} \mathrm{C}(144.40 \mathrm{~K}) . \mathrm{NF}_{3}$ has a pyramidal structure with $\mathrm{C}_{3 v}$ point group symmetry, which is similar to ammonia $\left(\mathrm{NH}_{3}\right)$. However, in contrast to 
ammonia, $\mathrm{NF}_{3}$ exhibits no basic properties (Gillespie and Pez 1969) and is not protonated even in the super-acid $\mathrm{HSO}_{3} \mathrm{~F}-\mathrm{SbF}_{5}-\mathrm{SO}_{3}$. If of high purity, $\mathrm{NF}_{3}$ has little odor but it can have a pungent, musty odor if it is contaminated with traces of active fluorides.

Table 3.3 provides a selection of $\mathrm{NF}_{3}$ 's physico-chemical properties. Anderson et al. (1977) provides a broad based general reference for $\mathrm{NF}_{3}$ but has limited distribution and thus is not referenced here.

Table 3.3. Selected Physical Properties of $\mathrm{NF}_{3}$

\begin{tabular}{|c|c|c|}
\hline Property & Value & Reference \\
\hline Molecular mass, $\mathrm{g} \mathrm{mol}^{-1}$ & 71.002 & (Patnaik 2003) \\
\hline Melting point, ${ }^{\circ} \mathrm{C}(\mathrm{K})$ & $-206.8(66.4)$ & (Patnaik 2003) \\
\hline Boiling point, ${ }^{\circ} \mathrm{C}(\mathrm{K})$ & $-128.75(144.40)$ & (Patnaik 2003) \\
\hline Liquid density at $-128.75^{\circ} \mathrm{C}(144.40 \mathrm{~K}), \mathrm{kg} \mathrm{m}^{-3}$ & 1.533 & (Henderson and Woytek 2010) \\
\hline Gas density at $101.3 \mathrm{kPa}(1 \mathrm{~atm}) 21^{\circ} \mathrm{C}(294 \mathrm{~K}), \mathrm{kg} \mathrm{m}^{-3}$ & 2.902 & (Lide 2010) \\
\hline Specific gravity at $101.3 \mathrm{kPa}(1 \mathrm{~atm}) 21.1^{\circ} \mathrm{C}(294.2 \mathrm{~K})$ & $2.46($ air $=1)$ & $\begin{array}{l}\text { (Technical Resources } \\
\text { International 2001) }\end{array}$ \\
\hline Heat of vaporization, $\mathrm{kJ} \mathrm{mol}^{-1}$ & 11.59 & (Henderson and Woytek 2010) \\
\hline Triple point, ${ }^{\circ} \mathrm{C}(\mathrm{K}) 0.263 \mathrm{~Pa}$ & $-206.8(66.35)$ & (Henderson and Woytek 2010) \\
\hline Critical temperature, ${ }^{\circ} \mathrm{C}(\mathrm{K})$ & $-39.25(233.90)$ & (Henderson and Woytek 2010) \\
\hline Critical pressure, $\mathrm{kPa}(\mathrm{atm})$ & $4530(44.7)$ & (Henderson and Woytek 2010) \\
\hline Critical volume, $\mathrm{cm}^{3} \mathrm{~mol}^{-1}\left(\mathrm{~m}^{3} \mathrm{~mol}^{-1}\right)$ & $123.8\left(1.238 \times 10^{-4}\right)$ & (Henderson and Woytek 2010) \\
\hline Heat of formation $\left(\Delta \mathrm{H}_{\mathrm{f}}\right), 25^{\circ} \mathrm{C}(298.15 \mathrm{~K}), 101.3 \mathrm{kPa}, \mathrm{kJ} \mathrm{mol}^{-1}$ & -124.7 & (Wagman et al. 1982) \\
\hline $\begin{array}{l}\text { Gibbs Free Energy of formation }\left(\Delta \mathrm{G}_{\mathrm{f}}\right), 25^{\circ} \mathrm{C}(298.15 \mathrm{~K}), 101.3 \\
\mathrm{kPa}, \mathrm{kJ} \mathrm{mol}^{-1}\end{array}$ & -83.2 & (Wagman et al. 1982) \\
\hline Entropy (S), $25^{\circ} \mathrm{C}(298.15 \mathrm{~K}), 101.3 \mathrm{kPa}, \mathrm{J} \mathrm{mol}^{-1}$ & 260.73 & (Wagman et al. 1982) \\
\hline Heat capacity $\left(\mathrm{C}_{\mathrm{p}}\right), 25^{\circ} \mathrm{C}(298.15 \mathrm{~K}), \mathrm{J} \mathrm{mol}^{-1} \mathrm{~K}^{-1}$ & 53.1 & (Wagman et al. 1982) \\
\hline $\begin{array}{l}\text { Water solubility, } 101.3 \mathrm{kPa}, 25^{\circ} \mathrm{C}(298.15 \mathrm{~K}), \mathrm{mol} \mathrm{NF}_{3} \mathrm{~mol}^{-1} \\
\mathrm{H}_{2} \mathrm{O}\end{array}$ & $1.4 \times 10^{-5}$ & (Henderson and Woytek 2010) \\
\hline Dipole moment, D & 0.234 & (Air Products 2010a) \\
\hline $\mathrm{N}-\mathrm{F}$ bond distance, $\mathrm{nm}$ & 0.137 & (Henderson and Woytek 2010) \\
\hline F-N-F bond angle, ${ }^{\circ}$ & 102.1 & (Henderson and Woytek 2010) \\
\hline Strength of $\mathrm{NF}_{2}-\mathrm{F}$ bond, $\mathrm{kJ}$ & 14 & (Kennedy and Colburn 1961) \\
\hline Strength of NF-F bond, kJ & 17 & (Kennedy and Colburn 1961) \\
\hline Strength of N-F bond, kJ & 17 & (Kennedy and Colburn 1961) \\
\hline
\end{tabular}

\subsection{Hydrogen Fluoride Properties}

Anhydrous HF is a corrosive and very hazardous colorless liquid or gas that has a boiling point of $19.5^{\circ} \mathrm{C}$ and the chemical and physical properties listed in Table 3.4.

Field and Shaffer (1967) found that HF's solubility in $\mathrm{LiF}_{-} \mathrm{BeF}_{2}\left(66 \% \mathrm{LiF} / 33 \% \mathrm{BeF}_{2}\right)$ in the temperature range $500-700^{\circ} \mathrm{C}$ obeyed Henry's law $\mathrm{c}_{\mathrm{HF}}=\mathrm{k}_{\mathrm{H}} \times \mathrm{P}_{\mathrm{HF}}$, where $\mathrm{c}_{\mathrm{HF}}$ is the concentration of $\mathrm{HF}$ in 
the melt, $\mathrm{k}_{\mathrm{H}}$ is the Henry's law constant, and $\mathrm{P}_{\mathrm{HF}}$ is the pressure of HF above the HF-saturated melt. The Henry's law constants $\mathrm{k}_{\mathrm{H}}$ for $\mathrm{HF}$ at 500,600 , and $700^{\circ} \mathrm{C}$ were, respectively, $3.37 \pm 0.13 \times 10^{-4}, 2.16 \pm$ $0.05 \times 10^{-4}$, and $1.51 \pm 0.06 \times 10^{-4} \mathrm{~mole} \mathrm{HF} /$ mole melt-atm. Thus treatment with HF will result in some free $\mathrm{F}^{-}$in treated $\mathrm{LiBeF}_{3}$ salt and possibly other salts.

Table 3.4. Selected Properties of Hydrogen Fluoride

\begin{tabular}{|c|c|c|}
\hline Property & Value & Reference \\
\hline Molecular mass, $\mathrm{g} \mathrm{mol}^{-1}$ & 20.006 & (Lide 2010) \\
\hline Melting point, ${ }^{\circ} \mathrm{C}(\mathrm{K})$ & $-83.36(189.79)$ & (Lide 2010) \\
\hline Boiling point at $101.3 \mathrm{kPa}(1 \mathrm{~atm}),{ }^{\circ} \mathrm{C}(\mathrm{K})$ & $19.54(292.69)$ & (Smith 2010) \\
\hline Liquid density at $25^{\circ} \mathrm{C}(298.15 \mathrm{~K}), \mathrm{kg} \mathrm{m}^{-3}$ & 0.958 & (Smith 2010) \\
\hline Gas density, ideal gas at $101.3 \mathrm{kPa}(1 \mathrm{~atm}) 25^{\circ} \mathrm{C}(298 \mathrm{~K}), \mathrm{kg} \mathrm{m}^{-3}$ & 0.818 & (Lide 2010) \\
\hline Specific gravity $\left(\mathrm{atm}, 21.1^{\circ} \mathrm{C}[294.2 \mathrm{~K}]\right.$, & $0.7($ air $=1)$ & (Air Products2009) \\
\hline Heat of vaporization at $101.3 \mathrm{kPa}, \mathrm{kJ} \mathrm{mol}^{-1}$ & 7.493 & (Smith 2010) \\
\hline Critical temperature, ${ }^{\circ} \mathrm{C}(\mathrm{K})$ & $188(461)$ & (Poling et al. 2001) \\
\hline Critical pressure, $\mathrm{kPa}(\mathrm{atm})$ & $6500(64.2)$ & (Poling et al. 2001) \\
\hline Critical volume, $\mathrm{cm}^{3} \mathrm{~mol}^{-1}\left(\mathrm{~m}^{3} \mathrm{~mol}^{-1}\right)$ & $69\left(0.69 \times 10^{-4}\right)$ & (Poling et al. 2001) \\
\hline $\begin{array}{l}\text { Heat of formation }\left(\Delta \mathrm{H}_{\mathrm{f}}\right) \text {, ideal gas at } 101.3 \mathrm{kPa}(1 \mathrm{~atm}) 25^{\circ} \mathrm{C} \\
(298.15 \mathrm{~K}), \mathrm{kJ} \mathrm{mol}^{-1}\end{array}$ & -272.5 & (Smith 2010) \\
\hline $\begin{array}{l}\text { Gibbs Free Energy of formation }\left(\Delta \mathrm{G}_{\mathrm{f}}\right) \text {, ideal gas at } 101.3 \mathrm{kPa}(1 \\
\text { atm) } 25^{\circ} \mathrm{C}(298.15 \mathrm{~K}), \mathrm{kJ} \mathrm{mol}^{-1}\end{array}$ & -274.6 & (Smith 2010) \\
\hline $\begin{array}{l}\text { Entropy (S), ideal gas, ideal gas at } 101.3 \mathrm{kPa}(1 \mathrm{~atm}) 25^{\circ} \mathrm{C} \\
(298.15 \mathrm{~K}), \mathrm{J} \mathrm{mol}^{-1} \mathrm{~K}^{-1}\end{array}$ & 173.7 & (Smith 2010) \\
\hline Vapor pressure at $25^{\circ} \mathrm{C}(298 \mathrm{~K}), \mathrm{kPa}$ & 122.9 & (Smith 2010) \\
\hline Liquid viscosity at $0^{\circ} \mathrm{C}(273.15 \mathrm{~K}), \mathrm{mPa} \cdot \mathrm{s}(\mathrm{cP})$ & 0.256 & (Smith 2010) \\
\hline $\begin{array}{l}\text { Thermal conductivity at } 25^{\circ} \mathrm{C}(298.15 \mathrm{~K}) \mathrm{J}\left(\mathrm{s} \bullet \mathrm{cm} \bullet^{\circ} \mathrm{C}\right) \\
\text { Liquid } \\
\text { vapor }\end{array}$ & $\begin{array}{l}4.1 \times 10^{-3} \\
2.1 \times 10^{-4}\end{array}$ & (Smith 2010) \\
\hline Heat capacity $\left(\mathrm{C}_{\mathrm{p}}\right)$ at $16^{\circ} \mathrm{C}(289.15 \mathrm{~K}), \mathrm{J} \mathrm{mol}^{-1} \mathrm{~K}^{-1}$ & 50.6 & (Smith 2010) \\
\hline Water solubility, $101.3 \mathrm{kPa}, 25^{\circ} \mathrm{C}(298.15 \mathrm{~K}), \mathrm{mol} \mathrm{NF}_{3} \mathrm{~mol}^{-1} \mathrm{H}_{2} \mathrm{O}$ & Very soluble & (Lide 2010) \\
\hline Dipole moment, D & 1.830 & (Air Products 2010a) \\
\hline
\end{tabular}

\subsection{HF and $\mathrm{NF}_{3}$ Use Considerations}

Both $\mathrm{HF}$ and $\mathrm{NF}_{3}$ have characteristics that must be managed for safe use and release. HF is a highly toxic and corrosive gas that can have significant health consequences if an individual is exposed. HF is also a highly reactive gas that can react with certain metals to release toxic fumes or explosive hydrogen. $\mathrm{NF}_{3}$ is only slightly toxic, and is only reactive at high temperatures and when exposed to certain physical conditions, but it has significant global warming potential.

To illustrate the differences between the hazards of the two gases, Table 3.5 provides Air Products National Fire Protection Association's (NFPA's) and Hazardous Material Identification System (HMIS) hazard ratings for $\mathrm{NF}_{3}$ and for $\mathrm{HF}$ and $\mathrm{F}_{2}$, the commonly used fluorinating and/or oxidizing agents. Both NFPA and HMIS use a rating scale of $0-4$ where $0=$ no hazard, $1=$ Slight Hazard, $2=$ Moderate Hazard, 
$3=$ Serious Hazard, and $4=$ Severe Hazard. As Table 3.5 shows, $\mathrm{NF}_{3}$ is a toxic gas but has no fire or reactivity hazards. HF is very toxic and corrosive (BOC Gases 2007b) and $\mathrm{F}_{2}$ is very toxic, corrosive, and an oxidizer (BOC Gases 2007a).

Table 3.5. Hazard ratings for $\mathrm{NF}_{3}$ (Air Products 2008), HF (Air Products 2009), and $\mathrm{F}_{2}$ (Air Products 2000)

\begin{tabular}{|c|c|c|c|c|c|c|}
\hline \multirow[b]{3}{*}{ Risk } & \multicolumn{6}{|c|}{ Hazard Rating $(0-4)$} \\
\hline & NFPA & HMIS & NFPA & HMIS & NFPA & HMIS \\
\hline & \multicolumn{2}{|c|}{$\mathrm{NF}_{3}$} & \multicolumn{2}{|c|}{$\mathrm{HF}$} & \multicolumn{2}{|c|}{$\mathrm{F}_{2}$} \\
\hline Health & 1 & 3 & 4 & 3 & 4 & 4 \\
\hline Flammability & 0 & 0 & 0 & 0 & 0 & 0 \\
\hline Reactivity & 0 & 0 & 1 & 2 & 4 & 4 \\
\hline Special & Oxidizer & NA & & NA & $\begin{array}{c}\text { Water } \\
\text { Reactive }\end{array}$ & NA \\
\hline
\end{tabular}

The characteristics of $\mathrm{HF}$ and $\mathrm{NF}_{3}$ require that their chemical hazards, compatibility with materials of construction, and their release be managed. Although the existing purification technology uses a combination of $\mathrm{HF}$ and $\mathrm{H}_{2}$, we recognize that $\mathrm{H}_{2}$ 's hazard arises from its well-established flammable and potentially explosive character.

\subsubsection{HF Health and Safety Considerations}

Anhydrous HF is a highly toxic (NFPA rating 4) and corrosive gas above $19.7^{\circ} \mathrm{C}$ that can have significant health effects. HF is not a carcinogen but can cause severe skin burns that may not be immediately noticeable. HF can penetrate the skin and damage underlying tissue. Severe inhalation exposure to HF can cause nose and throat burns, lung inflammation, pulmonary edema, and, if not promptly treated, other systemic effects such as depletion of calcium body levels. Unlike other acid burns, specialized medical care is required. The fluoride ion is extremely mobile and can penetrate quickly and deeply into the skin (Smith 2010).

In addition to the health risks from exposure to HF, HF is highly reactive and can react to produce heat and toxic fumes. Reactions with certain metals can generate potentially explosive hydrogen gas.

\subsection{2 $\quad \mathrm{NF}_{3}$ Health and Safety Considerations}

According to BOC Gas and Air Product Material Safety Data Sheets (BOC Gases 2008; Air Products 2008), $\mathrm{NF}_{3}$ is a non-corrosive, non-flammable, oxidizing, chemical asphyxiant that complexes with hemoglobin to form methemoglobin, thus reducing the capacity of blood to carry oxygen, causing cyanosis. Once exposure to $\mathrm{NF}_{3}$ stops, the methemoglobin reverts back to hemoglobin (Henderson and Woytek 2010). $\mathrm{NF}_{3}$ may also cause eye irritation. 


\subsubsection{1 $\mathrm{NF}_{3}$ Purification}

Air Products (Air Products 2010b) indicates that dry media such as activated charcoal or molecular sieves should not be used to purify $\mathrm{NF}_{3}$ because of the potential of rapid exotherms from sudden exposure of large amounts of $\mathrm{NF}_{3}$.

\subsubsection{2 $\mathrm{NF}_{3}$ and HF Toxicology}

Worker exposure to both $\mathrm{HF}$ and $\mathrm{NF}_{3}$ is governed by the Occupational Safety and Health Administration's (OSHA's) Title 29 Code of Federal Regulations 1910.1000, which limits the timeweighted average for an 8-h day to 3 and $10 \mathrm{ppm}$, respectively. Table 3.6 provides OSHA's permissible exposure limits (PELs), the American Conference of Governmental Industrial Hygienists' (ACGIH's) threshold limit values (TLVs), and the National Institute for Occupational Safety and Health's (NIOSH's) recommended exposure limits (RELs) for $\mathrm{HF}$ and $\mathrm{NF}_{3}$.

Table 3.6. Time-Weighted Average $\mathrm{NF}_{3}$ and HF Occupational Exposure Limits/Levels (OSHA 1993; 2006)

\begin{tabular}{|c|c|c|c|}
\hline Compound & OSHA PEL, ppm & ACGIH TLV, ppm & NIOSH REL, ppm \\
\hline $\mathrm{HF}$ (as $\mathrm{F}^{-}$) & 3 & 3 & 3 \\
\hline $\mathrm{NF}_{3}$ & 10 & 10 & 10 \\
\hline
\end{tabular}

\subsubsection{NF $\quad \mathrm{NF}_{3}$ Reactivity Hazards}

Barbier et al.(2010) provide a code of practice for safe use of $\mathrm{NF}_{3} . \mathrm{NF}_{3}$ is managed as a mildly toxic oxidizer with a relative oxidation potential of 1.6 where $\mathrm{O}_{2}$ has an oxidation potential of 1.0.

Barbier et al. (2010) state that the primary hazard from $\mathrm{NF}_{3}$ use arises if sufficient energy is provided to release fluorine and produce a self-propagating reaction with materials that are not compatible with fluorine. They also state that the $\mathrm{NF}_{3}$ hazard can be safely managed through proper design of equipment and appropriate management of factors such as temperature, pressure, adiabatic compression, and velocity in pipelines.

Although $\mathrm{NF}_{3}$ is relatively inert at atmospheric pressure and ambient temperature, the auto-ignition temperature of some combustible materials may decrease with increasing $\mathrm{NF}_{3}$ pressure as illustrated in Table 3.7 (Barbier et al. 2010) for copper (Cu), iron (Fe), and nickel (Ni). To manage the $\mathrm{NF}_{3}$ reactivity hazard, they recommend taking precautions to prevent conditions or inadvertent heating of $\mathrm{NF}_{3}$. These precautions include operating at as low as practical temperature, managing the $\mathrm{NF}_{3}$ pressure and velocity, using clean and compatible materials of construction, preventing mechanical shocks, preventing adiabatic compression, controlling flow friction, and preventing localized hot spots in equipment.

Table 3.7. Ignition Temperatures of Copper, Iron, and Nickel at 1 and 7 Bar $\mathrm{NF}_{3}$ (Barbier et al. 2010)

\begin{tabular}{cccc}
\hline & \multicolumn{3}{c}{ Ignition Temperature, ${ }^{\circ} \mathrm{C}$} \\
\cline { 2 - 4 } $\mathrm{NF}_{3}$ Pressure, bar & $\mathrm{Cu}$ & $\mathrm{Fe}$ & $\mathrm{Ni}$ \\
\hline 1 & 550 & 817 & 1187 \\
7 & 475 & 612 & 967 \\
\hline
\end{tabular}


Chen (2002) reports a $5.0 \% \mathrm{H}_{2}$ lower flammability limit in the $\mathrm{NF}_{3} / \mathrm{N}_{2}$ mixtures used in the semiconductor industry; the actual composition of the $\mathrm{NF}_{3} / \mathrm{N}_{2}$ was not provided. Based on this reported reactivity of $\mathrm{NF}_{3}$ with $\mathrm{H}_{2}$, this gas mixture should not be used to purify coolant salt.

\subsubsection{Materials of Construction for HF Use}

The materials of construction that can be used with anhydrous HF depend on a number of factors, including temperature, HF concentration, and method of use (Smith 2010). Mild steel can be used for most applications at temperatures $<66^{\circ} \mathrm{C}$ because steel contacted by $\mathrm{HF}$ forms a protective passivating layer of iron fluoride. Any chemical or physical action that disrupts this protective layer can lead to significantly greater corrosion rates. At higher temperatures, Monel ${ }^{\circledR}$ (a nickel-copper alloy) and Hastelloy- $C^{\circledR}$ (a nickel-molybdenum-chromium alloy) can be used. High gas-flow velocities can accelerate corrosion of metals.

\subsubsection{Materials of Construction for $\mathrm{NF}_{3}$ Use}

Important to managing the reactivity risks of $\mathrm{NF}_{3}$ is use of chemically compatible materials of construction at process temperatures. $\mathrm{NF}_{3}$ is non-corrosive to common metals below $70^{\circ} \mathrm{C}(343 \mathrm{~K})$ and can be used with steel, stainless steel, and nickel. Corrosion increases significantly if moisture or HF is present. $\mathrm{NF}_{3}$ is compatible with the fluorinated polymers such as Teflon ${ }^{\circledR}, \mathrm{Kel}^{-\mathrm{F}^{\circledR}}$, and Viton ${ }^{\circledR}$ at ambient conditions (Henderson and Woytek 2010).

Air Products (2010b) reports that during static exposure to $\mathrm{NF}_{3}$ containing $\leq 0.1 \%$ active fluorides as $\mathrm{HF}$, aluminum, stainless steel, Inconel ${ }^{\circledR}$, Monel ${ }^{\circledR}$, nickel, titanium, steel, copper, beryllium copper, aluminum bronze, steel, and tungsten. None of these metals had corrosion penetration rates greater than $0.43 \mathrm{mils} \mathrm{a}^{-1}\left(0.011 \mathrm{~mm} \mathrm{a}^{-1}\right)$. The 270 -day tests were performed at temperatures ranging from -78 to $71^{\circ} \mathrm{C}$ $(195$ to $344 \mathrm{~K})$ at pressures ranging from $2 \times 10^{-7}$ to $2.5 \times 10^{-6} \mathrm{psi}(0.001$ to $0.017 \mathrm{~Pa})$. Air Products reports that carbon steel, stainless steel, nickel and its alloys, and copper are suitable for use at low pressures $\left(<70 \mathrm{psig}\left[4.8 \times 10^{5} \mathrm{~Pa}\right]\right)$ and temperatures up to $150^{\circ} \mathrm{C}(423 \mathrm{~K})$. For pressures up to $1,450 \mathrm{psi}$ $\left(1.00 \times 10^{7} \mathrm{~Pa}\right)$ and ambient temperatures, carbon steel and stainless steel are suitable. For high-pressure and higher-temperature service, nickel and certain alloys of nickel and copper are preferred. Most metals will react with $\mathrm{NF}_{3}$ at temperatures in excess of $300^{\circ} \mathrm{C}(573 \mathrm{~K})$. The presence of fingerprints, halocarbon oils, and machine oils has been shown to significantly reduce the temperature resistance of metals including stainless steel and nickel.

As with the metallic materials of construction, Air Products reports it is important to thoroughly clean all non-metal components of oils, grease, and dirt using detergent or other suitable cleaning agent. Highly fluorinated polymers such as Teflon ${ }^{\circledR}$, Viton ${ }^{\circledR}, \mathrm{Kel}^{\mathrm{B}} \mathrm{F}^{\circledR}$, or Neoflon ${ }^{\circledR}$ are recommended with polytertafluoroethylene (PTFE)-Teflon ${ }^{\circledR}$ being the most compatible with $\mathrm{NF}_{3}$ to $150^{\circ} \mathrm{C}(423 \mathrm{~K})$ (Air Products 2010b). Barbier et al. (2010) recommend fluorocarbon polymers such as PTFE and polychlorotrifluoroethylene (PCTFE) that have lower heats of combustion than other hydrocarbon polymers.

Air Products (2010b) recommend the use of perfluorinated lubricants such as Krytox ${ }^{\circledR}$ or Fomblin ${ }^{\circledR}$ for vacuum pumps in $\mathrm{NF}_{3}$ service; hydrocarbon lubricants can react violently with $\mathrm{NF}_{3}$ and should not be used. Some halocarbon greases are dissolved by $\mathrm{NF}_{3}$. 
Barbier et al. (2010) report that the degree of self-propagation of reactions of materials with $\mathrm{NF}_{3}$ is dependent on $\mathrm{NF}_{3}$ pressure. They discuss promoted combustion tests of metal rods that showed that Monel $400^{\circledR}$, Nickel $200^{\circledR}$, and aluminum exhibited the least potential to self-propagate at pressures in excess of 70 bar $(7000 \mathrm{kPa})$. Hastelloy $\mathrm{C} 276^{\circledR}$ and $\mathrm{C} 22^{\circledR}$ demonstrated self-propagation at pressures between 5 and 50 bar (500 to $5000 \mathrm{kPa}$ ), while stainless and carbon steels demonstrated self-propagation at pressures $<5$ bar $(<500 \mathrm{kPa})$. They recommend that aluminum not be used even though it has a relatively high-resistance $\mathrm{NF}_{3}$ threshold pressure because of its high specific heat of combustion and its low melting point. Barbier et al. recommend that metal such as copper and its alloys, nickel, and Monel ${ }^{\circledR}$ be used for critical components, such as valve seat components and filters, in preference to stainless steels because of their better thermal conductivity.

\subsubsection{Effect of Temperature on $\mathrm{NF}_{3}$ Reactivity}

At temperatures up to $200^{\circ} \mathrm{C}\left(473 \mathrm{~K}\right.$ ), the oxidizing power of $\mathrm{NF}_{3}$ is comparable to oxygen. At higher temperatures, the decomposition to $\mathrm{NF}_{2}-$ and F-radicals becomes significant increasing with increasing temperature. The F-radical reacts readily with organic elements and metals producing more heat and causing additional decomposition of the $\mathrm{NF}_{3}$. At $400^{\circ} \mathrm{C} \mathrm{NF}_{3}$ 's reactivity becomes more like that of fluorine (Henderson and Woytek 2010). Combined shock wave and thermal studies indicate thermal decomposition peaks in the temperature range of 800 to $1200^{\circ} \mathrm{C}$ (MacFadden and Tschuikow-Roux 1973; Schott et al. 1973; Dorko et al. 1975; Evans and Tschuikow-Roux 1976).

Barbier et al. (2010) warns of operating at temperatures above $300^{\circ} \mathrm{C}$ because of $\mathrm{NF}_{3}$ decomposition into reactive species that will react with most materials. They warn particularly of reactions of polymers or certain metals that would react with the $\mathrm{NF}_{3}$ decomposition products producing additional heat and further disassociation. They recommend taking precautions to prevent conditions for inadvertent heating of $\mathrm{NF}_{3}$ and operating at an as low as practical temperature. Precautions to control temperature include control of $\mathrm{NF}_{3}$ flow velocity, use of materials of construction having low specific heats and good thermal conductivities, control of gas release rates to prevent adiabatic compression, and minimization of bends and crevices to eliminate flow friction.

The reaction with organics generally requires elevated temperatures and often proceeds explosively. Klapötke (2006) reports that at low temperatures $\mathrm{NF}_{3}$ reacts sluggishly, not reacting with $\mathrm{H}_{2}, \mathrm{CO}, \mathrm{CH}_{4}$, $\mathrm{H}_{2} \mathrm{~S}$, and many other compounds even though it is thermodynamically favorable. The reactions are prevented from proceeding by the kinetic stability of $\mathrm{NF}_{3}$ until sufficient activation energy is supplied by heating or an electric spark whereupon $\mathrm{NF}_{3}$ can react readily or explosively.

\subsubsection{Effects of NF3 Flow Velocity}

Barbier et al. (2010) state that $\mathrm{NF}_{3}$ velocity will create heat by particle impacts or flow friction on materials of construction. They recommend that maximum $\mathrm{NF}_{3}$ velocity be managed based on pipeline pressure above and below 15 bar $(1,500 \mathrm{kPa})$ :

- For pipeline pressures above 15 bar $(1,500 \mathrm{kPa})$, the maximum $\mathrm{NF}_{3}$ velocity should be controlled such that the product of the velocity and pressure in the pipeline does not exceed $450 \mathrm{bar} \mathrm{m} / \mathrm{s}$

- For pipeline pressures below 15 bar $(1,500 \mathrm{kPa})$, the velocity should be controlled to $<30 \mathrm{~m} / \mathrm{s}$. 


\section{Effects of Adiabatic Compression on $\mathrm{NF}_{3}$ Reactivity}

Care must be taken to prevent adiabatic compression of $\mathrm{NF}_{3}$ to further prevent sudden temperature increases, which could cause uncontrolled reactions with materials. A sudden increase in $\mathrm{NF}_{3}$ pressure will result in a rapid temperature increase (Barbier et al. 2010); for example, fully opening a valve and releasing high-pressure $\mathrm{NF}_{3}$ and rapidly pressurizing the remainder of the system. If the temperature increase is faster than the system can dissipate the resulting heat, the $\mathrm{NF}_{3}$ could heat to high temperatures and decompose into highly reactive species.

Reducing the rate at which the valve is opened can eliminate the risk of adiabatic compression. $\mathrm{NF}_{3}$ systems should be designed to eliminate the potential for adiabatic expansion. In systems using highpressure $\mathrm{NF}_{3}$, precautions must be taken to prevent any sudden heating that could occur during adiabatic compression arising from rapid introduction of high-pressure $\mathrm{NF}_{3}$ into a dead-end space (Henderson and Woytek 2010); this includes not using ball valves in $\mathrm{NF}_{3}$ service.

\section{Effects of Flow Friction on $\mathrm{NF}_{3}$ Reactivity}

Flow of $\mathrm{NF}_{3}$ across the surface of a material can create heat through energy distribution (Barbier et al. 2010). The more tortuous the passage that $\mathrm{NF}_{3}$ must take the greater the risk of what Barbier et al. call flow friction, which could cause heating and ignition of sensitive materials such as plastics. Good equipment and piping design is again important to mitigating risks from $\mathrm{NF}_{3}$ handling and use.

\subsubsection{HF Environmental Concerns}

Smith (2010) reports that the HF industry studies HF behavior in the event of a spill. When pressurized super-heated HF was released under certain conditions, it could form a heavier-than-air vapor cloud consisting of cold HF vapor and an aerosol of HF droplets. The HF did not form liquid pools. The results of this testing suggest that HF poses a localized hazard with little long-range effects.

\subsection{4 $\mathrm{NF}_{3}$ Environmental Concerns}

In 1995, Molina et al. (1995) recognized that $\mathrm{NF}_{3}$ was a significant greenhouse gas when they investigated the environmental lifetime of $\mathrm{NF}_{3}$ and considered its infrared band strengths to estimate its greenhouse warming potentials; Air Products supported this work. They estimated an environmental lifetime of $\sim 740$ years with a global warming potential (GWP) of 8,000 for a 100-year period. GWP is a relative scale using $\mathrm{CO}_{2}$ as its basis; i.e., $\mathrm{CO}_{2}$ has a GWP of 1 . Robson et al. (2006) revisited $\mathrm{NF}_{3}$ 's radiative efficiency and GWP and arrived at a GWP relative to $\mathrm{CO}_{2}$ of 17,200 for a 100-year period and concluded that $\mathrm{NF}_{3}$ is a "potent greenhouse gas." Prather and Hsu (2008) recalculated the lifetime of $\mathrm{NF}_{3}$ in the atmosphere to be 550 years thus reducing the 100-year GWP to 16,800. Even with this reduction $\mathrm{NF}_{3}$ remains a "potent greenhouse gas." Barbier et al. (2010) provide a GWP of 10,800 for $\mathrm{NF}_{3}$.

Tsai (2008) estimates that the total $\mathrm{NF}_{3}$ releases from the electronics industry of 3.6 to 56 metric tonnes per year based on their measurement of $\mathrm{NF}_{3}$ in the atmosphere. Weiss et al. (2008) estimate the annual release at 620 metric tonnes or $16 \%$ of the estimated 4000 metric tonnes produced annually. Prather and $\mathrm{Hsu}$ (2008) and Weiss et al. recommend that the release of $\mathrm{NF}_{3}$ be regulated as a "greenhouse" gas. 
The electronics industry began using $\mathrm{NF}_{3}$ as a replacement for other perfluorinated compounds such as carbon tetrafluoride $\left(\mathrm{CF}_{4}\right)$ and sulfur hexafluoride $\left(\mathrm{SF}_{6}\right)$, which have GWPs of 7,400 to 22,800 (de WildScholten et al. 2007) to reduce the electronic industry's releases of gases that would contribute to global warming. $\mathrm{NF}_{3}$ is attractive as a replacement cleaning agent for process chambers because it is essentially consumed (90-95\%) in use (Air Products 2010a; Robson et al. 2006).

Because of $\mathrm{NF}_{3}$ 's GWP, it may soon become a regulated gas with respect to environmental releases. de Wild-Scholten et al. (2007) indicate that the 2007 European Union regulations aim at reducing the emission of fluorinated greenhouse gases. Thus any consideration of $\mathrm{NF}_{3}$ use should consider options for $\mathrm{NF}_{3}$ recycle or abatement depending on the amounts that would be released once the process is engineered and defined.

\subsection{5 $\mathrm{NF}_{3}$ Effluent Management}

Because of the importance of $\mathrm{NF}_{3}$ as an etchant and chamber-cleaning agent in the semiconductor industry and its potential impact as a global warming gas, many have been focusing on developing technologies for controlling its release. The two general strategies that are used or are being investigated are destruction and recycle. This section discusses these two concepts.

\subsubsection{1 $\quad \mathrm{NF}_{3}$ Abatement}

Approaches and technologies have been developed to control $\mathrm{NF}_{3}$ effluents from electronics etching processes. The U.S. Climate Change Technology Program (2003) identifies thermal destruction and plasma destruction as the two methods available for abating perfluorocarbon emissions. The thermal destruction approach may be used for treating a small process' effluent gases, e.g., point of treatment, or it can be used to treat a whole facility's exhaust gases. The plasma destruction approach has a smaller capacity and can only be used for small effluent streams.

Direct and catalyzed thermal combustion systems are being used (U.S. Climate Change Technology Program 2003). Commercial devices for destroying the perfluorocompounds used in the semiconductor industry include the Edwards TPU 4214, which oxidizes with an advanced burner technology, and the Hitachi Catalytic Oxidation System, which can be used for $\mathrm{CF}_{4}, \mathrm{C}_{2} \mathrm{~F}_{6}, \mathrm{C}_{4} \mathrm{~F}_{8}$, and $\mathrm{SF}_{6}$. In general the HF produced is removed by aqueous scrubbers.

In plasma-based systems, plasmas are formed from the effluent stream using radio frequencies (low pressure systems) or microwaves (streams at atmospheric pressure) and oxidizing and/or reducing conditions (U.S. Climate Change Technology Program 2003). Commercial devices identified by the U.S. Climate Control Program include the Litmas, Inc. Blue device that uses inductively coupled plasma while their Red device uses microwaves. Plasma-abatement technologies function by decomposing the perfluorocompound and controlling the release of the fragments produced.

de Wild-Schloten et al.(2007) report that the main type of system used to abate the fluorinecontaining etchants used in the electronics industry is the burner-scrubber. In this process, the waste gas is first burned using natural gas, propane, or hydrogen with excess oxygen. The high temperature causes these fluorinated compounds to decompose and the decomposition products react with the burning gas compounds, hydrogen, and oxygen; hydrogen is required for effective treatment. The F-radical reacts with hydrogen to form HF. The hot exhaust is rapidly cooled to prevent recombination of the 
decomposition products and then scrubbed using water or a caustic sodium or potassium hydroxide solution. The fluoride-bearing wastewater is typically treated to precipitate the fluoride as calcium fluoride. Depending on the fluorine-containing gas, the typical abatement efficiency is 95 to $99 \%$. The composition of the exhaust must be monitored to confirm that little or no recombination occurs; de WildScholten et al. suggest development of an infrared spectroscopic method.

Henderson and Wyotek (2010) report that commercial scrubbing systems are available for controlling release of unwanted $\mathrm{NF}_{3}$ by high-temperature pyrolysis of $\mathrm{NF}_{3}$ over reactive substrates. Alternative processes have been suggested Chang et al. (2000) who describe an approach for destroying $\mathrm{NF}_{3}$ using a barium titanate $\mathrm{BaTiO}_{3}$ packed-bed plasma reactor and capturing the products from the plasma using a calcium carbonate $\mathrm{CaCO}_{3}$ sorbent bed. Radoiu and Hussain (2009) describe an atmospheric microwave plasma for destroying $\mathrm{SF}_{6}$, another perfluorocompound used in the semiconductor industry for thin-film etching and cleaning CVD chambers. Hong et al. (2006) describe the use of an atmospheric plasma torch to abate $\mathrm{NF}_{3}$ and $\mathrm{SF}_{6}$.

The abatement strategies provided by Barbier et al. (2010) are as follows:

1. $2 \mathrm{NF}_{3}+2 \mathrm{AlCl}_{3} \rightarrow \mathrm{N}_{2}+3 \mathrm{Cl}_{2}+2 \mathrm{AlF}_{3} @ 70^{\circ} \mathrm{C}$

2. $2 \mathrm{NF}_{3}+3 \mathrm{H}_{2} \rightarrow \mathrm{N}_{2}+6 \mathrm{HF}$ (very intensive reaction)

3. $\mathrm{NF}_{3}+\mathrm{Fe} \rightarrow \mathrm{FeF}_{2}, \mathrm{FeF}_{3}+\mathrm{N}_{2} @ 300-400^{\circ} \mathrm{C}$

4. $\mathrm{NF}_{3}+\mathrm{Si} \rightarrow \mathrm{SiF}_{4}+\mathrm{N}_{2} @>400^{\circ} \mathrm{C}$

5. thermal ionization and reaction with added partners

6. plasma ionization and reaction with added partners

7. in combination with PFC recovery systems

8. reclamation at cylinder filling facilities

Others are investigating enhancements to the thermal destruction or plasma approaches. Vileno and her coworkers $(1995 ; 1996)$ investigated the thermal decomposition of $\mathrm{NF}_{3}$ over selected metals and oxides with some success. Grothaus and Fanick (1996) investigated a non-thermal pulsed corona plasma reactor to destroy $\mathrm{NF}_{3}$. They obtained $>99.9 \%$ destruction of the $\mathrm{NF}_{3}$ and found that the addition of hydrogen into the reactor dramatically improved the reactors performance by converting the released fluorine as HF.

Abatement technologies are currently in use by the semiconductor industry to control $\mathrm{NF}_{3}$ releases and in concept they appear to be applicable to $\mathrm{NF}_{3}$ 's use as a purification agent. Whether these technologies are directly applicable to the scale required for purifying MSR coolant and heat-transfer salts would require further evaluation.

\subsubsection{2 $\quad \mathrm{NF}_{3}$ Recycle}

$\mathrm{NF}_{3}$ recycle is an attractive approach for controlling emissions and making sure that $\mathrm{NF}_{3}$ is efficiently used. Praxair, Inc. in collaboration with EcoSys (1997) has developed a wet-and-dry scrubber pretreatment system coupled with a cryogenic system to recover the perfluorcompounds used in the semiconductor industry including $\mathrm{NF}_{3}$. The system consists of two caustic-based wet scrubbers to 
remove the more water-reactive or soluble impurities such as $\mathrm{SiF}_{4}, \mathrm{HF}, \mathrm{WF}_{6}, \mathrm{SOF}_{2}, \mathrm{SO}_{2} \mathrm{~F}_{2}, \mathrm{COF}_{2}, \mathrm{CO}_{2}$, and $\mathrm{F}_{2}$. Their dry scrubber is a chemisorption method using proprietary resins to remove hydrides such as $\mathrm{SiH}_{4}, \mathrm{NH}_{3}$, and $\mathrm{PH}_{3}$.

The effluent from the pretreatment system is dried by a dessicant (Type 13X molecular sieve) before passing into a cryogenic system using liquid nitrogen. The cryogenic system recovers the perfluorocarbons for reuse. The system has been used by Texas Instruments and is used to treat gas streams containing carrier gases nitrogen, hydrogen, helium, oxygen, or argon (Praxair, Inc. 1997).

Praxair, Inc.'s experience indicates that it is possible to recover $\mathrm{NF}_{3}$ for recycle from gas streams containing many of the constituents $\left(\mathrm{O}_{2}, \mathrm{H}_{2} \mathrm{O}\right)$ that will be present in the effluent from an $\mathrm{NF}_{3}$-based fluoride-salt coolant purification process. The demands on the recycle system should not be as great as those for which the Praxair-EcoSys system was designed. The recycle system will have to be designed and engineered to accommodate the scale, unique characteristics, and properties of a system designed to remove impurities from a high-temperature system with its own gas stream composition.

\subsubsection{HF Effluent Management}

As described for various perfluorocompound effluent management approaches, a common theme is burning the perfluorocarbon to produce HF, which is subsequently removed from the effluent gas stream using an aqueous scrubber. The aqueous scrubber uses the high solubility of HF in water for removal. The system for HF control is significantly less complicated than might be required for $\mathrm{NF}_{3}$. 



\subsection{Reported $\mathrm{NF}_{3}$ and HF Use as Purification Agents for Fluorides}

Hydrogen fluoride and HF mixed with $\mathrm{H}_{2}$ are the primary reagents for removing contaminant water, hydroxide, and oxygen from the molten fluoride salts that have been considered as the molten salt reactor's primary coolant and heat-transfer media. Hydrogen fluoride and HF mixed with various other gases such as $\mathrm{He}$ or $\mathrm{Ar}$ or $\mathrm{H}_{2}$ have been used in other purification and processing applications for fluoride salts including fluoride glass preparations. This section discusses reported uses of $\mathrm{HF}$ and $\mathrm{NF}_{3}$ to purify fluoride-based systems.

\subsection{Traditional Fluoride Coolant Purification}

The baseline method for purification of fluoride salts was developed for the molten salt reactor experiment (MSRE) (Shaffer 1971). This method consists of sparging the molten salt with a mixture of $\mathrm{H}_{2}$ and HF until the desired level of oxide has been removed. This method is more effective at lower temperatures, so it is optimal thermodynamically to perform the process at the lowest temperature at which the salt mixture can be maintained in a molten condition. In this case, the process temperature chosen for the MSRE was $600^{\circ} \mathrm{C}$.

As provided by Holcomb et al. (2009), the main salt contaminants would be the oxides and hydroxides of the fluoride salt components, with the main contaminant of concern for flibe being $\mathrm{BeO}$ as discussed earlier. Originally, anhydrous HF was used to force the equilibrium presented in Equation (4.1) to reform $\mathrm{BeF}_{2}$, consequently removing the oxide contaminants. This simple use of HF for the purification process ended up having a significant disadvantage. This disadvantage is that the HF attacks the construction materials of the vessel in which the salt is held according to the equation

$$
M^{0}+x H F \underset{\leftarrow}{\rightarrow} M F_{x}+\frac{x}{2} H_{2}
$$

After being fluorinated, the metals of the containment are dissolved into the salt, allowing deeper and deeper layers of the material to be fluorinated with subsequent corrosion of the container. In addition, as the HF is sparged into the molten salt, only a fraction of it reacts or is entrained, while a fraction bubbles up through the salt into the gas phase. This gas leaving through the top of the molten salt is largely HF with a small fraction of $\mathrm{H}_{2} \mathrm{O}$. This effluent gas fluorinates the surface of the containment in contact with the gas. Originally, excess HF was sparged through the molten salt so that there would be excess HF entrained, so that if any oxide contamination were to occur during operation, the excess HF could keep Equation (4.1) favoring the metal fluoride.

To dampen the corrosion of the containment materials and lower the concentration of HF in the effluent gas, $\mathrm{H}_{2}$ was added to the HF feed stream, effectively driving Equation 4.1 to the left. The presence of the $\mathrm{H}_{2}$ in the effluent stream of gas leaving the salt during sparging also decreased the concentration of the HF, making it easier to scrub or absorb the effluent HF. For the MSRE, the effluent HF was absorbed on sodium fluoride pellets. This process was not effective for HF concentrations above $10 \%$, which limited the level of HF that could be present in the feed stream. In addition to sparging with a low concentration of $\mathrm{HF}$ in $\mathrm{H}_{2}$, secondary sparging steps using $100 \% \mathrm{H}_{2}$ were performed to reduce metal contaminants in the salt. 
The use of $\mathrm{H}_{2} / \mathrm{HF}$ mixtures continues to be a baseline method for the purification of fluoride salts. Reports as recent at 2009 continue to reference the direct use of $\mathrm{H}_{2} / \mathrm{HF}$ mixtures (Calderoni et al. 2009) or use modified versions of this method involving $\mathrm{Ar} / \mathrm{H}_{2} / \mathrm{HF}$ mixtures (Olson et al. 2009). To control the corrosivity of the fluoride coolant salts when used in a fusion reactor, Caleroni et al. added contact with Be metal to control the free fluoride potential arising from neutron capture reactions. Overall, the optimization of $\mathrm{H}_{2} / \mathrm{HF}$ mixture use has become a balancing act of providing enough $\mathrm{HF}$ to properly fluorinate the oxide and hydroxide contaminants in the salt while limiting the presence of excess HF to prevent the corrosion of the materials of construction.

In their investigation of water-free beryllium fluoride $\left(\mathrm{BeF}_{2}\right)$, Baldwin and Mackenzie (1979) purified the $\mathrm{BeF}_{2}$ by double-distillation and treatment with $850^{\circ} \mathrm{C}(1123 \mathrm{~K}) \mathrm{HF} / \mathrm{H}_{2}$. They distilled the $\mathrm{BeF}_{2}$ at $850^{\circ} \mathrm{C}(1123 \mathrm{~K})$ under a $4-\mathrm{kPa}\left(30\right.$-torr) vacuum and condensed it at $450^{\circ} \mathrm{C}(723 \mathrm{~K})$ in a nickel distiller. After the second distillation purification, they purged the inside of the $850^{\circ} \mathrm{C}(1123 \mathrm{~K})$ distiller with an unspecified $\mathrm{HF} / \mathrm{H}_{2}$ mixture.

Petti et al. (2006)purified the flibe (Li:Be molar ratio 2:1) used for the second Japan/U.S. Program on Irradiation Tests for Fusion Research (Jupiter-II) by purging the molten flibe with gas mixtures of $\mathrm{He}, \mathrm{H}_{2}$, and $\mathrm{HF}$ at $520^{\circ} \mathrm{C}$. Their flibe was prepared from dried research-grade (99.9\% pure) $\mathrm{LiF}$ and $\mathrm{BeF}_{2}$. After treatment with the purification gases, Petti et al. filtered the molten salt through a $60-\mu \mathrm{m}$ metal mesh frit. The $\mathrm{O}, \mathrm{C}, \mathrm{N}, \mathrm{Fe}, \mathrm{Ni}$, and $\mathrm{Cr}$ impurities of their ingredients and flibe used in the Jupiter-II tests are provided in Table 4.1 .

Table 4.1. Impurities in Flibe Ingredients and Final Salt Used in JUPITER-II Testing (Petti et al. 2006)

\begin{tabular}{lcccccc}
\hline & $\mathrm{O}, \mathrm{ppm}$ & $\mathrm{C}, \mathrm{ppm}$ & $\mathrm{N}, \mathrm{ppm}$ & $\mathrm{Fe}, \mathrm{ppm}$ & $\mathrm{Ni}, \mathrm{ppm}$ & $\mathrm{Cr}, \mathrm{ppm}$ \\
\hline $\mathrm{BeF}_{2}$ & 5700 & $<20$ & 58 & 295 & 20 & 18 \\
$\mathrm{LiF}$ & 60 & $<20$ & 78 & 100 & 30 & 4 \\
flibe & 560 & 10 & 32 & 260 & 15 & 16 \\
\hline
\end{tabular}

\subsection{Fluoride Glass Purification}

In support of the fiber-optic industry, there was an intense effort to identify effective technologies for removing the oxide, hydroxide, and water impurities from the candidate fluoride-based glasses. Fluoridebased glasses such as fluorozirconate glasses based on zirconium tetrafluoride $\left(\mathrm{ZrF}_{4}\right)$ offer lower optical attenuation and have an extended infrared (IR) transparency compared to silica. As part of this development effort, researchers investigated $\mathrm{NF}_{3}$ as a purifying agent that would work by fluorinating any oxides or hydroxides to the fluoride. The fluoride-based glasses are very hygroscopic compared to silicabased glasses, and their performance is significantly affected by oxide and hydroxide impurities (Atkins and Broer 1988) thus making removal of impurities very important. These studies are quite promising with respect to the use of $\mathrm{NF}_{3}$ to purify heat-transfer salts.

In general, the approach used to eliminate oxide, hydroxide, and water from the fluoride-glasses is to perform the melting operation under a reactive atmosphere or to perform Reactive Atmosphere Processing (RAP). A variety of gases have been investigated for RAP including $\mathrm{CCl}_{4}, \mathrm{HF}, \mathrm{CF}_{4}, \mathrm{SF}_{6}, \mathrm{CS}_{2}$, (Poulain 1983; Maze et al. 1984) and $\mathrm{NF}_{3}$ (Iqbal et al. 1992; Nakai et al. 1985; Nakai et al. 1986). $\mathrm{NF}_{3}$ is unique with its combined ability to both oxidize and fluorinate. 


\subsection{1 $\quad \mathrm{NF}_{3}$ Purification of Fluoride Glasses}

Iqbal et al. (1992) used $300^{\circ} \mathrm{C} \mathrm{NF}_{3}$ to remove residual water from their preparation of $\mathrm{AlF}_{3}$-based glass before drawing the glass fibers. They prepared two sets of transparent, bubble- and crystal-free glass rods with the nominal mol\% composition $30.2 \mathrm{AlF}_{3}-20.2 \mathrm{CaF}_{2}-13.2 \mathrm{SrF}_{2} 14.1 \mathrm{BaF}_{2}-10.2 \mathrm{ZrF}_{4}-$ 8.3 $\mathrm{YF}_{3}-3.8 \mathrm{NaF}-2.5 \mathrm{PbF}_{2}$.

Nakai et al. (1985) investigated the effects of $\mathrm{NF}_{3} \mathrm{RAP}$ on the stability of a fluoride-based glass $53 \mathrm{ZrF}_{4}-20 \mathrm{BaF}_{2}-20 \mathrm{NaF}-4 \mathrm{LaF}_{3}-3 \mathrm{AlF}_{3}$ doped with a variety of sodium salts $\mathrm{Na}_{2} \mathrm{CO}_{3}, \mathrm{Na}_{2} \mathrm{SO}_{4}, \mathrm{NaNO}_{3}$, and $\mathrm{Na}_{2} \mathrm{HPO}_{4}$ to $1 \mathrm{~mol} \%$. Based on their IR analyses of the glasses, Nakai et al. postulate that processing the $\mathrm{Na}_{2} \mathrm{CO}_{3}$ - and $\mathrm{NaNO}_{3}$-glasses in $600^{\circ} \mathrm{C} \mathrm{NF}_{3}$ produced a suitable glass by converting the salt or its oxide arising from thermal decomposition to its fluoride; they found that simple thermal decomposition in Ar produced a glass containing oxide that scattered light. Treatment of the $\mathrm{Na}_{2} \mathrm{SO}_{4}$ - and $\mathrm{Na}_{2} \mathrm{HPO}_{4}$-doped glasses by $600^{\circ} \mathrm{C} \mathrm{NF}_{3}$ had no effect on the dopant salts.

In later studies, Nakai et al. (1986) investigated $\mathrm{Ar}$ and $\mathrm{NF}_{3}$ for RAP of the same composition glasses previously tested- $53 \% \mathrm{ZrF}_{4}-20 \% \mathrm{BaF}_{2}-20 \% \mathrm{NaF}_{-} \% \mathrm{LaF}_{3}-3 \% \mathrm{AlF}_{3}$ - to which they had added $\mathrm{NaOH}$ or $\mathrm{ZrO}_{2}$; composition is in mol\%. They found that by processing glass doped with $0.1 \mathrm{~mol} \% \mathrm{NaOH}$ in $600^{\circ} \mathrm{C} \mathrm{NF}_{3}$ for $30 \mathrm{~min}$ produced a glass free of $\mathrm{OH}^{-}$. Processing a $1.0 \mathrm{~mol} \% \mathrm{NaOH}$-doped glass for $1 \mathrm{~h}$ at $600^{\circ} \mathrm{C}$ also produced a glass free of any bulk $\mathrm{OH}^{-}$contamination. Processing the $\mathrm{NaOH}$-doped glass under Ar did not eliminate $\mathrm{OH}^{-}$from the bulk glass. In contrast to Robinson et. al.'s (1980) difficulties in preventing the formation of $\mathrm{ZrO}_{2}$ in their $\mathrm{ZrF}_{4}$-containing glasses, Nakai et al. (1986) found that processing a $0.5-\mathrm{mol}_{0} \mathrm{Z \textrm {ZO } _ { 2 }}$-doped glass under $\mathrm{NF}_{3}$ produced no crystals in the glass, thereby indicating that the $\mathrm{ZrO}_{2}$ was converted to the fluoride. Processing 0.1-mol\% $\mathrm{ZrO}_{2}$-doped glass in Ar produced a glass that scattered light, but reprocessing this glass for $1 \mathrm{~h}$ produced eliminated the scattering. Nakai et al. concluded that processing under $\mathrm{NF}_{3}$ will eliminate hydroxides and oxides in glasses.

The studies of the use of $\mathrm{NF}_{3}$ to remove water from the molten fluoride salts used to make fluoride glasses indicate that $\mathrm{NF}_{3}$ should be an effective purification agent for the fluoride salt coolants to be used in the FHR-TS.

\subsubsection{HF Purification of Fluoride Glasses}

In Robinson et al.'s studies (1980) of 63- $\mathrm{mol}^{2} \mathrm{ZrF}_{4}, 15-\mathrm{mol}_{0} \mathrm{ThF}_{4}$, and 38- $\mathrm{mol}_{0} \mathrm{BaF}_{2}$ glass, they purified their prepared glass through a multi-step process. The $\mathrm{ZrF}_{4}$ was treated with dry $400^{\circ} \mathrm{C}(673 \mathrm{~K})$ $\mathrm{HF}$ and then sublimed at $900^{\circ} \mathrm{C}(1173 \mathrm{~K})$ in a stainless-steel sublimator. The $\mathrm{BaF}_{2}$ was treated with dry $1000^{\circ} \mathrm{C}(1273 \mathrm{~K}) \mathrm{HF}$. The $\mathrm{ThF}_{4}$ was prepared by dissolution in a $49 \% \mathrm{HF}$ solution followed by evaporation of the water and then treated with HF until melting occurred. To make the glass, the fluoride salts were combined, heated to $300^{\circ} \mathrm{C}$ in a vacuum, heated in $5 \mathrm{~h}$ to $900^{\circ} \mathrm{C}(1173 \mathrm{~K})$ in vitreous carbon or platinum crucibles and $10-\mathrm{mol} \% \mathrm{HF} / \mathrm{He}$, and then held at temperature for $5 \mathrm{~h}$ in $10 \% \mathrm{HF} / \mathrm{He}$ to complete the glass processing. This glass was a mixture of a transparent, colorless phase containing a small amount of an opaque-black phase that contained half the fluoride of the transparent phase. The amount of the opaque-black phase increased with increasing $\mathrm{HF} / \mathrm{He}$ processing times. Robinson et al. postulated that the opaque-black phase resulted from dissociation of $\mathrm{ZrF}_{4}$; they observed $\mathrm{F}_{2}$ when heating $\mathrm{ZrF}_{4}$ above $500^{\circ} \mathrm{C}$. They concluded that $\mathrm{HF}$ was not an effective RAP for these $\mathrm{ZrF}_{4}$-containing glasses because above $530^{\circ} \mathrm{C} \mathrm{ZrO}_{2}$ is thermodynamically favorable even in the presence of $\mathrm{HF}$. As a side note, they were very satisfied with $\mathrm{CCl}_{4}$ in $\mathrm{He}$ as their RAP. 



\subsection{Process Considerations}

The method that has historically been used for the removal of impurities from the coolant and heattransfer salts is sparging a mixture of $\mathrm{H}_{2}$ and $\mathrm{HF}$ through the salt (Shaffer 1971). To improve the reaction kinetics for this process, the salt should be molten so that the gas can be transferred readily through the salt and interact more easily with the contaminants.

In addition to the salt simply being in a molten state, the salt's viscosity is important because it affects the dispersability of the fluorinating agent through the salt. With $\mathrm{NF}_{3}$ 's low dipole compared to that of $\mathrm{HF}$, it is likely that $\mathrm{NF}_{3}$ will have a lower solubility than $\mathrm{HF}$, which could affect the fluorination process. If the viscosity is too low, the gas may quickly bubble through the salt and be released through the top of the molten salt without having the necessary residence time to effectively react. If the viscosity is too high, the salt could trap the fluorinating gas bubbles and limit the dispersability due to resistance to transport.

These phenomena will affect the conditions used to optimize the purification system and may determine the kinetic effectiveness of the fluorinating agents. The design of the actual purification process and the optimization of the purification conditions for maximum kinetic effectiveness will be necessary engineering issues in the future. Williams et al. (2006) and Williams (2006) provide a thorough resource for the candidate coolant salts. These fluoride salts have melting points from 390 to $460^{\circ} \mathrm{C}$ with viscosities ranging from 2.6 to $5.6 \mathrm{cP}$ at $700^{\circ} \mathrm{C}$. 



\subsection{Thermodynamics of $\mathrm{NF}_{3}$ and HF Purification of MSR Coolant and Secondary Heat-Transfer Salts}

To further evaluate $\mathrm{NF}_{3}$ as a potential replacement fluorinating purification agent for removing contaminants from the primary coolant, the secondary loop heat-transfer salts, and the DRACS salt, we used HSC Chemistry (Roine et al. 2009) to calculate the thermodynamics of the reaction of $\mathrm{NF}_{3}$ and $\mathrm{HF}$ with potential contaminants. We focused on the contaminants that could arise from the reactions of the fluoride salts with environmental water and oxygen. In addition, we considered the use of $\mathrm{NF}_{3}$ as a chemical agent to remove and/or fluorinate graphite (carbon), and tristructural-isotropic (TRISO) fuel components (pyrolytic carbon, silicon carbide, uranium dioxide).

The general approach used for these calculations was to input the various coolant salt components in the proper stoichiometries, the potential mixed-fluoride salts provided in the HSC Chemistry database that could arise, and the potential oxide and hydroxide contaminants, and then calculate the thermodynamic properties when $\mathrm{NF}_{3}$ or $\mathrm{HF} / \mathrm{H}_{2}$ are added. As with all thermodynamic calculations, these calculations assume optimal mixing and ignore reaction kinetics. On the other hand, thermodynamic values provide an excellent measure of the promise of whether a particular reaction can be made to occur.

For its calculations, HSC Chemistry (Roine et al. 2009) uses its compendium of thermodynamic properties of enthalpy of formation $\left(\Delta \mathrm{H}_{\mathrm{f}}\right)$, entropy of formation $\left(\Delta \mathrm{S}_{\mathrm{f}}\right)$, and free energy of formation $\left(\Delta \mathrm{G}_{\mathrm{f}}\right)$ in various compound states. The reaction enthalpy is calculated by subtracting the sum of the heats of formation of the reactants from the sum of the heats of formation of the products or $\Delta \mathrm{H}_{\mathrm{rx}}=\Delta \mathrm{H}_{\mathrm{f}(\text { products })}-$ $\Delta \mathrm{H}_{\mathrm{f}(\text { reactants) }}$. For example, for the reaction where 2 moles of $\mathrm{X}$ react with 1 mole of $\mathrm{Y}$ to produce 1 mole of $\mathrm{XY}$ the reaction enthalpy change $\left(\Delta \mathrm{H}_{\mathrm{rx}}\right)$ would be

$$
\Delta \mathrm{H}_{\mathrm{rX}}=\left(1 \times \Delta \mathrm{H}_{\mathrm{f}(\mathrm{XY})}\right)-\left(2 \times \Delta \mathrm{H}_{\mathrm{f}(\mathrm{X})}\right)-\left(1 \times \Delta \mathrm{H}_{\mathrm{f}(\mathrm{Y})}\right)
$$

to take into account the stoichiometry of the balanced reaction. The reaction's entropy and free-energy changes are calculated likewise. HSC Chemistry (Roine et al. 2009) considers state changes in its calculations.

A reaction is thermodynamically favorable if a reaction free energy $\left(\Delta \mathrm{G}_{\mathrm{rx}}\right)$, which is calculated using the relationship $\Delta \mathrm{G}_{\mathrm{rx}}=\Delta \mathrm{H}_{\mathrm{rx}}-\left(\mathrm{T} \times \Delta \mathrm{S}_{\mathrm{rx}}\right)$, is negative. Typically, a negative $\Delta \mathrm{H}_{\mathrm{rx}}$ indicates that a reaction is favorable because it is usually the dominating thermodynamic property. Occasionally entropy changes can dominate.

This section provides the calculated reaction enthalpy change $\left(\Delta \mathrm{H}_{\mathrm{rx}}\right)$, entropy change $\left(\Delta \mathrm{S}_{\mathrm{rx}}\right)$, and freeenergy change $\left(\Delta \mathrm{G}_{\mathrm{rx}}\right)$ for reactions of $\mathrm{NF}_{3}$ and $\mathrm{HF}$ with potential contaminants in the coolant and heattransfer fluoride salts flibe, flinak, $\mathrm{KF}_{-} \mathrm{ZrF}_{4}, \mathrm{KF}_{-} \mathrm{KBF}_{4}$, and $\mathrm{LiF}-\mathrm{NaF}-\mathrm{RbF}$, and for components of TRISO fuel. The results are normalized to per mole $\mathrm{F}$ to provide a direct comparison between the thermodynamic values for $\mathrm{NF}_{3}$ and $\mathrm{HF}$.

The apparent trend of discontinuities in values provided in the tables below arises from state changes. We include the less energetically favorable alternative $\mathrm{NF}_{3}$ reactions that produce oxides of nitrogen instead of $\mathrm{N}_{2}$. The tables provide calculated thermodynamic values for the temperature range 100 to $1000^{\circ} \mathrm{C}$ per mol of fluorine. Although $\mathrm{H}_{2}$ is used with $\mathrm{HF}$ in current purification treatments to make sure 
the released oxygen is converted to water, we found the process was thermodynamically neutral and was not included in each reaction.

\subsection{Flibe}

As discussed earlier, the predominant oxide contaminant in flibe should be $\mathrm{BeO}$. In addition, we provide the calculated thermodynamics for treatment of the oxides and hydroxides for beryllium and lithium.

As Table 6.1 and Table 6.2 show, $\mathrm{NF}_{3}$ 's potential reactions with $\mathrm{BeO}$ are exothermic and thus are favored independent of the product gases. Comparison of Table 6.1 and Table 6.2 shows that formation of $\mathrm{N}_{2}$ is the more thermodynamically favorable reaction.

Table 6.1. Calculated Thermodynamic Values for Fluorination of $\mathrm{BeO}$ by $\mathrm{NF}_{3}$ and $\mathrm{HF}$

\begin{tabular}{|c|c|c|c|c|c|c|}
\hline \multirow[b]{3}{*}{$\mathrm{T},{ }^{\circ} \mathrm{C}$} & \multicolumn{3}{|c|}{$3 \mathrm{BeO}+2 \mathrm{NF}_{3(\mathrm{~g})}=3 \mathrm{BeF}_{2}+\mathrm{N}_{2(\mathrm{~g})}+1.5 \mathrm{O}_{2(\mathrm{~g})}$} & \multicolumn{3}{|c|}{$\mathrm{BeO}+2 \mathrm{HF}_{(\mathrm{g})}=\mathrm{BeF}_{2}+\mathrm{H}_{2} \mathrm{O}_{(\mathrm{g})}$} \\
\hline & $\Delta \mathrm{H}$ & $\Delta \mathrm{S}$ & $\Delta \mathrm{G}$ & $\Delta \mathrm{H}$ & $\Delta S$ & $\Delta \mathrm{G}$ \\
\hline & $\mathrm{kJ} / \mathrm{mol} \mathrm{F}$ & $\mathrm{J} / \mathrm{K} / \mathrm{mol} \mathrm{F}$ & $\mathrm{kJ} / \mathrm{mol} \mathrm{F}$ & $\mathrm{kJ} / \mathrm{mol} \mathrm{F}$ & $\mathrm{J} / \mathrm{K} / \mathrm{mol} \mathrm{F}$ & $\mathrm{kJ} / \mathrm{mol} \mathrm{F}$ \\
\hline 100 & -164.4 & 17.5 & -171.0 & -56.3 & -59.3 & -34.23 \\
\hline 200 & -163.7 & 19.2 & -172.8 & -56.0 & -58.8 & -28.3 \\
\hline 300 & -163.3 & 20.0 & -174.8 & -55.7 & -57.9 & -22.5 \\
\hline 400 & -163.2 & 20.2 & -176.8 & -55.5 & -57.6 & -16.7 \\
\hline 500 & -163.1 & 20.3 & -178.8 & -55.3 & -57.3 & -11.0 \\
\hline 600 & -160.4 & 23.5 & -181.0 & -52.4 & -53.8 & -5.4 \\
\hline 700 & -160.0 & 24.0 & -183.4 & -51.6 & -53.0 & -0.1 \\
\hline 800 & -159.4 & 24.6 & -185.8 & -50.7 & -52.1 & 5.190 \\
\hline 900 & -158.7 & 25.2 & -188.3 & -49.7 & -51.2 & 10.353 \\
\hline 1000 & -158.0 & 25.8 & -190.8 & -48.5 & -50.2 & 15.423 \\
\hline
\end{tabular}

Table 6.2. Calculated Thermodynamic Values for Fluorination of $\mathrm{BeO}$ by $\mathrm{NF}_{3}$ Producing $\mathrm{NO}_{\mathrm{x}}$

\begin{tabular}{ccccccc}
\hline & \multicolumn{3}{c}{$3 \mathrm{BeO}+2 \mathrm{NF}_{3(\mathrm{~g})}=3 \mathrm{BeF}_{2}+\mathrm{NO}_{(\mathrm{g})}+\mathrm{NO}_{2(\mathrm{~g})}$} & \multicolumn{3}{c}{$6 \mathrm{BeO}+4 \mathrm{NF}_{3(\mathrm{~g})}=6 \mathrm{BeF}_{2}+4 \mathrm{NO}_{(\mathrm{g})}+\mathrm{O}_{2(\mathrm{~g})}$} \\
\cline { 2 - 7 } $\mathrm{T},{ }^{\circ} \mathrm{C}$ & $\begin{array}{c}\Delta \mathrm{H}, \\
\mathrm{kJ} / \mathrm{mol} \mathrm{F}\end{array}$ & $\begin{array}{c}\Delta \mathrm{S}, \\
\mathrm{J} / \mathrm{K} / \mathrm{mol} \mathrm{F}\end{array}$ & $\begin{array}{c}\Delta \mathrm{G}, \\
\mathrm{kJ} / \mathrm{mol} \mathrm{F}\end{array}$ & $\begin{array}{c}\Delta \mathrm{H}, \\
\mathrm{kJ} / \mathrm{mol} \mathrm{F}\end{array}$ & $\begin{array}{c}\Delta \mathrm{S}, \\
\mathrm{J} / \mathrm{K} / \mathrm{mol} \mathrm{F}\end{array}$ & $\begin{array}{c}\Delta \mathrm{G}, \\
\mathrm{kJ} / \mathrm{mol} \mathrm{F}\end{array}$ \\
\hline 100 & -143.9 & 9.3 & -147.4 & -134.3 & 21.7 & -142.4 \\
200 & -143.3 & 10.7 & -148.4 & -133.6 & 23.3 & -144.6 \\
300 & -142.9 & 11.5 & -149.5 & -133.2 & 24.2 & -147.0 \\
400 & -142.8 & 11.7 & -150.7 & -133.1 & 24.4 & -149.5 \\
500 & -142.7 & 11.8 & -151.8 & -133.0 & 24.5 & -151.9 \\
600 & -140.0 & 15.1 & -153.2 & -130.3 & 27.7 & -154.5 \\
700 & -139.5 & 15.6 & -154.7 & -129.8 & 28.3 & -157.3 \\
800 & -138.9 & 16.2 & -156.3 & -129.2 & 28.8 & -160.2 \\
900 & -138.2 & 16.9 & -158.0 & -128.5 & 29.4 & -163.1 \\
1000 & -137.4 & 17.5 & -159.7 & -127.8 & 30.0 & -166.1 \\
\hline
\end{tabular}

Table 6.1 shows that for the reaction of $\mathrm{HF}$ with $\mathrm{BeO}$, the $\Delta \mathrm{G}$ increases as the temperature increases until it is above $700^{\circ} \mathrm{C}$, then $\Delta \mathrm{G}$ becomes slightly positive indicating that the reaction becomes unfavorable. The small $\Delta \mathrm{G}$ above $700^{\circ} \mathrm{C}$ in combination with $\Delta \mathrm{H}$ remaining negative as temperature increases indicates that by removing the product water and/or using excess reactant HF, the reaction can 
be driven to occur. Thus in comparison, $\mathrm{NF}_{3}$ is the better agent for eliminating $\mathrm{BeO}$ from flibe independent of the reaction pathway.

As shown in Table 6.3, both $\mathrm{NF}_{3}$ and $\mathrm{HF}$ are strong fluorinating agents for $\mathrm{Li}_{2} \mathrm{O}$ and should effectively convert contaminant $\mathrm{Li}_{2} \mathrm{O}$ to $\mathrm{LiF}$, although $\mathrm{NF}_{3}$ is the stronger of the two. The $\Delta \mathrm{G}$ results provided in Table 6.4 indicate that $\mathrm{NF}_{3}$ should be effective independent of reaction pathway. Again $\mathrm{N}_{2}$ is the thermodynamically favored product.

Table 6.3. Calculated Thermodynamic Values for Fluorination of $\mathrm{Li}_{2} \mathrm{O}$ by $\mathrm{NF}_{3}$ and $\mathrm{HF}$

\begin{tabular}{|c|c|c|c|c|c|c|}
\hline \multirow[b]{3}{*}{$\mathrm{T},{ }^{\circ} \mathrm{C}$} & \multicolumn{3}{|c|}{$3 \mathrm{Li}_{2} \mathrm{O}+2 \mathrm{NF}_{3(\mathrm{~g})}=6 \mathrm{LiF}+\mathrm{N}_{2(\mathrm{~g})}+1.5 \mathrm{O}_{2(\mathrm{~g})}$} & \multicolumn{3}{|c|}{$\mathrm{Li}_{2} \mathrm{O}+2 \mathrm{HF}_{(\mathrm{g})}=2 \mathrm{LiF}+\mathrm{H}_{2} \mathrm{O}_{(\mathrm{g})}$} \\
\hline & $\Delta \mathrm{H}$ & $\Delta \mathrm{S}$ & $\Delta \mathrm{G}$ & $\Delta \mathrm{H}$ & $\Delta S$ & $\Delta \mathrm{G}$ \\
\hline & $\mathrm{kJ} / \mathrm{mol} \mathrm{F}$ & $\mathrm{J} / \mathrm{K} / \mathrm{mol} \mathrm{F}$ & $\mathrm{kJ} / \mathrm{mol} \mathrm{F}$ & $\mathrm{kJ} / \mathrm{mol} \mathrm{F}$ & $\mathrm{J} / \mathrm{K} / \mathrm{mol} \mathrm{F}$ & $\mathrm{kJ} / \mathrm{mol} \mathrm{F}$ \\
\hline 100 & -273.5 & 14.9 & -279.1 & -165.4 & -62.0 & -142.3 \\
\hline 200 & -272.9 & 16.3 & -280.6 & -165.2 & -61.3 & -136.1 \\
\hline 300 & -272.5 & 17.1 & -282.3 & -164.8 & -60.7 & -130.0 \\
\hline 400 & -272.1 & 17.8 & -284.1 & -164.4 & -60.0 & -124.0 \\
\hline 500 & -271.8 & 18.2 & -285.9 & -163.9 & -59.4 & -118.0 \\
\hline 600 & -271.4 & 18.6 & -287.7 & -163.4 & -58.7 & -112.1 \\
\hline 700 & -271.1 & 18.9 & -289.6 & -162.8 & -58.1 & -106.3 \\
\hline 800 & -270.9 & 19.2 & -291.5 & -162.2 & -57.5 & -100.5 \\
\hline 900 & -243.5 & 43.6 & -294.7 & -134.5 & -32.8 & -96.0 \\
\hline 1000 & -243.4 & 43.7 & -299.0 & -134.0 & -32.4 & -92.8 \\
\hline
\end{tabular}

Table 6.4. Calculated Thermodynamic Values for Fluorination of $\mathrm{Li}_{2} \mathrm{O}$ by $\mathrm{NF}_{3}$ Producing $\mathrm{NO}_{\mathrm{x}}$

\begin{tabular}{cccc}
\hline & \multicolumn{3}{c}{$3 \mathrm{Li}_{2} \mathrm{O}+2 \mathrm{NF}_{3(\mathrm{~g})}=6 \mathrm{LiF}+\mathrm{NO}_{(\mathrm{g})}+\mathrm{NO}_{2(\mathrm{~g})}$} \\
\cline { 2 - 4 } $\mathrm{T},{ }^{\circ} \mathrm{C}$ & $\begin{array}{c}\Delta \mathrm{H}, \\
\mathrm{kJ} / \mathrm{mol} \mathrm{F}\end{array}$ & $\begin{array}{c}\Delta \mathrm{S}, \\
\mathrm{J} / \mathrm{K} / \mathrm{mol} \mathrm{F}\end{array}$ & $\begin{array}{c}\Delta \mathrm{G}, \\
\mathrm{kJ} / \mathrm{mol} \mathrm{F}\end{array}$ \\
\hline 100 & -253.0 & 6.6 & -255.5 \\
200 & -252.5 & 7.9 & -256.2 \\
300 & -252.1 & 8.7 & -257.0 \\
400 & -251.7 & 9.3 & -258.0 \\
500 & -251.3 & 9.8 & -258.9 \\
600 & -251.0 & 10.2 & -259.9 \\
700 & -250.7 & 10.5 & -260.9 \\
800 & -250.4 & 10.8 & -262.0 \\
900 & -223.0 & 35.2 & -264.4 \\
1000 & -222.8 & 35.4 & -267.9 \\
\hline
\end{tabular}

Table 6.5 and Table 6.6 provide the reaction thermodynamic values for the fluorination of $\mathrm{Be}(\mathrm{OH})_{2}$ with $\mathrm{NF}_{3}$ and $\mathrm{HF}$. Table 6.5 shows that both $\mathrm{HF}$ and $\mathrm{NF}_{3}$ should fluorinate $\mathrm{Be}(\mathrm{OH})_{2}$ although $\mathrm{NF}_{3}$ again is the stronger of the two fluorinating agents. Table 6.6 shows that if the reaction of $\mathrm{NF}_{3}$ with $\mathrm{Be}(\mathrm{OH})_{2}$ proceeds with the production of $\mathrm{NO}_{\mathrm{x}}$, the reaction still should occur. 
Table 6.5. Calculated Thermodynamic Values for Fluorination of $\mathrm{Be}(\mathrm{OH})_{2}$ by $\mathrm{NF}_{3}$ and $\mathrm{HF}$

\begin{tabular}{|c|c|c|c|c|c|c|}
\hline \multirow[b]{3}{*}{$\mathrm{T},{ }^{\circ} \mathrm{C}$} & \multicolumn{3}{|c|}{$3 \mathrm{Be}(\mathrm{OH})_{2}+2 \mathrm{NF}_{3(\mathrm{~g})}=\mathrm{N}_{2(\mathrm{~g})}+3 \mathrm{BeF}_{2}+3 \mathrm{H}_{2} \mathrm{O}_{(\mathrm{g})}+1.5 \mathrm{O}_{2(\mathrm{~g})}$} & \multicolumn{3}{|c|}{$\mathrm{Be}(\mathrm{OH})_{2}+2 \mathrm{HF}=\mathrm{BeF}_{2}+2 \mathrm{H}_{2} \mathrm{O}_{(\mathrm{g})}$} \\
\hline & $\Delta \mathrm{H}$ & $\Delta \mathrm{S}$ & $\Delta \mathrm{G}$ & $\Delta \mathrm{H}$ & $\Delta \mathrm{S}$ & $\Delta \mathrm{G}$ \\
\hline & $\mathrm{kJ} / \mathrm{mol} \mathrm{F}$ & $\mathrm{J} / \mathrm{K} / \mathrm{mol} \mathrm{F}$ & $\mathrm{kJ} / \mathrm{mol} \mathrm{F}$ & $\mathrm{kJ} / \mathrm{mol} \mathrm{F}$ & $\mathrm{J} / \mathrm{K} / \mathrm{mol} \mathrm{F}$ & $\mathrm{kJ} / \mathrm{mol} \mathrm{F}$ \\
\hline 100 & -139.0 & 91.7 & -173.2 & -30.9 & 14.9 & -36.4 \\
\hline 200 & -139.1 & 91.5 & -182.4 & -31.3 & 13.8 & -37.9 \\
\hline 300 & -139.6 & 90.4 & -191.5 & -32.0 & 12.6 & -39.2 \\
\hline 400 & -140.6 & 88.9 & -200.4 & -32.9 & 11.2 & -40.4 \\
\hline 500 & -141.6 & 87.6 & -209.3 & -33.7 & 10.0 & -41.4 \\
\hline 600 & -140.0 & 89.4 & -218.1 & -32.0 & 12.1 & -42.5 \\
\hline 700 & -140.7 & 88.7 & -227.0 & -32.3 & 11.7 & -43.7 \\
\hline 800 & -141.2 & 88.2 & -235.9 & -32.6 & 11.5 & -44.9 \\
\hline 900 & -141.7 & 87.8 & -244.7 & -32.6 & 11.4 & -46.0 \\
\hline 1000 & -142.0 & 87.5 & -253.4 & -32.6 & 11.4 & -47.2 \\
\hline
\end{tabular}

Table 6.6. Calculated Thermodynamic Values for Fluorination of $\mathrm{Be}(\mathrm{OH})_{2}$ by $\mathrm{NF}_{3}$ Producing $\mathrm{NO}_{x}$

\begin{tabular}{cccc}
\hline & \multicolumn{3}{c}{$3 \mathrm{Be}(\mathrm{OH})_{2}+2 \mathrm{NF}_{(\mathrm{g})}=3 \mathrm{BeF}_{2}+3 \mathrm{H}_{2} \mathrm{O}_{(\mathrm{g})}+\mathrm{NO}_{(\mathrm{g})}+\mathrm{NO}_{2(\mathrm{~g})}$} \\
\cline { 2 - 4 } $\mathrm{T},{ }^{\circ} \mathrm{C}$ & $\begin{array}{c}\Delta \mathrm{H}, \\
\mathrm{kJ} / \mathrm{mol} \mathrm{F}\end{array}$ & $\begin{array}{c}\Delta \mathrm{S}, \\
\mathrm{J} / \mathrm{K} / \mathrm{mol} \mathrm{F}\end{array}$ & $\begin{array}{c}\Delta \mathrm{G}, \\
\mathrm{kJ} / \mathrm{mol} \mathrm{F}\end{array}$ \\
\hline 100 & -118.5 & 83.5 & -149.6 \\
200 & -118.6 & 83.1 & -157.9 \\
300 & -119.2 & 82.0 & -166.2 \\
400 & -120.2 & 80.5 & -174.3 \\
500 & -121.1 & 79.1 & -182.3 \\
600 & -119.6 & 81.0 & -190.3 \\
700 & -120.2 & 80.3 & -198.4 \\
800 & -120.7 & 79.8 & -206.4 \\
900 & -121.1 & 79.5 & -214.3 \\
1000 & -121.4 & 79.2 & -222.3 \\
\hline
\end{tabular}

As indicated by the calculated thermodynamic values in Table 6.7 and Table 6.8 , both $\mathrm{NF}_{3}$ and $\mathrm{HF}$ should be effective agents for fluorinating $\mathrm{LiOH}$ independent of the reaction pathway. The thermodynamic values indicate that $\mathrm{NF}_{3}$ should be the superior fluorinating agent.

Table 6.7. Calculated Thermodynamic Values for Fluorination of $\mathrm{LiOH}$ by $\mathrm{NF}_{3}$ and $\mathrm{HF}$

\begin{tabular}{ccccccc}
\hline & \multicolumn{2}{c}{$6 \mathrm{LiOH}+2 \mathrm{NF}_{3(\mathrm{~g})}=6 \mathrm{LiF}+3 \mathrm{H}_{2} \mathrm{O}_{(\mathrm{g})}+\mathrm{N}_{2(\mathrm{~g})}+1.5 \mathrm{O}_{2(\mathrm{~g})}$} & \multicolumn{3}{c}{$\mathrm{LiOH}+\mathrm{HF}_{(\mathrm{g})}=\mathrm{LiF}+\mathrm{H}_{2} \mathrm{O}_{(\mathrm{g})}$} \\
\cline { 2 - 7 } $\mathrm{T},{ }^{\circ} \mathrm{C}$ & $\Delta \mathrm{H}$ & $\Delta \mathrm{S}$ & \multicolumn{1}{c}{$\Delta \mathrm{H}$} & \multicolumn{1}{c}{$\Delta \mathrm{S}$} & \multicolumn{1}{c}{$\Delta$} \\
\cline { 2 - 7 } 100 & $\mathrm{~kJ} / \mathrm{mol} \mathrm{F}$ & $\mathrm{J} / \mathrm{K} / \mathrm{mol} \mathrm{F}$ & $\mathrm{kJ} / \mathrm{mol} \mathrm{F}$ & $\mathrm{kJ} / \mathrm{mol} \mathrm{F}$ & $\mathrm{J} / \mathrm{K} / \mathrm{mol} \mathrm{F}$ & $\mathrm{kJ} / \mathrm{mol} \mathrm{F}$ \\
200 & -208.9 & 84.0 & -240.2 & -100.8 & 7.1 & -103.5 \\
300 & -209.3 & 83.2 & -248.6 & -101.5 & 5.5 & -104.1 \\
400 & -210.1 & 81.6 & -256.8 & -102.4 & 3.8 & -104.6 \\
500 & -211.2 & 79.9 & -264.9 & -103.5 & 2.1 & -104.9 \\
600 & -233.6 & 49.8 & -272.1 & -125.8 & -27.8 & -104.2 \\
700 & -236.0 & 46.9 & -276.9 & -127.9 & -30.5 & -101.3 \\
800 & -238.1 & 44.5 & -281.5 & -129.8 & -32.5 & -98.1 \\
900 & -240.0 & 42.7 & -285.8 & -131.4 & -34.1 & -94.8 \\
1000 & -214.5 & 65.4 & -291.3 & -105.5 & -11.0 & -92.6 \\
\hline
\end{tabular}


Table 6.8. Calculated Thermodynamic Values for Fluorination of $\mathrm{LiOH}$ by $\mathrm{NF}_{3}$ Producing $\mathrm{NO}_{\mathrm{x}}$

\begin{tabular}{cccc}
\hline & \multicolumn{2}{c}{$6 \mathrm{LiOH}+2 \mathrm{NF}_{3(\mathrm{~g})}=6 \mathrm{LiF}+3 \mathrm{H}_{2} \mathrm{O}_{(\mathrm{g})}+\mathrm{NO}_{(\mathrm{g})}+\mathrm{NO}_{2(\mathrm{~g})}$} \\
\cline { 2 - 4 } $\mathrm{T},{ }^{\circ} \mathrm{C}$ & $\Delta \mathrm{H}$, & $\Delta \mathrm{S}$, & $\Delta \mathrm{G}$, \\
$\mathrm{kJ} / \mathrm{mol} \mathrm{F}$ & $\mathrm{J} / \mathrm{K} / \mathrm{mol} \mathrm{F}$ & $\mathrm{kJ} / \mathrm{mol} \mathrm{F}$ \\
\hline 100 & -188.4 & 75.7 & -216.7 \\
200 & -188.8 & 74.7 & -224.2 \\
300 & -189.7 & 73.2 & -231.6 \\
400 & -190.8 & 71.4 & -238.8 \\
500 & -213.1 & 41.3 & -245.1 \\
600 & -215.5 & 38.4 & -249.1 \\
700 & -217.7 & 36.1 & -252.8 \\
800 & -219.5 & 34.3 & -256.3 \\
900 & -194.0 & 57.1 & -260.9 \\
1000 & -195.3 & 56.9 & -266.6 \\
\hline
\end{tabular}

Our thermodynamic calculations indicate that the potential oxide and hydrolysis contaminants in flibe should be effectively fluorinated by $\mathrm{NF}_{3}$ and $\mathrm{HF}$, although $\mathrm{HF}$ 's effectiveness is significantly dependent on the temperature for $\mathrm{BeO}$. Above $700^{\circ} \mathrm{C}$, the free energy for the reaction of $\mathrm{HF}$ with $\mathrm{BeO}$ becomes slightly positive, indicating that it will be necessary to increase the HF concentration above stoichiometric requirements or remove the water product from the equilibrium zone. The free energy calculations find that $\mathrm{NF}_{3}$ should be the more effective fluorinating agent than $\mathrm{HF}$ in particular for the primary contaminant $\mathrm{BeO}$.

\subsection{Flinak}

In this section, we provide the calculated thermodynamic values for reactions of $\mathrm{NF}_{3}$ and $\mathrm{HF}$ with sodium oxide $\left(\mathrm{Na}_{2} \mathrm{O}\right)$, sodium hydroxide $(\mathrm{NaOH})$, potassium oxide $\left(\mathrm{K}_{2} \mathrm{O}\right)$, and potassium hydroxide. The thermodynamic values for reactions with $\mathrm{Li}_{2} \mathrm{O}$ and $\mathrm{LiOH}$ were provided previously in Table 6.3, Table 6.4, Table 6.7, and Table 6.8 in the section on flibe.

Based on the $\Delta$ Gs provided in Table 6.9 and Table 6.10, both $\mathrm{NF}_{3}$ and $\mathrm{HF}$ should be effective fluorinating agents for $\mathrm{Na}_{2} \mathrm{O}$ independent of temperature and the reaction pathway followed by the reaction with $\mathrm{NF}_{3}$. In comparison to $\mathrm{HF}, \mathrm{NF}_{3}$ has the more favorable thermodynamic properties.

Table 6.9. Calculated Thermodynamic Values for Fluorination of $\mathrm{Na}_{2} \mathrm{O}$ by $\mathrm{NF}_{3}$ and $\mathrm{HF}$

\begin{tabular}{|c|c|c|c|c|c|c|}
\hline \multirow[b]{3}{*}{$\mathrm{T},{ }^{\circ} \mathrm{C}$} & \multicolumn{3}{|c|}{$3 \mathrm{Na}_{2} \mathrm{O}+2 \mathrm{NF}_{3(\mathrm{~g})}=6 \mathrm{NaF}+\mathrm{N}_{2(\mathrm{~g})}+1.5 \mathrm{O}_{2(\mathrm{~g})}$} & \multicolumn{3}{|c|}{$\mathrm{Na}_{2} \mathrm{O}+2 \mathrm{HF}_{(\mathrm{g})}=2 \mathrm{NaF}+\mathrm{H}_{2} \mathrm{O}_{(\mathrm{g})}$} \\
\hline & $\Delta \mathrm{H}$ & $\Delta \mathrm{S}$ & $\Delta \mathrm{G}$ & $\Delta \mathrm{H}$ & $\Delta \mathrm{S}$ & $\Delta \mathrm{G}$ \\
\hline & $\mathrm{kJ} / \mathrm{mol} \mathrm{F}$ & $\mathrm{J} / \mathrm{K} / \mathrm{mol} \mathrm{F}$ & $\mathrm{kJ} / \mathrm{mol} \mathrm{F}$ & $\mathrm{kJ} / \mathrm{mol} \mathrm{F}$ & $\mathrm{J} / \mathrm{K} / \mathrm{mol} \mathrm{F}$ & $\mathrm{kJ} / \mathrm{mol} \mathrm{F}$ \\
\hline 100 & -324.8 & 11.1 & -328.9 & -216.7 & -65.8 & -192.2 \\
\hline 200 & -324.6 & 11.5 & -330.1 & -216.8 & -66.1 & -185.6 \\
\hline 300 & -324.6 & 11.4 & -331.2 & -217.0 & -66.4 & -178.9 \\
\hline 400 & -324.8 & 11.2 & -332.3 & -217.1 & -66.6 & -172.3 \\
\hline 500 & -325.0 & 11.0 & -333.4 & -217.1 & -66.6 & -165.6 \\
\hline 600 & -325.1 & 10.8 & -334.5 & -217.1 & -66.5 & -159.0 \\
\hline 700 & -325.2 & 10.7 & -335.6 & -216.9 & -66.4 & -152.3 \\
\hline 800 & -326.1 & 9.8 & -336.6 & -217.5 & -66.9 & -145.6 \\
\hline 900 & -326.0 & 9.9 & -337.6 & -217.0 & -66.5 & -139.0 \\
\hline 1000 & -298.3 & 31.6 & -338.6 & -188.9 & -44.5 & -132.3 \\
\hline
\end{tabular}


Table 6.10. Calculated Thermodynamic Values for Fluorination of $\mathrm{Na}_{2} \mathrm{O}$ by $\mathrm{NF}_{3}$ Producing $\mathrm{NO}_{x}$

\begin{tabular}{cccc}
\hline & \multicolumn{3}{c}{$3 \mathrm{Na}_{2} \mathrm{O}+2 \mathrm{NF}_{3(\mathrm{~g})}=6 \mathrm{NaF}+\mathrm{NO}_{(\mathrm{g})}+\mathrm{NO}_{2(\mathrm{~g})}$} \\
\cline { 2 - 4 } $\mathrm{T},{ }^{\circ} \mathrm{C}$ & $\Delta \mathrm{H}$, & $\Delta \mathrm{S}$, & $\Delta \mathrm{G}$, \\
$\mathrm{JJ} / \mathrm{K} / \mathrm{mol} \mathrm{F}$ & -305.3 \\
\hline 100 & -304.3 & 2.8 & -305.6 \\
200 & -304.2 & 3.1 & -305.9 \\
300 & -304.2 & 3.0 & -306.2 \\
400 & -304.4 & 2.8 & -306.5 \\
500 & -304.5 & 2.5 & -306.7 \\
600 & -304.7 & 2.3 & -307.0 \\
700 & -304.8 & 2.3 & -307.2 \\
800 & -305.6 & 1.4 & -307.3 \\
900 & -305.5 & 1.6 & -307.4 \\
1000 & -277.8 & 23.3 &
\end{tabular}

Based on the $\Delta$ Gs provided in Table 6.11 and Table 6.12, both $\mathrm{NF}_{3}$ and HF should be effective fluorinating agents for $\mathrm{NaOH}$ independent of temperature and the reaction pathway followed by the reaction with $\mathrm{NF}_{3}$. In comparison to $\mathrm{HF}, \mathrm{NF}_{3}$ has the more favorable $\Delta \mathrm{G}$.

Table 6.11. Calculated Thermodynamic Values for Fluorination of $\mathrm{NaOH}$ by $\mathrm{NF}_{3}$ and $\mathrm{HF}$

\begin{tabular}{|c|c|c|c|c|c|c|}
\hline \multirow[b]{3}{*}{$\mathrm{T},{ }^{\circ} \mathrm{C}$} & \multicolumn{3}{|c|}{$6 \mathrm{NaOH}+2 \mathrm{NF}_{3(\mathrm{~g})}=6 \mathrm{NaF}+3 \mathrm{H}_{2} \mathrm{O}_{(\mathrm{g})}+\mathrm{N}_{2(\mathrm{~g})}+1.5 \mathrm{O}_{2(\mathrm{~g})}$} & \multicolumn{3}{|c|}{$\mathrm{NaOH}+\mathrm{HF}_{(\mathrm{g})}=\mathrm{NaF}+\mathrm{H}_{2} \mathrm{O}_{(\mathrm{g})}$} \\
\hline & $\Delta \mathrm{H}$ & $\Delta S$ & $\Delta \mathrm{G}$ & $\Delta \mathrm{H}$ & $\Delta \mathrm{S}$ & $\Delta \mathrm{G}$ \\
\hline & $\mathrm{kJ} / \mathrm{mol} \mathrm{F}$ & $\mathrm{J} / \mathrm{K} / \mathrm{mol} \mathrm{F}$ & $\mathrm{kJ} / \mathrm{mol} \mathrm{F}$ & $\mathrm{kJ} / \mathrm{mol} \mathrm{F}$ & $\mathrm{J} / \mathrm{K} / \mathrm{mol} \mathrm{F}$ & $\mathrm{kJ} / \mathrm{mol} \mathrm{F}$ \\
\hline 100 & -228.1 & 76.7 & -256.7 & 120.0 & -0.2 & -120.0 \\
\hline 200 & -229.2 & 74.1 & -264.2 & -121.4 & -3.6 & -119.8 \\
\hline 300 & -231.5 & 69.7 & -271.5 & -123.8 & -8.1 & -119.2 \\
\hline 400 & -240.4 & 54.9 & -277.4 & -132.7 & -22.9 & -117.3 \\
\hline 500 & -242.8 & 51.6 & -282.7 & -135.0 & -26.0 & -114.8 \\
\hline 600 & -244.9 & 49.0 & -287.7 & -136.9 & -28.3 & -112.1 \\
\hline 700 & -246.8 & 47.0 & -292.5 & -138.4 & -30.1 & -109.2 \\
\hline 800 & -248.4 & 45.4 & -297.1 & -139.7 & -31.3 & -106.1 \\
\hline 900 & -249.7 & 44.2 & -301.6 & -140.7 & -32.2 & -103.0 \\
\hline 1000 & -217.4 & 69.6 & -306.1 & -108.0 & -6.4 & -99.8 \\
\hline
\end{tabular}

Table 6.12. Calculated Thermodynamic Values for Fluorination of $\mathrm{NaOH}$ by $\mathrm{NF}_{3}$ Producing $\mathrm{NO}_{\mathrm{x}}$

\begin{tabular}{cccc}
\hline & \multicolumn{3}{c}{$6 \mathrm{NaOH}+2 \mathrm{NF}_{3(\mathrm{~g})}=6 \mathrm{NaF}+\mathrm{NO}_{(\mathrm{g})}+\mathrm{NO}_{2(\mathrm{~g})}+3 \mathrm{H}_{2} \mathrm{O}_{(\mathrm{g})}$} \\
\cline { 2 - 4 } $\mathrm{T},{ }^{\circ} \mathrm{C}$ & \multicolumn{4}{c}{$\mathrm{H}}$, & $\Delta \mathrm{S}$, & $\Delta \mathrm{G}$, \\
$\mathrm{kJ} / \mathrm{mol} \mathrm{F}$ & 68.4 & -233.1 \\
\hline 100 & -207.6 & 65.6 & -239.8 \\
200 & -208.8 & 61.3 & -246.2 \\
300 & -211.1 & 46.4 & -251.2 \\
400 & -220.0 & 43.1 & -255.7 \\
500 & -222.4 & 40.6 & -259.9 \\
600 & -224.5 & 38.6 & -263.8 \\
700 & -226.3 & 37.0 & -267.6 \\
800 & -227.9 & 35.9 & -271.3 \\
900 & -229.2 & 61.3 & -274.9 \\
1000 & -196.8 & &
\end{tabular}


Based on the $\Delta$ Gs provided in Table 6.13 and Table 6.14 , both $\mathrm{NF}_{3}$ and $\mathrm{HF}$ should be effective fluorinating agents for $\mathrm{K}_{2} \mathrm{O}$ independent of temperature and the reaction pathway followed by the reaction with $\mathrm{NF}_{3}$. In comparison to $\mathrm{HF}, \mathrm{NF}_{3}$ has the more favorable $\Delta \mathrm{G}$.

Table 6.13. Calculated Thermodynamic Values for Fluorination of $\mathrm{K}_{2} \mathrm{O}$ by $\mathrm{NF}_{3}$ and $\mathrm{HF}$

\begin{tabular}{|c|c|c|c|c|c|c|}
\hline \multirow[b]{3}{*}{$\mathrm{T},{ }^{\circ} \mathrm{C}$} & \multicolumn{3}{|c|}{$3 \mathrm{~K}_{2} \mathrm{O}+2 \mathrm{NF}_{3(\mathrm{~g})}=6 \mathrm{KF}+\mathrm{N}_{2(\mathrm{~g})}+1.5 \mathrm{O}_{2(\mathrm{~g})}$} & \multicolumn{3}{|c|}{$\mathrm{K} 2 \mathrm{O}+2 \mathrm{HF}_{(\mathrm{g})}=2 \mathrm{KF}+\mathrm{H}_{2} \mathrm{O}_{(\mathrm{g})}$} \\
\hline & $\Delta \mathrm{H}$ & $\Delta \mathrm{S}$ & $\Delta \mathrm{G}$ & $\Delta \mathrm{H}$ & $\Delta \mathrm{S}$ & $\Delta \mathrm{G}$ \\
\hline & $\mathrm{kJ} / \mathrm{mol} \mathrm{F}$ & $\mathrm{J} / \mathrm{K} / \mathrm{mol} \mathrm{F}$ & $\mathrm{kJ} / \mathrm{mol} \mathrm{F}$ & $\mathrm{kJ} / \mathrm{mol} \mathrm{F}$ & $\mathrm{J} / \mathrm{K} / \mathrm{mol} \mathrm{F}$ & $\mathrm{kJ} / \mathrm{mol} \mathrm{F}$ \\
\hline 100 & -341.4 & 17.0 & -347.8 & -233.4 & $\begin{array}{l}-59.8 \\
\end{array}$ & -211.0 \\
\hline 200 & -341.3 & 17.5 & -349.5 & -233.5 & -60.1 & -205.0 \\
\hline 300 & -341.4 & 17.2 & -351.3 & -233.7 & -60.6 & -199.0 \\
\hline 400 & -344.4 & 12.6 & -352.8 & -236.7 & -65.2 & -192.8 \\
\hline 500 & -344.9 & 11.8 & -354.0 & -237.1 & -65.8 & -186.2 \\
\hline 600 & -345.3 & 11.3 & -355.2 & -237.3 & -66.0 & -179.6 \\
\hline 700 & -345.5 & 11.1 & -356.3 & -237.2 & -66.0 & -173.0 \\
\hline 800 & -359.1 & -2.3 & -356.6 & -250.4 & -79.0 & -165.6 \\
\hline 900 & -331.7 & 21.9 & -357.4 & -222.7 & -54.5 & -158.8 \\
\hline 1000 & -331.3 & 22.3 & -359.6 & -221.9 & -53.8 & -153.4 \\
\hline
\end{tabular}

Table 6.14. Calculated Thermodynamic Values for Fluorination of $\mathrm{K}_{2} \mathrm{O}$ by $\mathrm{NF}_{3}$ Producing $\mathrm{NO}_{\mathrm{x}}$

\begin{tabular}{cccc}
\hline & \multicolumn{3}{c}{$3 \mathrm{~K}_{2} \mathrm{O}+2 \mathrm{NF}_{3(\mathrm{~g})}=6 \mathrm{KF}+\mathrm{NO}_{(\mathrm{g})}+\mathrm{NO}_{2(\mathrm{~g})}$} \\
\cline { 2 - 4 } $\mathrm{T},{ }^{\circ} \mathrm{C}$ & $\Delta \mathrm{H}$, & $\Delta \mathrm{S}$, & $\Delta \mathrm{G}$, \\
$\mathrm{JJ} / \mathrm{K} / \mathrm{mol} \mathrm{F}$ & -324.2 \\
\hline 100 & -320.9 & 8.8 & -325.1 \\
200 & -320.8 & 9.1 & -326.0 \\
300 & -321.0 & 8.8 & -326.7 \\
400 & -324.0 & 4.1 & -327.1 \\
500 & -324.5 & 3.3 & -327.4 \\
600 & -324.9 & 2.9 & -327.7 \\
700 & -325.1 & 2.6 & -327.1 \\
800 & -338.6 & -10.7 & -327.1 \\
900 & -311.1 & 13.6 & -328.5 \\
1000 & -310.7 & 14.0 & \\
\hline
\end{tabular}

Based on the $\Delta$ Gs provided in Table 6.15 and Table 6.16 , both $\mathrm{NF}_{3}$ and $\mathrm{HF}$ should be effective fluorinating agents for $\mathrm{KOH}$ independent of temperature and the reaction pathway followed by the reaction with $\mathrm{NF}_{3}$. In comparison to $\mathrm{HF}, \mathrm{NF}_{3}$ has the more favorable $\Delta \mathrm{G}$.

Table 6.15. Calculated Thermodynamic Values for Fluorination of $\mathrm{KOH}$ by $\mathrm{NF}_{3}$ and $\mathrm{HF}$

\begin{tabular}{|c|c|c|c|c|c|c|}
\hline \multirow[b]{3}{*}{$\mathrm{T},{ }^{\circ} \mathrm{C}$} & \multicolumn{3}{|c|}{$6 \mathrm{KOH}+2 \mathrm{NF}_{3(\mathrm{~g})}=6 \mathrm{KF}+\mathrm{N}_{2(\mathrm{~g})}+3 \mathrm{H}_{2} \mathrm{O}_{(\mathrm{g})}+1.5 \mathrm{O}_{2(\mathrm{~g})}$} & \multicolumn{3}{|c|}{$\mathrm{KOH}+\mathrm{HF}_{(\mathrm{g})}=\mathrm{KF}+\mathrm{H}_{2} \mathrm{O}_{(\mathrm{g})}$} \\
\hline & $\Delta \mathrm{H}$ & $\Delta \mathrm{S}$ & $\Delta \mathrm{G}$ & $\Delta \mathrm{H}$ & $\Delta \mathrm{S}$ & $\Delta \mathrm{G}$ \\
\hline & $\mathrm{kJ} / \mathrm{mol} \mathrm{F}$ & $\mathrm{J} / \mathrm{K} / \mathrm{mol} \mathrm{F}$ & $\mathrm{kJ} / \mathrm{mol} \mathrm{F}$ & $\mathrm{kJ} / \mathrm{mol} \mathrm{F}$ & $\mathrm{J} / \mathrm{K} / \mathrm{mol} \mathrm{F}$ & $\mathrm{kJ} / \mathrm{mol} \mathrm{F}$ \\
\hline 100 & -220.6 & 73.5 & -248.1 & -112.5 & -3.4 & -111.3 \\
\hline 200 & -222.2 & 69.7 & -255.2 & -114.5 & -7.9 & -110.7 \\
\hline 300 & -229.8 & 55.2 & -261.4 & -122.1 & -22.7 & -109.1 \\
\hline 400 & -231.6 & 52.2 & -266.8 & -123.9 & -25.6 & -106.7 \\
\hline 500 & -241.4 & 37.9 & -270.7 & -133.6 & -39.7 & -102.9 \\
\hline 600 & -243.2 & 35.8 & -274.4 & -135.1 & -41.6 & -98.8 \\
\hline 700 & -244.7 & 34.1 & -277.9 & -136.4 & -42.9 & -94.6 \\
\hline 800 & -246.0 & 32.9 & -281.2 & -137.3 & -43.8 & -90.3 \\
\hline 900 & -219.7 & 56.1 & -285.5 & -110.7 & -20.3 & -86.9 \\
\hline 1000 & -220.4 & 55.5 & -291.1 & -111.0 & -20.5 & -84.8 \\
\hline
\end{tabular}


Table 6.16. Calculated Thermodynamic Values for Fluorination of $\mathrm{KOH}$ by $\mathrm{NF}_{3}$ Producing $\mathrm{NO}_{\mathrm{x}}$

\begin{tabular}{cccc}
\hline & \multicolumn{3}{c}{$6 \mathrm{KOH}+2 \mathrm{NF}_{3(\mathrm{~g})}=6 \mathrm{KF}+\mathrm{NO}_{(\mathrm{g})}+\mathrm{NO}_{2(\mathrm{~g})}+3 \mathrm{H}_{2} \mathrm{O}_{(\mathrm{g})}$} \\
\cline { 2 - 4 } $\mathrm{T},{ }^{\circ} \mathrm{C}$ & $\Delta \mathrm{H}$, & $\Delta \mathrm{S}$, & $\Delta \mathrm{G}$, \\
$\mathrm{kJ} / \mathrm{mol} \mathrm{F}$ & $\mathrm{J} / \mathrm{K} / \mathrm{mol} \mathrm{F}$ & -224.5 \\
100 & -200.1 & 65.2 & -230.8 \\
200 & -201.8 & 61.3 & -236.1 \\
300 & -209.4 & 46.7 & -240.6 \\
400 & -211.2 & 43.7 & -243.8 \\
500 & -221.0 & 29.4 & -246.6 \\
600 & -222.8 & 27.3 & -249.3 \\
700 & -224.2 & 25.7 & -251.8 \\
800 & -225.5 & 24.5 & -255.2 \\
900 & -199.2 & 47.8 & -260.0 \\
1000 & -199.8 & 47.2 & \\
\hline
\end{tabular}

Our thermodynamic calculations indicate that both $\mathrm{NF}_{3}$ and $\mathrm{HF}$ should effectively fluorinate the potential oxide and hydroxide contaminants in flinak. As with the potential contaminants in flibe, reactions with $\mathrm{NF}_{3}$ are more thermodynamically favorable and thus should be more effective than HF. All free energies were significant with no temperature dependencies that would prevent the reaction from proceeding or require an alternative strategy to drive the reactions.

\subsection{KF-ZrF 4}

$\mathrm{KF}-\mathrm{ZrF}_{4}$ is another secondary loop heat-transfer salt candidate. This section provides our thermodynamic calculations of the fluorination of potential zirconium oxide and hydroxide contaminants in $\mathrm{KF}_{-} \mathrm{ZrF}_{4}$. The calculations for $\mathrm{KOH}$ and $\mathrm{K}_{2} \mathrm{O}$ were presented in Table 6.13, Table 6.14, and Table 6.15 during the earlier discussion of flinak.

Based on the $\Delta$ Gs provided in Table 6.17 and Table $6.18, \mathrm{NF}_{3}$ should be an effective fluorinating agent for $\mathrm{ZrO}_{2}$ independent of temperature and whether the reaction proceeds through production of $\mathrm{N}_{2}$ or $\mathrm{NO}_{\mathrm{x}}$. In contrast, the $\Delta \mathrm{G}$ for $\mathrm{HF}$ fluorination of $\mathrm{ZrO}_{2}$ depends on temperature, with $\Delta \mathrm{G}$ becoming positive near $500^{\circ} \mathrm{C}$ and continuing to increase with increasing temperature. The $\Delta \mathrm{H}$ for the $\mathrm{HF}$ reaction remains negative up to $1000^{\circ} \mathrm{C}$. As with $\mathrm{BeO}$, to effectively fluorinate $\mathrm{ZrO}_{2}$ with $\mathrm{HF}$, the reaction above $500^{\circ} \mathrm{C}$ will have to be driven by use of excess $\mathrm{HF}$ and/or removal of the gaseous $\mathrm{H}_{2} \mathrm{O}$ product.

Table 6.17. Calculated Thermodynamic Values for Fluorination of $\mathrm{ZrO}_{2}$ by $\mathrm{NF}_{3}$ and $\mathrm{HF}$

\begin{tabular}{|c|c|c|c|c|c|c|}
\hline \multirow[b]{3}{*}{$\mathrm{T},{ }^{\circ} \mathrm{C}$} & \multicolumn{3}{|c|}{$1.5 \mathrm{ZrO}_{2}+2 \mathrm{NF}_{3(\mathrm{~g})}=1.5 \mathrm{ZrF}_{4}+\mathrm{N}_{2(\mathrm{~g})}+1.5 \mathrm{O}_{2(\mathrm{~g})}$} & \multicolumn{3}{|c|}{$\mathrm{ZrO}_{2}+4 \mathrm{HF}_{(\mathrm{g})}=\mathrm{ZrF}_{4}+2 \mathrm{H}_{2} \mathrm{O}_{(\mathrm{g})}$} \\
\hline & $\Delta \mathrm{H}$ & $\Delta \mathrm{S}$ & $\Delta \mathrm{G}$ & $\Delta \mathrm{H}$ & $\Delta \mathrm{S}$ & $\Delta \mathrm{G}$ \\
\hline & $\mathrm{kJ} / \mathrm{mol} \mathrm{F}$ & $\mathrm{J} / \mathrm{K} / \mathrm{mol} \mathrm{F}$ & $\mathrm{kJ} / \mathrm{mol} \mathrm{F}$ & $\mathrm{kJ} / \mathrm{mol} \mathrm{F}$ & $\mathrm{J} / \mathrm{K} / \mathrm{mol} \mathrm{F}$ & $\mathrm{kJ} / \mathrm{mol} \mathrm{F}$ \\
\hline 100 & -158.5 & 11.0 & -162.6 & -50.4 & -65.9 & -25.8 \\
\hline 200 & -158.2 & 11.7 & -163.7 & -50.4 & -65.9 & -19.2 \\
\hline 300 & -157.9 & 12.1 & -164.9 & -50.3 & -65.7 & -12.6 \\
\hline 400 & -157.7 & 12.5 & -166.1 & -50.0 & -65.3 & -6.1 \\
\hline 500 & -157.5 & 12.8 & -167.4 & -49.7 & -64.8 & 0.4 \\
\hline 600 & -157.2 & 13.2 & -168.7 & -49.1 & -64.1 & 6.9 \\
\hline 700 & -156.8 & 13.6 & -170.0 & -48.5 & -63.5 & 13.3 \\
\hline 800 & -156.4 & 14.0 & -171.4 & -47.8 & -62.7 & 19.6 \\
\hline 900 & -155.9 & 14.4 & -172.8 & -46.9 & -62.0 & 25.8 \\
\hline 1000 & -140.2 & 27.7 & -175.4 & -30.8 & -48.4 & 30.8 \\
\hline
\end{tabular}


Table 6.18. Calculated Thermodynamic Values for Fluorination of $\mathrm{ZrO}_{2}$ by $\mathrm{NF}_{3}$ Producing $\mathrm{NO}_{\mathrm{x}}$

\begin{tabular}{cccc}
\hline & \multicolumn{3}{c}{$1.5 \mathrm{ZrO}_{2}+2 \mathrm{NF}_{3(\mathrm{~g})}=1.5 \mathrm{ZrF}_{4}+\mathrm{NO}_{(\mathrm{g})}+\mathrm{NO}_{2(\mathrm{~g})}$} \\
\cline { 2 - 4 } $\mathrm{T},{ }^{\circ} \mathrm{C}$ & $\Delta \mathrm{H}$, & $\Delta \mathrm{S}$, & $\Delta \mathrm{G}$, \\
$\mathrm{JJ} / \mathrm{K} / \mathrm{mol} \mathrm{F}$ & 2.7 & -139.0 \\
\hline 100 & -138.0 & 3.3 & -139.3 \\
200 & -137.7 & 3.7 & -139.6 \\
300 & -137.5 & 4.0 & -140.0 \\
400 & -137.3 & 4.4 & -140.4 \\
500 & -137.1 & 4.7 & -140.9 \\
600 & -136.8 & 5.2 & -141.4 \\
700 & -136.4 & 5.6 & -141.9 \\
800 & -135.9 & 6.1 & -142.5 \\
900 & -135.4 & 19.4 & -144.3 \\
1000 & -119.6 & &
\end{tabular}

As shown in Table 6.19 and Table 6.20, both $\mathrm{NF}_{3}$ and $\mathrm{HF}$ should be effective fluorinating agents for $\mathrm{Zr}(\mathrm{OH})_{4}$ independent of temperature. In fact for both fluorinating agents the thermodynamic values improves with increasing temperature. Again, $\mathrm{NF}_{3}$ appears to be a stronger fluorinating agent than $\mathrm{HF}$ independent of whether the reaction pathway produces $\mathrm{N}_{2}$ or $\mathrm{NO}_{\mathrm{x}}$.

Table 6.19. Calculated Thermodynamic Values for Fluorination of $\mathrm{Zr}(\mathrm{OH})_{4}$ by $\mathrm{NF}_{3}$ and $\mathrm{HF}$

\begin{tabular}{lcccccc}
\hline & $1.5 \mathrm{Zr}(\mathrm{OH})_{4}+2 \mathrm{NF}_{3(\mathrm{~g})}=1.5 \mathrm{ZrF}_{4}+\mathrm{N}_{2(\mathrm{~g})}+3 \mathrm{H}_{2} \mathrm{O}_{(\mathrm{g})}+1.5 \mathrm{O}_{2(\mathrm{~g})}$ & \multicolumn{3}{c}{$\mathrm{Zr}(\mathrm{OH})_{4}+4 \mathrm{HF}_{(\mathrm{g})}=\mathrm{ZrF}_{4}+4 \mathrm{H}_{2} \mathrm{O}_{(\mathrm{g})}$} \\
\cline { 2 - 7 } $\mathrm{T},{ }^{\circ} \mathrm{C}$ & $\Delta \mathrm{H}$ & $\Delta \mathrm{S}$ & $\Delta \mathrm{G}$ & $\Delta \mathrm{H}$ & \multicolumn{1}{c}{$\Delta \mathrm{S}$} & \multicolumn{1}{c}{$\mathrm{G}$} \\
\cline { 2 - 7 } & $\mathrm{kJ} / \mathrm{mol} \mathrm{F}$ & $\mathrm{J} / \mathrm{K} / \mathrm{mol} \mathrm{F}$ & $\mathrm{kJ} / \mathrm{mol} \mathrm{F}$ & $\mathrm{kJ} / \mathrm{mol} \mathrm{F}$ & $\mathrm{J} / \mathrm{K} / \mathrm{mol} \mathrm{F}$ & $\mathrm{kJ} / \mathrm{mol} \mathrm{F}$ \\
\hline 100 & -122.1 & 92.7 & -156.7 & -14.0 & 15.9 & -19.9 \\
200 & -118.4 & 101.3 & -166.4 & -10.7 & 23.7 & -21.9 \\
400 & -114.7 & 108.4 & -176.9 & -7.1 & 30.6 & -24.6 \\
500 & -110.9 & 114.5 & -188.0 & -3.2 & 36.8 & -28.0 \\
600 & -107.0 & 120.0 & -199.8 & 0.8 & 42.4 & -31.9 \\
700 & -102.9 & 125.0 & -212.0 & 5.2 & 47.7 & -36.4 \\
800 & -98.6 & 129.6 & -224.7 & 9.7 & 52.6 & -41.4 \\
900 & -94.2 & 133.9 & -237.9 & 14.4 & 57.2 & -46.9 \\
1000 & -89.7 & 138.0 & -251.5 & 19.4 & 61.6 & -52.9 \\
\hline
\end{tabular}

Table 6.20. Calculated Thermodynamic Values for Fluorination of $\mathrm{Zr}(\mathrm{OH})_{2}$ by $\mathrm{NF}_{3}$ Producing $\mathrm{NO}_{x}$

\begin{tabular}{cccc}
\hline & \multicolumn{3}{c}{$1.5 \mathrm{Zr}(\mathrm{OH})_{4}+2 \mathrm{NF}_{3(\mathrm{~g})}=1.5 \mathrm{ZrF}_{4}+\mathrm{NO}_{(\mathrm{g})}+\mathrm{NO}_{2(\mathrm{~g})}+3 \mathrm{H}_{2} \mathrm{O}_{(\mathrm{g})}$} \\
\cline { 2 - 4 } $\mathrm{T},{ }^{\circ} \mathrm{C}$ & $\Delta \mathrm{H}$, & $\Delta \mathrm{S}$, & $\Delta \mathrm{G}$, \\
$\mathrm{JJ} / \mathrm{K} / \mathrm{mol} \mathrm{F}$ & -133.1 \\
\hline 100 & -101.6 & 84.4 & -142.0 \\
200 & -98.0 & 92.9 & -151.6 \\
300 & -94.3 & 100.0 & -161.9 \\
400 & -90.5 & 106.1 & -172.8 \\
500 & -86.6 & 111.5 & -184.2 \\
600 & -82.4 & 116.6 & -196.1 \\
700 & -78.2 & 121.2 & -208.4 \\
800 & -73.7 & 125.5 & -221.2 \\
900 & -69.1 & 129.6 & -235.5 \\
1000 & -49.2 & 146.4 &
\end{tabular}


Our thermodynamic calculations of the fluorination of $\mathrm{ZrO}_{2}$ and $\mathrm{Zr}(\mathrm{OH})_{4}$ indicate that $\mathrm{NF}_{3}$ should effectively fluorinate these two potential zirconium contaminants in $\mathrm{KF}_{-} \mathrm{ZrF}_{4}$ independent of the reaction mechanism. The $\Delta \mathrm{G}$ for $\mathrm{HF}$ fluorination of $\mathrm{Zr}(\mathrm{OH})_{4}$ also indicates that $\mathrm{HF}$ should be effective at fluorinating $\mathrm{Zr}(\mathrm{OH})_{4}$. In contrast, the $\Delta \mathrm{G}$ for the $\mathrm{HF}$ fluorination of $\mathrm{ZrO}_{2}$ becomes positive near $500^{\circ} \mathrm{C}$ and continues to increase as temperature increases to $1000^{\circ} \mathrm{C}$. The positive $\Delta \mathrm{G}$ at temperatures where the salt will be molten indicate that to effectively use HF the reaction will have to be driven by using a greater than stoichiometric amount of HF and/or rapidly removing the product gaseous water away from the reaction media.

\section{$6.4 \mathrm{KF}^{-\mathrm{KBF}_{4}}$}

$\mathrm{KF}-\mathrm{KBF}_{4}$ is another candidate salt for the heat-transfer loop. This section provides our thermodynamic calculations of the reaction of $\mathrm{NF}_{3}$ and $\mathrm{HF}$ with $\mathrm{KBO}_{2}$, a potential contaminant. Table 6.13, Table 6.14, Table 6.15 , and Table 6.16 provide our thermodynamic calculations for $\mathrm{K}_{2} \mathrm{O}$ and $\mathrm{KOH}$.

Based on the $\Delta \mathrm{Gs}$ for the reaction of $\mathrm{NF}_{3}$ with $\mathrm{KBO}_{2}, \mathrm{NF}_{3}$ should be an effective fluorinating agent for $\mathrm{KBO}_{2}$ independent of temperature and whether $\mathrm{N}_{2}$ or $\mathrm{NO}_{\mathrm{x}}$ are produced. In contrast, HF fluorination depends on the temperature with the $\Delta \mathrm{G}$ decreasing with increasing temperature and becoming positive between 900 and $1000^{\circ} \mathrm{C}$. This indicates that $\mathrm{HF}$ will be an effective fluorinating agent below $900^{\circ} \mathrm{C}$ and should be effective when operating at non-equilibrium conditions at all these temperatures.

Table 6.21. Calculated Thermodynamic Values for Fluorination of $\mathrm{KBO}_{2}$ by $\mathrm{NF}_{3}$ and $\mathrm{HF}$

\begin{tabular}{ccccccc}
\hline & \multicolumn{2}{c}{$1.5 \mathrm{KBO}_{2}+2 \mathrm{NF}_{3(\mathrm{~g})}=1.5 \mathrm{KBF}_{4}+1.5 \mathrm{O}_{2(\mathrm{~g})}+\mathrm{N}_{2(\mathrm{~g})}$} & \multicolumn{2}{c}{$\mathrm{KBO}_{2}+4 \mathrm{HF}_{(\mathrm{g})}=\mathrm{KBF}_{4}+2 \mathrm{H}_{2} \mathrm{O}_{(\mathrm{g})}$} \\
\cline { 2 - 7 } $\mathrm{T},{ }^{\circ} \mathrm{C}$ & $\Delta \mathrm{H}$ & $\Delta \mathrm{S}$ & $\Delta \mathrm{G}$ & $\Delta \mathrm{H}$ & $\Delta \mathrm{S}$ & $\Delta \mathrm{G}$ \\
\cline { 2 - 7 } 100 & $\mathrm{~kJ} / \mathrm{mol} \mathrm{F}$ & $\mathrm{J} / \mathrm{K} / \mathrm{mol} \mathrm{F}$ & $\mathrm{kJ} / \mathrm{mol} \mathrm{F}$ & $\mathrm{kJ} / \mathrm{mol} \mathrm{F}$ & $\mathrm{J} / \mathrm{K} / \mathrm{mol} \mathrm{F}$ & $\mathrm{kJ} / \mathrm{mol} \mathrm{F}$ \\
200 & -178.7 & 11.0 & -182.9 & -70.6 & -65.9 & -46.0 \\
300 & -178.2 & 12.2 & -183.9 & -70.4 & -65.4 & -39.5 \\
400 & -174.1 & 19.6 & -185.3 & -66.4 & -58.2 & -33.1 \\
500 & -173.8 & 20.0 & -187.3 & -66.2 & -57.8 & -27.3 \\
600 & -173.8 & 20.1 & -189.3 & -65.9 & -57.5 & -21.5 \\
700 & -169.2 & 25.5 & -191.5 & -61.2 & -51.8 & -15.9 \\
800 & -168.9 & 25.9 & -194.1 & -60.6 & -51.1 & -10.8 \\
900 & -168.6 & 26.1 & -196.7 & -59.9 & -50.5 & -5.7 \\
1000 & -168.4 & 26.4 & -199.3 & -59.3 & -50.0 & -0.7 \\
\hline
\end{tabular}

Table 6.22. Calculated Thermodynamic Values for Fluorination of $\mathrm{KBO}_{2}$ by $\mathrm{NF}_{3}$ Producing $\mathrm{NO}_{\mathrm{x}}$

\begin{tabular}{cccc}
\hline & \multicolumn{3}{c}{$1.5 \mathrm{KBO}_{2}+2 \mathrm{NF}_{3(\mathrm{~g})}=1.5 \mathrm{KBF}_{4}+\mathrm{NO}_{(\mathrm{g})}+\mathrm{NO}_{2(\mathrm{~g})}$} \\
\cline { 2 - 4 } $\mathrm{T},{ }^{\circ} \mathrm{C}$ & $\Delta \mathrm{H}$, & $\Delta \mathrm{S}$, & $\Delta \mathrm{G}$, \\
$\mathrm{JJ} / \mathrm{K} / \mathrm{mol} \mathrm{F}$ & 2.7 & -159.2 \\
100 & -158.1 & 3.8 & -159.5 \\
200 & -157.7 & 11.1 & -160.8 \\
300 & -153.7 & 11.5 & -161.2 \\
400 & -153.4 & 11.7 & -162.4 \\
500 & -153.4 & 17.1 & -163.7 \\
600 & -148.8 & 17.5 & -165.4 \\
700 & -148.4 & 17.8 & -167.2 \\
800 & -148.1 & 18.0 & -169.0 \\
900 & -147.8 & 11.4 & -170.4 \\
1000 & -156.0 & &
\end{tabular}




\subsection{LiF-NaF-RbF}

This section provides the calculated thermodynamic values for the $\mathrm{NF}_{3}$ and $\mathrm{HF}$ treatment of the potential rubidium oxide and hydroxide contaminants in the salt LiF-NaF-RbF; although Holcomb et al. (2009) do not identify any rubidium salts as leading candidate coolant salts, we provide this to complete the suite of salts that Williams (2006) and Williams et al. (2006) evaluated. Table 6.3, Table 6.4, Table 6.7, Table 6.8, Table 6.13, Table 6.14 , Table 6.15 , and Table 6.16 provide the thermodynamic calculations for $\mathrm{Li}_{2} \mathrm{O}, \mathrm{LiOH}, \mathrm{K}_{2} \mathrm{O}$, and $\mathrm{KOH}$.

As provided in Table 6.23 and Table 6.24 , the $\Delta$ Gs indicate that $\mathrm{NF}_{3}$ and $\mathrm{HF}$ should be strong and effective fluorinating agents for $\mathrm{RbOH}$ independent of temperatures up to $1000^{\circ} \mathrm{C}$ and independent of the $\mathrm{NF}_{3}$ reaction pathway. $\mathrm{NF}_{3}$ is more energetically favorable fluorinating agent than $\mathrm{HF}$.

Table 6.23. Calculated Thermodynamic Values for Fluorination of $\mathrm{RbOH}$ by $\mathrm{NF}_{3}$ and $\mathrm{HF}$

\begin{tabular}{ccccccc}
\hline & \multicolumn{2}{c}{$3 \mathrm{RbOH}^{2}+2 \mathrm{NF}_{3(\mathrm{~g})}=3 \mathrm{RbF}+1.5 \mathrm{O}_{2(\mathrm{~g})}+\mathrm{N}_{2(\mathrm{~g})}+3 \mathrm{HF}_{(\mathrm{g})}$} & \multicolumn{3}{c}{$\mathrm{RbOH}+\mathrm{HF}_{(\mathrm{g})}=\mathrm{RbF}+\mathrm{H}_{2} \mathrm{O}_{(\mathrm{g})}$} \\
\cline { 2 - 7 } $\mathrm{T},{ }^{\circ} \mathrm{C}$ & $\Delta \mathrm{H}$ & $\Delta \mathrm{S}$ & $\Delta \mathrm{G}$ & \multicolumn{1}{c}{$\Delta \mathrm{H}$} & \multicolumn{1}{c}{$\Delta \mathrm{S}$} & \multicolumn{1}{c}{$\mathrm{G}$} \\
\cline { 2 - 7 } 100 & $\mathrm{~kJ} / \mathrm{mol} \mathrm{F}$ & $\mathrm{J} / \mathrm{K} / \mathrm{mol} \mathrm{F}$ & $\mathrm{kJ} / \mathrm{mol} \mathrm{F}$ & $\mathrm{kJ} / \mathrm{mol} \mathrm{F}$ & $\mathrm{J} / \mathrm{K} / \mathrm{mol} \mathrm{F}$ & $\mathrm{kJ} / \mathrm{mol} \mathrm{F}$ \\
200 & -163.3 & 74.6 & -191.2 & -110.5 & -4.5 & -108.8 \\
300 & -163.8 & 73.5 & -198.6 & -112.1 & -8.3 & -108.2 \\
400 & -167.2 & 66.9 & -205.5 & -119.0 & -21.9 & -106.5 \\
500 & -171.8 & 59.9 & -212.1 & -128.2 & -35.8 & -104.0 \\
600 & -172.6 & 58.8 & -218.0 & -129.5 & -37.7 & -100.4 \\
700 & -173.3 & 57.9 & -223.8 & -130.4 & -38.8 & -96.5 \\
800 & -173.9 & 57.3 & -229.6 & -131.1 & -39.5 & -92.6 \\
900 & -161.4 & 68.9 & -235.4 & -105.5 & -15.6 & -88.8 \\
1000 & -161.7 & 68.6 & -242.2 & -105.5 & -15.6 & -87.2 \\
& -162.1 & 68.3 & -249.1 & -105.3 & -15.5 & -85.6 \\
\hline
\end{tabular}

Table 6.24. Calculated Thermodynamic Values for Fluorination of $\mathrm{RbOH}$ by $\mathrm{NF}_{3}$ Producing $\mathrm{NO}_{\mathrm{x}}$

\begin{tabular}{|c|c|c|c|}
\hline \multirow[b]{2}{*}{$\mathrm{T},{ }^{\circ} \mathrm{C}$} & \multicolumn{3}{|c|}{$6 \mathrm{RbOH}+2 \mathrm{NF}_{3(\mathrm{~g})}=6 \mathrm{RbF}+\mathrm{NO}_{(\mathrm{g})}+\mathrm{NO}_{2(\mathrm{~g})}+3 \mathrm{H}_{2} \mathrm{O}_{(\mathrm{g})}$} \\
\hline & $\underset{\mathrm{kJ} / \mathrm{mol} \mathrm{F}}{\Delta \mathrm{H}}$ & $\begin{array}{c}\Delta \mathrm{S} \\
\mathrm{J} / \mathrm{K} / \mathrm{mol} \mathrm{F}\end{array}$ & $\underset{\mathrm{kJ} / \mathrm{mol} \mathrm{F}}{\Delta \mathrm{G},}$ \\
\hline 100 & -197.2 & 67.0 & -215.5 \\
\hline 200 & -198.1 & 64.1 & -222.0 \\
\hline 300 & -199.4 & 60.9 & -228.3 \\
\hline 400 & -206.3 & 47.5 & -233.5 \\
\hline 500 & -215.4 & 33.5 & -238.0 \\
\hline 600 & -216.9 & 31.5 & -241.2 \\
\hline 700 & -218.1 & 30.0 & -244.3 \\
\hline 800 & -218.9 & 29.1 & -247.3 \\
\hline 900 & -193.6 & 52.7 & -250.3 \\
\hline 1000 & -193.9 & 52.5 & -255.5 \\
\hline
\end{tabular}

The $\Delta \mathrm{Gs}$ for the reactions of $\mathrm{NF}_{3}$ and $\mathrm{HF}$ with $\mathrm{Rb}_{2} \mathrm{O}$ indicate that these two fluorinating agents should be effective independent of temperature and whether $\mathrm{N}_{2}$ or $\mathrm{NO}_{\mathrm{x}}$ are produced by $\mathrm{NF}_{3}$ fluorination (see Table 6.25 and Table 6.26). The thermodynamic values indicate that $\mathrm{NF}_{3}$ is the more energetically favorable fluorinating agent. 
Table 6.25. Calculated Thermodynamic Values for Fluorination of $\mathrm{Rb}_{2} \mathrm{O}$ by $\mathrm{NF}_{3}$ and $\mathrm{HF}$

\begin{tabular}{ccccccc}
\hline & \multicolumn{2}{c}{$3 \mathrm{Rb}_{2} \mathrm{O}+2 \mathrm{NF}_{3(\mathrm{~g})}=6 \mathrm{RbF}+\mathrm{N}_{2(\mathrm{~g})}+1.5 \mathrm{O}_{2(\mathrm{~g})}$} & \multicolumn{2}{c}{$\mathrm{Rb}_{2} \mathrm{O}+2 \mathrm{HF}_{(\mathrm{g})}=2 \mathrm{RbF}+\mathrm{H}_{2} \mathrm{O}_{(\mathrm{g})}$} \\
\cline { 2 - 7 } $\mathrm{T},{ }^{\circ} \mathrm{C}$ & $\Delta \mathrm{H}$ & $\Delta \mathrm{S}$ & $\Delta \mathrm{G}$ & $\Delta \mathrm{H}$ & $\Delta \mathrm{S}$ & $\Delta \mathrm{G}$ \\
\cline { 2 - 7 } 100 & $\mathrm{~kJ} / \mathrm{mol} \mathrm{F}$ & $\mathrm{J} / \mathrm{K} / \mathrm{mol} \mathrm{F}$ & $\mathrm{kJ} / \mathrm{mol} \mathrm{F}$ & $\mathrm{kJ} / \mathrm{mol} \mathrm{F}$ & $\mathrm{J} / \mathrm{K} / \mathrm{mol} \mathrm{F}$ & $\mathrm{kJ} / \mathrm{mol} \mathrm{F}$ \\
200 & -346.3 & 12.9 & -351.1 & -238.2 & -64.0 & -214.4 \\
300 & -346.0 & 13.7 & -352.5 & -238.2 & -64.0 & -208.0 \\
400 & -346.4 & 12.9 & -353.8 & -238.8 & -64.9 & -201.6 \\
500 & -348.7 & 9.2 & -354.9 & -241.0 & -68.6 & -194.8 \\
600 & -348.8 & 9.1 & -355.8 & -240.9 & -68.5 & -188.0 \\
700 & -358.6 & -3.5 & -355.5 & -250.5 & -80.9 & -180.0 \\
800 & -358.2 & -3.1 & -355.2 & -249.9 & -80.1 & -171.9 \\
900 & -331.7 & 21.7 & -355.0 & -223.1 & -55.0 & -164.0 \\
1000 & -330.9 & 22.4 & -357.2 & -221.9 & -54.0 & -158.6 \\
\hline
\end{tabular}

Table 6.26. Calculated Thermodynamic Values for Fluorination of $\mathrm{Rb}_{2} \mathrm{O}$ by $\mathrm{NF}_{3}$ Producing $\mathrm{NO}_{\mathrm{x}}$

\begin{tabular}{|c|c|c|c|}
\hline \multirow[b]{2}{*}{$\mathrm{T},{ }^{\circ} \mathrm{C}$} & \multicolumn{3}{|c|}{$3 \mathrm{Rb}_{2} \mathrm{O}+2 \mathrm{NF}_{3(\mathrm{~g})}=6 \mathrm{RbF}+\mathrm{NO}_{(\mathrm{g})}+\mathrm{NO}_{2(\mathrm{~g})}$} \\
\hline & $\begin{array}{c}\Delta \mathrm{H}, \\
\mathrm{kJ} / \mathrm{mol} \mathrm{F}\end{array}$ & $\begin{array}{c}\Delta \mathrm{S} \\
\mathrm{J} / \mathrm{K} / \mathrm{mol} \mathrm{F}\end{array}$ & $\begin{array}{c}\Delta \mathrm{G}, \\
\mathrm{kJ} / \mathrm{mol} \mathrm{F}\end{array}$ \\
\hline 100 & -325.8 & 4.6 & -327.6 \\
\hline 200 & -325.6 & 5.3 & -328.1 \\
\hline 300 & -326.0 & 4.5 & -328.6 \\
\hline 400 & -328.3 & 0.8 & -328.8 \\
\hline 500 & -328.3 & 0.7 & -328.9 \\
\hline 600 & -338.2 & -12.0 & -327.7 \\
\hline 700 & -337.7 & -11.5 & -326.5 \\
\hline 800 & -311.2 & 13.3 & -325.6 \\
\hline 900 & -310.4 & 14.1 & -326.9 \\
\hline 1000 & -309.5 & 14.8 & -328.4 \\
\hline
\end{tabular}

Our thermodynamic calculations indicate that $\mathrm{NF}_{3}$ and $\mathrm{HF}$ should be effective for removing oxide and hydroxide contaminants in LiF-NaF-RbF. Our calculations indicate that $\mathrm{NF}_{3}$ is the more thermodynamically favorable fluorinating agent.

\subsection{Fuel Components}

The planned TRISO fuel is composed of an outer pyrolytic carbon layer, silicon carbide layer, another pyrolytic carbon layer, a porous carbon buffer, and the fuel kernel that could be $\mathrm{UO}_{2}$ or another uranium compound. Because the potential exists for pieces of broken fuel to become mixed with the primary coolant, we calculated the thermodynamic values for fluorinating these materials with $\mathrm{NF}_{3}$ and $\mathrm{HF}$. The current plans are to use mechanical filters to remove the particulate materials, but each of these materials forms volatile fluorides and the fluorination strategy may merit consideration.

The production of $\mathrm{CF}_{4}$ by the action of $\mathrm{NF}_{3}$ on carbon is thermodynamically favorable as shown in Table 6.27. In contrast, treatment of carbon with $\mathrm{HF}$ should have no effect. Thus, $\mathrm{NF}_{3}$ treatment to remove carbon or graphite is a potential approach to removing graphite or carbon from flibe. 
Table 6.27. Calculated Thermodynamic Values for Fluorination of $\mathrm{C}$ by $\mathrm{NF}_{3}$ and $\mathrm{HF}$

\begin{tabular}{|c|c|c|c|c|c|c|}
\hline \multirow[b]{3}{*}{$\mathrm{T},{ }^{\circ} \mathrm{C}$} & \multicolumn{3}{|c|}{$1.5 \mathrm{C}+2 \mathrm{NF}_{3(\mathrm{~g})}=1.5 \mathrm{CF}_{4(\mathrm{~g})}+\mathrm{N}_{2(\mathrm{~g})}$} & \multicolumn{3}{|c|}{$\mathrm{C}+4 \mathrm{HF}_{(\mathrm{g})}=\mathrm{CF}_{4(\mathrm{~g})}+2 \mathrm{H}_{2(\mathrm{~g})}$} \\
\hline & $\Delta \mathrm{H}$ & $\Delta \mathrm{S}$ & $\Delta \mathrm{G}$ & $\Delta \mathrm{H}$ & $\Delta \mathrm{S}$ & $\Delta \mathrm{G}$ \\
\hline & $\mathrm{kJ} / \mathrm{mol} \mathrm{F}$ & $\mathrm{J} / \mathrm{K} / \mathrm{mol} \mathrm{F}$ & $\mathrm{kJ} / \mathrm{mol} \mathrm{F}$ & $\mathrm{kJ} / \mathrm{mol} \mathrm{F}$ & $\mathrm{J} / \mathrm{K} / \mathrm{mol} \mathrm{F}$ & $\mathrm{kJ} / \mathrm{mol} \mathrm{F}$ \\
\hline 100 & -189.4 & 8.9 & -192.7 & 39.9 & -44.7 & 56.6 \\
\hline 200 & -189.5 & 8.7 & -193.6 & 40.0 & -44.5 & 61.1 \\
\hline 300 & -189.6 & 8.4 & -194.5 & 40.2 & -44.1 & 65.5 \\
\hline 400 & -189.8 & 8.1 & -195.3 & 40.5 & -43.7 & 69.9 \\
\hline 500 & -190.0 & 7.9 & -196.1 & 40.9 & -43.2 & 74.2 \\
\hline 600 & -190.2 & 7.6 & -197.0 & 41.3 & -42.7 & 78.5 \\
\hline 700 & -190.4 & 7.4 & -197.6 & 41.7 & -42.2 & 82.8 \\
\hline 800 & -190.6 & 7.2 & -198.3 & 42.1 & -41.8 & 87.0 \\
\hline 900 & -190.8 & 7.0 & -199.1 & 42.6 & -41.4 & 91.1 \\
\hline 1000 & -191.0 & 6.8 & -199.8 & 43.0 & -41.0 & 95.3 \\
\hline
\end{tabular}

The treatment of $\mathrm{SiC}$ with $\mathrm{NF}_{3}$ or $\mathrm{HF}$ should result in the formation of gaseous $\mathrm{SiF}_{4}$ or $\mathrm{CF}_{4}$ and thus be removed from the flibe. $\mathrm{NF}_{3}$ is the thermodynamically more powerful treatment.

Table 6.28. Calculated Thermodynamic Values for Fluorination of $\mathrm{SiC}$ by $\mathrm{NF}_{3}$ and $\mathrm{HF}$

\begin{tabular}{ccccccc}
\hline & \multicolumn{2}{c}{$\mathrm{SiC}+2.667 \mathrm{NF}_{3(\mathrm{~g})}=\mathrm{SiF}_{4(\mathrm{~g})}+\mathrm{CF}_{4(\mathrm{~g})}+1.333 \mathrm{~N}_{2(\mathrm{~g})}$} & \multicolumn{3}{c}{$\mathrm{SiC}+4 \mathrm{HF}_{(\mathrm{g})}=\mathrm{SiF}_{4(\mathrm{~g})}+\mathrm{CH}_{4(\mathrm{~g})}$} \\
\cline { 2 - 7 } $\mathrm{T},{ }^{\circ} \mathrm{C}$ & $\Delta \mathrm{H}$ & $\Delta \mathrm{S}$ & $\Delta \mathrm{G}$ & $\Delta \mathrm{H}$ & $\Delta \mathrm{S}$ & $\Delta \mathrm{G}$ \\
\cline { 2 - 7 } 100 & $\mathrm{~kJ} / \mathrm{mol} \mathrm{F}$ & $\mathrm{J} / \mathrm{K} / \mathrm{mol} \mathrm{F}$ & $\mathrm{kJ} / \mathrm{mol} \mathrm{F}$ & $\mathrm{kJ} / \mathrm{mol} \mathrm{F}$ & $\mathrm{J} / \mathrm{K} / \mathrm{mol} \mathrm{F}$ & $\mathrm{kJ} / \mathrm{mol} \mathrm{F}$ \\
200 & -265.7 & 11.0 & -269.8 & -131.9 & -62.4 & -108.6 \\
300 & -265.8 & 10.8 & -270.9 & -132.5 & -63.8 & -102.3 \\
400 & -265.9 & 10.5 & -271.9 & -133.0 & -64.7 & -95.9 \\
500 & -266.1 & 10.2 & -273.0 & -133.2 & -65.1 & -89.4 \\
600 & -266.3 & 9.9 & -274.0 & -133.3 & -65.2 & -82.9 \\
700 & -266.5 & 9.7 & -275.0 & -133.3 & -65.2 & -76.4 \\
800 & -266.7 & 9.5 & -275.9 & -133.1 & -65.0 & -69.9 \\
900 & -266.9 & 9.2 & -276.8 & -132.9 & -64.8 & -63.4 \\
1000 & -267.2 & 9.0 & -277.8 & -132.7 & -64.6 & -56.9 \\
\hline
\end{tabular}

Studies by McNamara et al. (2009) at PNNL have shown that $\mathrm{NF}_{3}$ is an effective thermal fluorinating agent for various uranium compounds including $\mathrm{UO}_{2}$. Our thermodynamic calculations for $\mathrm{NF}_{3}$ - and HFfluorination provided in Table 6.29 and Table 6.30 show that the $\mathrm{NF}_{3}$ treatment should produce the volatile $\mathrm{UF}_{6}$ while the $\mathrm{HF}$ treatment should not. If deemed attractive from a process perspective, treatment with $\mathrm{NF}_{3}$ to remove $\mathrm{UO}_{2}$ particles from flibe appears to be feasible. 
Table 6.29. Calculated Thermodynamic Values for Fluorination of $\mathrm{UO}_{2}$ by $\mathrm{NF}_{3}$ and $\mathrm{HF}$

\begin{tabular}{ccccccc}
\hline & \multicolumn{2}{c}{$\mathrm{UO}_{2}+2 \mathrm{NF}_{3(\mathrm{~g})}=\mathrm{UF}_{6(\mathrm{~g})}+\mathrm{O}_{2(\mathrm{~g})}+\mathrm{N}_{2(\mathrm{~g})}$} & \multicolumn{3}{c}{$\mathrm{UO}_{2}+6 \mathrm{HF}_{(\mathrm{g})}=\mathrm{UF}_{6(\mathrm{~g})}+2 \mathrm{H}_{2} \mathrm{O}_{(\mathrm{g})}+\mathrm{H}_{2(\mathrm{~g})}$} \\
\cline { 2 - 7 } $\mathrm{T},{ }^{\circ} \mathrm{C}$ & $\Delta \mathrm{H}$ & $\Delta \mathrm{S}$ & $\mathrm{G}$ & $\Delta \mathrm{H}$ & $\Delta \mathrm{S}$ & $\Delta \mathrm{G}$ \\
\cline { 2 - 7 } 100 & $\mathrm{~kJ} / \mathrm{mol} \mathrm{F}$ & $\mathrm{J} / \mathrm{K} / \mathrm{mol} \mathrm{F}$ & $\mathrm{kJ} / \mathrm{mol} \mathrm{F}$ & $\mathrm{kJ} / \mathrm{mol} \mathrm{F}$ & $\mathrm{J} / \mathrm{K} / \mathrm{mol} \mathrm{F}$ & $\mathrm{kJ} / \mathrm{mol} \mathrm{F}$ \\
200 & -133.0 & 29.7 & -144.1 & 15.5 & -39.4 & 30.2 \\
300 & -133.0 & 29.7 & -147.1 & 15.3 & -39.8 & 34.1 \\
400 & -133.2 & 29.4 & -150.1 & 15.2 & -40.0 & 38.1 \\
500 & -133.4 & 29.0 & -153.0 & 15.1 & -40.1 & 42.1 \\
600 & -133.7 & 28.7 & -155.9 & 15.1 & -40.1 & 46.1 \\
700 & -134.0 & 28.3 & -158.7 & 15.1 & -40.0 & 50.1 \\
800 & -134.4 & 27.9 & -161.5 & 15.2 & -40.0 & 54.1 \\
900 & -134.7 & 27.6 & -164.3 & 15.3 & -39.9 & 58.1 \\
1000 & -135.1 & 27.2 & -167.0 & 15.4 & -39.8 & 62.1 \\
\hline
\end{tabular}

Table 6.30. Calculated Thermodynamic Values for Fluorination of $\mathrm{UO}_{2}$ by $\mathrm{NF}_{3}$ Producing $\mathrm{NO}_{\mathrm{x}}$

\begin{tabular}{cccc}
\hline & \multicolumn{3}{c}{$\mathrm{UO}_{2}+2 \mathrm{NF}_{3(\mathrm{~g})}=\mathrm{UF}_{6(\mathrm{~g})}+2 \mathrm{NO}_{(\mathrm{g})}$} \\
\cline { 2 - 4 } $\mathrm{T},{ }^{\circ} \mathrm{C}$ & $\begin{array}{c}\Delta \mathrm{H}, \\
\mathrm{kJ} / \mathrm{mol} \mathrm{F}\end{array}$ & $\begin{array}{c}\Delta \mathrm{S}, \\
\mathrm{J} / \mathrm{K} / \mathrm{mol} \mathrm{F}\end{array}$ & $\begin{array}{c}\Delta \mathrm{G}, \\
\mathrm{kJ} / \mathrm{mol} \mathrm{F}\end{array}$ \\
\hline 100 & -102.9 & 33.9 & -115.6 \\
200 & -102.9 & 33.9 & -119.0 \\
300 & -103.1 & 33.6 & -122.3 \\
400 & -103.3 & 33.2 & -125.7 \\
500 & -103.6 & 32.9 & -129.0 \\
600 & -103.9 & 32.5 & -132.2 \\
700 & -104.2 & 32.1 & -135.5 \\
800 & -104.6 & 31.8 & -138.7 \\
900 & -104.9 & 31.4 & -141.8 \\
1000 & -105.4 & 31.1 & -145.0 \\
\hline
\end{tabular}

Our thermodynamic calculations suggest that $\mathrm{NF}_{3}$ treatment could be used to remove fuel particle constituents from flibe if such an option is determined to be attractive from an engineering and processing perspective.

\subsection{Thermodynamics Summary}

Our thermodynamic calculations for the treatment of potential coolant and heat-transfer salt oxideand hydroxide-contaminants indicate that $\mathrm{NF}_{3}$ should be an effective fluorinating agent for each independent of temperature or reaction products. In each case, the normalized free energy associated with the reaction with $\mathrm{NF}_{3}$ is always negative (favorable) and more negative than that for the corresponding reaction with $\mathrm{HF}$. This implies that if $\mathrm{HF}$ has been used to successfully fluorinate contaminants in salt mixtures, then thermodynamically, $\mathrm{NF}_{3}$ should also successfully perform these fluorinations under similar process conditions, particularly given that the thermodynamic values of HF were not always favorable depending on temperature. For some contaminants, the free energy associated with the equation indicates that at some temperatures the fluorination reaction is favorable with $\mathrm{NF}_{3}$, while the corresponding reaction with $\mathrm{HF}$ is not. 
In each reaction considered, the volatile compounds are denoted by the $(\mathrm{g})$ identifier to indicate which compounds are expected to leave the molten salt mixture as a gas. The physical removal of the gas is not ensured however, because the solubility of compounds (including the fluorinating agents) in the salt mixtures is not well known. Incorporation of the volatile compounds within the salt mixture as a function of temperature is of interest.

Our thermodynamic calculations are indicators of thermodynamic favorability, but several additional physical parameters are necessary to fully gauge the effectiveness of the use of $\mathrm{NF}_{3}$ relative to $\mathrm{HF}$ for the salt purification. For instance, the transport of $\mathrm{NF}_{3}$ through the salt via sparging may be significantly different than the transport of HF under the same conditions. Also, only a few competing reactions were considered.

We know from our experimental studies that although it is thermodynamically favored, $\mathrm{NF}_{3}$ fluorination reactions can be multistep; for example, the reaction of $\mathrm{UO}_{2}$ with $\mathrm{NF}_{3}$ to form $\mathrm{UF}_{6}$. Although it is thermodynamically favorable to form $\mathrm{UF}_{6}$ from $\mathrm{UO}_{2}$ at all temperatures between 100 and $1000^{\circ} \mathrm{C}$, we have experimentally determined that this reaction does not proceed until reaching temperatures above $500^{\circ} \mathrm{C}$ (McNamara et al. 2009) and then through the formation of $\mathrm{UO}_{2} \mathrm{~F}_{2}$. Further study of kinetic parameters and competing reactions is necessary to fully appreciate the replacement of $\mathrm{HF}$ with $\mathrm{NF}_{3}$ for the purification of fluoride salt mixtures. 



\subsection{Financial Considerations}

The cost of $\mathrm{NF}_{3}$ use depends on of the following factors:

- the treatment strategy and the design of the treatment process and system

- the strategy for protecting staff from the chemical and reactivity hazards of the fluorinating gas.

- the strategy for controlling release of the fluorinating agent.

The current approach for salt purification sparges $\mathrm{HF} / \mathrm{H}_{2}$ through the molten salt to remove oxygenand water-caused contaminants. Because $\mathrm{NF}_{3}$ is also a gas, $\mathrm{NF}_{3}$ should be directly substitutable into the existing treatment strategy and system. HF is a highly toxic and slightly reactive gas at ambient temperatures and $\mathrm{H}_{2}$ is flammable. Because $\mathrm{NF}_{3}$ is a mildly toxic and non-reactive gas at ambient temperatures and can be managed as an oxidizing gas, the requirements for equipment to protect workers handling it should be less stringent. HF is a water-soluble gas and its release can be easily controlled using aqueous scrubbers. $\mathrm{NF}_{3}$ is not water soluble and could require more complicated emission control systems.

A full economic evaluation of the replacement of $\mathrm{HF} / \mathrm{H}_{2}$ with $\mathrm{NF}_{3}$ is beyond the scope of this report but in this section, we provide costs for $\mathrm{NF}_{3}$ and $\mathrm{HF}$ and briefly identify some of the considerations that will affect capital costs.

\subsection{Process Costs}

In small laboratory-scale quantities, $\mathrm{HF}$ can be obtained in a gas-bottle for $\$ 28.30 / \mathrm{lb}$ and $\mathrm{NF}_{3}$ can be obtained in a bottle for $\$ 64.32 / \mathrm{lb}$. Based on fluorine content, the cost is $\$ 1.25 / \mathrm{mol} \mathrm{HF}(\$ 1.25 / \mathrm{mol} \mathrm{F})$ and $\$ 10.05 / \mathrm{mol} \mathrm{NF}_{3}(\$ 3.35 / \mathrm{mol} \mathrm{F})$ or a relative cost ratio of 0.373 for $\mathrm{HF} / \mathrm{NF}_{3}$. On a larger industrial-scale, $\mathrm{NF}_{3}$ can be purchased for a price as low as $\$ 33 / \mathrm{lb}$ if it is purchased in very large bulk quantities (truck loads). All costs are in 2010 US\$.

\subsection{Capital Costs}

Capital costs will be dictated in part by equipment costs associated with the receipt, onsite transportation, storage, worker protection, reactor materials of construction, and emission control or fluorinating agent management.

$\mathrm{HF}$ is a highly corrosive, hazardous gas while $\mathrm{NF}_{3}$ can be managed only as an oxidizer. The requirements for transportation, storage, and worker protection should be significantly less for $\mathrm{NF}_{3}$.

The materials of construction used for the purification reactor must be compatible with active fluorides from the molten fluoride salts and the purification fluorinating agent. The materials of construction requirements for $\mathrm{HF}$ and $\mathrm{NF}_{3}$ are similar in that they must be resistant to active fluorine and will include nickel and nickel-based alloys. The requirements for the effluent management system for $\mathrm{NF}_{3}$ may be more rigorous than those for HF because of concerns about its GWP; a cost-benefit analysis of recycle may have merit. 



\subsection{Conclusions}

In this report we consider a number of factors that will determine the viability of $\mathrm{NF}_{3}$ as a purification agent for the molten fluoride salt coolant candidates for the FHR-TS particularly as a potential replacement for $\mathrm{HF} / \mathrm{H}_{2}$. Of importance are the chemical and reactivity hazards, operational safety, and chemical viability (thermodynamic values) of the fluorination reactions that must occur to remove the oxide and hydroxide contaminants observed and postulated to exist in these fluoride salts.

Because $\mathrm{NF}_{3}$ is only mildly toxic, non-corrosive, and non-reactive at room temperature, it will be easy to manage the chemical and reactivity hazards during transportation, storage, and normal operations. Industrial experience with $\mathrm{NF}_{3}$ is also extensive because $\mathrm{NF}_{3}$ is commonly used in the electronics industry as an etchant and chamber cleaner. In contrast HF is a highly toxic and corrosive gas at room temperature, but because of its importance as the most important fluorine-containing chemical there is significant industrial experience managing HF hazards.

$\mathrm{NF}_{3}$ has been identified as having the potential to be a significant contributor to global warming and thus its release must be evaluated and/or managed depending on the amounts that would be released. Because of its importance to the electronics industry, commercial technologies using incineration or plasmas have been developed and are being used to destroy the $\mathrm{NF}_{3}$ in a facility's gaseous effluent stream. A process has been developed and used to recover and recycle $\mathrm{NF}_{3}$. In addition the electronics industry is actively pursuing alternative methods for controlling $\mathrm{NF}_{3}$ releases. In comparison, $\mathrm{HF}$ has not been identified to be a potential global warming gas nor has it been determined to have any other environmental effects. Also, because of the high solubility of HF in water and aqueous caustic solutions, the HF industry has developed and used aqueous scrubbers to effectively prevent its release into the environment.

Care appears to be necessary when using $\mathrm{NF}_{3}$ in plants. Precautions must be taken to prevent adiabatic compression and make sure that $\mathrm{NF}_{3}$ thermal decomposition does not occur in unplanned locations. The system must be engineered to avoid the use of ball valves and sharp bends.

The materials of construction that will be required to contain $\mathrm{NF}_{3}$ and anhydrous $\mathrm{HF}$ will be similar. If water is present such as in the process effluent, $\mathrm{HF}$ is more corrosive than $\mathrm{NF}_{3}$ and its containment would require nickel or nickel-based alloys. Both of these fluorinating agents become more reactive with increasing temperature and would require nickel or nickel-based alloys for containment until the gas stream has cooled.

With respect to the cost of the fluoride, $\mathrm{HF}$ is about one third the cost of $\mathrm{NF}_{3}$. Of the fluorinecontaining chemicals, more $\mathrm{HF}$ is produced than any other. $\mathrm{NF}_{3}$ is produced on an industrial scale and its capacity has grown each year since it was identified to be a useful etchant.

Both $\mathrm{NF}_{3}$ and $\mathrm{HF}$ have been demonstrated to be effective at removing oxide, hydroxide, and water contamination from fluoride salts and during melting of fluoride glasses while $\mathrm{HF}$ in combination with $\mathrm{H}_{2}$ has been demonstrated to be effective for some of the candidate coolant salts and some of their individual constituents such as $\mathrm{BeO}$. HF has a limited solubility in molten $66 \mathrm{~mol} \% \mathrm{LiF}-33 \mathrm{~mol} \% \mathrm{BeF}_{2}$ indicating that treatment with $\mathrm{HF}$ will result in free $\mathrm{F}^{-}$in $\mathrm{HF}$-treated fluoride salts. $\mathrm{H}_{2}$ 's flammability and potential explosivity introduces additional hazards to its use. 
With respect to chemical viability as measured by reaction free energies, $\mathrm{NF}_{3}$ is a stronger fluorinating agent than HF. For all postulated contaminants the calculated free energies for treatment by $\mathrm{NF}_{3}$ were negative, indicating that the reactions were favorable and should occur provided there are no kinetic barriers. In contrast, HF's fluorinating power declined with increasing temperature, and in a couple of instances the reaction free energy became slightly positive (e.g., $\mathrm{BeO}$ above $700^{\circ} \mathrm{C}$ ), indicating that use of excess HF would be required for the fluorination to occur or that the product water would have to be removed to force the reaction to occur. Experimental studies are required to demonstrate that the predicted chemical viability is real and to determine the conditions that are necessary to remove the oxide and hydroxide contaminants.

Although the plan is to remove any broken fuel debris from the primary coolant by filtering, we evaluated the potential use of $\mathrm{NF}_{3}$ as an agent to remove the uranium, silicon carbide, and carbon using thermodynamic values. This evaluation indicates that each of these fuel constituents should be converted to volatile fluorides by $\mathrm{NF}_{3}$.

In conclusion, $\mathrm{NF}_{3}$ appears to be a viable and effective purification agent for removing oxide and hydroxide contaminants from the FHR-TS coolant salts. Experimental studies are required to determine the conditions required for the postulated purification process reactions to occur. In general, most of the complications with $\mathrm{NF}_{3}$ use can be overcome by proper engineering. However, an evaluation of the need and viability of existing technologies to control $\mathrm{NF}_{3}$ release would be required. 


\subsection{References}

Air Products and Chemicals, Inc. 2000. "Material Safety Data Sheet: Fluorine." Air Products and Chemicals, Inc. Allentown, Pennsylvania.

Air Products and Chemicals, Inc. 2007. "Air Products Boosts $\mathrm{NF}_{3}$ Capacity in US and Asia." Lehigh Valley, Pennsylvania.

Air Products and Chemicals, Inc. 2008. "Material Safety Data Sheet: Nitrogen Trifluoride." Air Products and Chemicals, Inc, Allentown, Pennsylvania.

Air Products and Chemicals, Inc. 2009. "Material Safety Data Sheet: HF." Air Products and Chemicals, Inc, Allentown, Pennsylvania.

Air Products and Chemicals, Inc. 2010a. "Nitrogen Trifluoride $\left(\mathrm{NF}_{3}\right)$ Product Stewardship Summary." Air Products and Chemicals, Inc. Allentown, Pennsylvania.

Air Products and Chemicals, Inc. 2010b. "Safetygram \#28 Nitrogen Trifluoride $\left(\mathrm{NF}_{3}\right)$." Air Products and Chemicals, Inc. Allentown, Pennsylvania.

Atkins, $\mathrm{RM}$ and $\mathrm{MM}$ Broer. 1988. "Interaction of $\mathrm{NF}_{3}$ with Melt Confinement Materials in Fluoride Glass Processing." J Material Science 3:369-74.

Baldwin, CM and JD Mackenzie. 1979. "Preparation and Properties of Water-Free Vitreous Beryllium Fluoride." Journal of Non-Crystalline Solids 31:441-45.

Barbier, J, G Bissolotti, K Cleaver, J Goffinet, B Hussler, and P Wolfs. 2010. Code of Practice Nitrogen Trifluoride. Technical Rpt. IGC Doc 92/10/E, European Industrial Gases Association, Brussels, Belgium.

BOC Gases. 2007a. "Material Safety Data Sheet: Fluorine. " Mississauga, Ontario.

BOC Gases. 2007b. "Material Safety Data Sheet: Hydrogen Fluoride." Mississauga, Ontario.

BOC Gases. 2008. "Material Safety Data Sheet: Nitrogen Trifluoride." Murray Hill, New Jersey.

Calderoni, P, P Sharpe, H Nishimura, and T Terai. 2009. "Control of Molten Salt Corrosion of Fusion Structural Materials by Metallic Beryllium." Journal of Nuclear Materials:1102-06.

Chang, J-S, KG Kostov, K Urashima, T Yamamoto, Y Okayasu, T Kato, T Iwaizumi, and K Yoshimura. 2000. "Removal of $\mathrm{NF}_{3}$ from Semiconductor-Process Flue Gases by Tandem Packed-Bed Plasma and Adsorbent Hybrid Systems." IEEE Transactions on Industry Applications, 36:1251-59.

Chen, JR. 2002. "Characteristics of Fire and Explosion in Semiconductor Fabrication Processes." Process Safety Progress 21:19-25.

de Wild-Scholten, M, E Alsema, V Fthenakis, G Agostinelli, H Dekkers, K Roth, and V Kinzig. 2007. "Fluorinated Greenhouse Gases in Photovoltaic Module Manufacturing: Potential Emissions and Abatement Strategies." In Proceedings of $22^{\text {nd }}$ European Photovoltaic Solar Energy Conference, Fiera Milano, Italy. 
Dorko, EA, UW Grimm, K Scheller, and GW Mueller. 1975. "Shock Tube Decomposition of Dilute Mixtures of Nitrogen Trifluoride in Argon." The Journal of Chemical Physics 63:3596-601.

Evans, PJ and E Tschuikow-Roux. 1976. "Thermal Decompostion of Nitrogen Trifluoride in Shock Waves." The Journal of Chemical Physics 65:4202-09.

Everest, DA. 1973. "Beryllium." In Comprehensive Inorganic Chemistry: H, Noble Gases, Group Ia, Group IIa, Group IIIb, C, and Si, eds. JC Bailar, et al., Vol 1, pp. 531-90. Pergamon Press, New York.

Field, PE and JH Shaffer. 1967. "The Solubilities of Hydrogen Fluoride and Deuterium Fluoride in Molten Fluorides." The Journal of Physical Chemistry 71:3218-22.

Gillespie, RJ and GP Pez. 1969. "Fluorosulfuric Acid Solvent System. VII. The Behavior of Some Extremely Weak Bases in the Superacid System Fluorosulfuric Acid- Antimony Pentafluoride-Sulfur Trioxide." Inorganic Chemistry 8:1233-35.

Grothaus, M and E Fanick. 1996. "Harmful Compounds Yield to Nonthermal Plasma Reactor." Technology Today, http://www.southwestreseachinstitute.net/3pubs/ttoday/Spring96/ttoday2.htm, accessed 5/25/1010, Southwest Research Institute, San Antono, Texas.

Hart, WA and OF Beumel, Jr. 1973. "Lithium and Its Compounds." In Comprehensive Inorganic Chemistry: H, Noble Gases, Group Ia, Group IIa, Group IIIb, C, and Si, eds. JC Bailar, et al., Vol 1, pp. 331-67. Pergamon Press, New York.

Henderson, PB and AJ Woytek. 2010. "Fluorine Compounds, Inorganic, Nitrogen." In Kirk-Othmer Encyclopedia of Chemical Technology. John Wiley \& Sons, Inc, New York.

Holcomb, DE, SM Centiner, GF Flanagan, FJ Peretz, and GL Yoder, Jr. 2009. An Analysis of Testing Requirements for Fluoride Salt-Cooled High Temperature Reactor Components. Technical Rpt. ORNL/TM-2009/297, Oak Ridge National Laboratory, Oak Ridge, Tennessee.

Hong, YC, HS Uhm, BJ Chun, SK Lee, SK Hwang, and DS Kim. 2006. "Microwave Plasma Torch Abatement of $\mathrm{NF}_{3}$ and $\mathrm{SF}_{6} . "$ Physics of Plasmas 13:033508-7.

Iqbal, T, MR Shahriari, P Foy, and GH Sigel Jr. 1992. "Preliminary Study of Fiber Drawing of $\mathrm{AlF}_{3^{-}}$ Based Glasses." Materials Science and Engineering B 12:299-303.

Katsuhara, Y, M Aramaki, A Ishii, T Kume, C Kawashima, and S Mitsumoto. 2006. "Fluorine Chemistry at Central Glass." Journal of Fluorine Chemistry 127:8-17.

Kennedy, A and CB Colburn. 1961. "Strength of the N-F Bond in $\mathrm{NF}_{3}$ and of N-F and N-N Bonds in $\mathrm{N}_{2} \mathrm{~F}_{4} . "$ The Journal of Chemical Physics 35:1892-93.

Klapötke, TM. 2006. "Nitrogen-Fluorine Compounds." Journal of Fluorine Chemistry 127:679-87.

Lide, DR, ed. 2010. CRC Handbook of Chemistry and Physics, Internet Version 2009-2010. 90 ${ }^{\text {th }}$

Edition. Taylor and Francis, Boca Raton, Florida.

MacFadden, KO and E Tschuikow-Roux. 1973. "Spectrophotometric Determination of the Rate of Dissociation of Nitrogen Trifluoride Behind Shock Waves." J Physical Chemistry 77:1475-78. 
Mathews, AL and CF Baes. 1968. "Oxide Chemistry and Thermodynamics of Molten Lithium FluorideBeryllium Fluoride Solutions." Inorganic Chemistry 7:373-82.

Maze, G, V Cardin, and M Poulain. 1984. "Reduction of $\mathrm{OH}^{-}$-Absorption in Fluoride Glasses." Journal of Lightwave Technology, 2:596-99.

McNamara, B, R Scheele, A Kozelisky, and M Edwards. 2009. "Thermal Reactions of Uranium Metal, $\mathrm{UO}_{2}, \mathrm{U}_{3} \mathrm{O}_{8}, \mathrm{UF}_{4}$, and $\mathrm{UO}_{2} \mathrm{~F}_{2}$ with $\mathrm{NF}_{3}$ to Produce $\mathrm{UF}_{6}$." Journal of Nuclear Materials 394:166-73.

Molina, LT, PJ Wooldridge, and MJ Molina. 1995. "Atmospheric Reactions and Ultraviolet and Infrared Absorptivities of Nitrogen Trifluoride." Geophys. Res. Lett. 22:1873-76.

Nakai, T, Y Mimura, O Shinbori, and H Tokiwa. 1985. "Elimination of Complex Ions in Flouride Glasses by $\mathrm{NF}_{3}$ Processing." Japanese Journal of Applied Physics 24:1658-60.

Nakai, T, Y Mimura, H Tokiwa, and O Shinbori. 1986. "Dehydration of Fluoride Glasses by $\mathrm{NF}_{3}$ Processing." Journal of Lightwave Technology LT-4:87-89.

Occupational Safety and Health Administration (OSHA). 1993. "Chemical Sampling Information Nitrogen Trifluoride." Washington, D.C.

Occupational Safety and Health Administration (OSHA). 2006. "Chemical Sampling Information Hydrogen Fluoride." Washington, D.C.

Olson, LC, JW Ambrosek, K Sridharan, MH Anderson, and TR Allen. 2009. "Materials Corrosion in Molten LiF-NaF-KF Salt." Journal of Fluorine Chemistry 130:67-73.

Patnaik, P. 2003. "Nitrogen Trifluoride." In Handbook of Inorganic Chemicals, pp. 655-56. McGrawHill, New York.

Petti, DA, GR Smolik, MF Simpson, JP Sharpe, RA Anderl, S Fukada, Y Hatano, M Hara, Y Oya, T Terai, DK Sze, and S Tanaka. 2006. "Jupiter-II Molten Salt Flibe Research: An Update on Tritium, Mobilization and Redox Chemistry Experiments." Fusion Engineering and Design 81:1439-49.

Poling, B, J Prausnitz, and J O'Connell. 2001. "Properties of Gases and Liquids." McGraw-Hill, New York.

Poulain, M. 1983. "Halide Glasses." Journal of Non-Crystalline Solids 56:1-14.

Prather, MJ and J Hsu. 2008. "NF 3 , the Greenhouse Gas Missing from Kyoto." Geophys. Res. Lett. 35:L12810.

Praxair, Inc. 1997. "Abatement of Emissions of Global Warming Gases." Praxair Technology Inc.

Radoiu, M and S Hussain. 2009. "Microwave Plasma Removal of Sulphur Hexafluoride." Journal of Hazardous Materials 164:39-45.

Robinson, M, RC Pastor, RR Turk, DP Devor, M Braunstein, and R Braunstein. 1980. "InfraredTransparent Glasses Derived from the Fluorides of Zirconium, Thorium, and Barium." Materials Research Bulletin 15:735-42. 
Robson, JI, LK Gohar, MD Hurley, KP Shine, and TJ Wallington. 2006. "Revised IR Spectrum, Radiative Efficiency and Global Warming Potential of Nitrogen Trifluoride." Geophys. Res. Lett. 33:L10817.

Roine, A, T Kottiranta, P Lamberg, J Mansikka-Aho, P Bjorklund, J-P Kentala, T Talonen, R Ahlberg, A Grohn, O Saarinen, J Myyri, J Sipila, et al. 2009. "HSC Chemistry 7.00." Outotec Research Oy, Pori, Finland.

Schott, GL, LS Blair, and JDJ Morgan. 1973. "Exploratory Shock-Wave Study of Thermal Nitrogen Trifluoride Decompostion and Reactions of Nitrogen Trifluoride and Dinitrogen Tetrafluoride with Hydrogen." J Physical Chemistry 77:2823-30.

Shaffer, JH. 1971. Preparation and Handling of Salt Mixtures for the Molten Salt Reactor Experiment. Technical Rpt. ORNL-4616, Oak Ridge National Laboratory, Oak Ridge, Tennessee.

Smith, R. 2010. "Fluorine Compounds, Inorganic, Hydrogen." In Kirk-Othmer Encyclopedia of Chemical Technology. John Wiley \& Sons, New York.

Technical Resources International, Inc. 2001. Summary of Data for Chemical Selection: Nitrogen Trifluoride. Technical, National Toxicology Program, Department of Health and Human Services, Washington DC.

Tompkins, JF and ESJ Wang. 1966. "Electrolytic Method of Producing Nitrogen Trifluoride." United States Patent 3,235,474.

Tsai, W-T. 2008. "Environmental and Health Risk Analysis of Nitrogen Trifluoride $\left(\mathrm{NF}_{3}\right)$, a Toxic and Potent Greenhouse Gas." Journal of Hazardous Materials 159:257-63.

U.S. Climate Change Technology Program. 2003. "Emissions of High Global-Warming Potential Gases." In Semiconductor Industry: Abatement Technologies, pp. 176-178. Washington, DC

U.S. DOE Nuclear Energy Research Advisory Committee, and Generation IV International Forum. 2002. A Technology Roadmap for Generation IV Nuclear Energy Systems. U.S. Department of Energy, Washington D.C.

Vileno, E, MK LeClair, SL Suib, MB Cutlip, FS Galasso, and SJ Hardwick. 1995. "Thermal Decomposition of $\mathrm{NF}_{3}$ by Ti, Si, and Sn Powders." Chemistry of Materials 7:663-87.

Vileno, E, MK LeClair, SL Suib, MB Cutlip, FS Galasso, and SJ Hardwick. 1996. "Thermal Decomposition of $\mathrm{NF}_{3}$ with Various Oxides." Chemistry of Materials 8:1217-21.

Wagman, D, W Evans, V Parker, R Schumm, I Halow, S Bailey, K Churney, and R Nuttal. 1982. "The NBS Tables of Chemical Thermodynamic Properties - Selected Values for Inorganic and $\mathrm{C}_{1}$ and $\mathrm{C}_{2}$ Organic Substances in SI Units." Journal of Physical and Chemical Reference Data 11 Supplement No. 2.

Weiss, RF, J Mühle, PK Salameh, and CM Harth. 2008. "Nitrogen Trifluoride in the Global Atmosphere." Geophys. Res. Lett. 35:L20821.

Williams, DF. 2006. Assessment of Candidate Molten Salt Coolants for the NGNP/NHI Heat-Transfer Loop. Technical Rpt. ORNL/TM-2006/69, Oak Ridge National Laboratory, Oak Ridge, Tennessee. 
Williams, DF, LM Toth, and KT Clarno. 2006. Assessment of Candidate Molten Salt Coolants for the Advanced High-Temperature Reactor (AHTR). Technical Rpt. ORNL/TM-2006/12, Oak Ridge National Laboratory, Oak Ridge, Tennessee.

Woytek, AJ and JT Lileck. 1978. "Preparation of Nitrogen Trifluoride." United States Patent 4,091,081. 




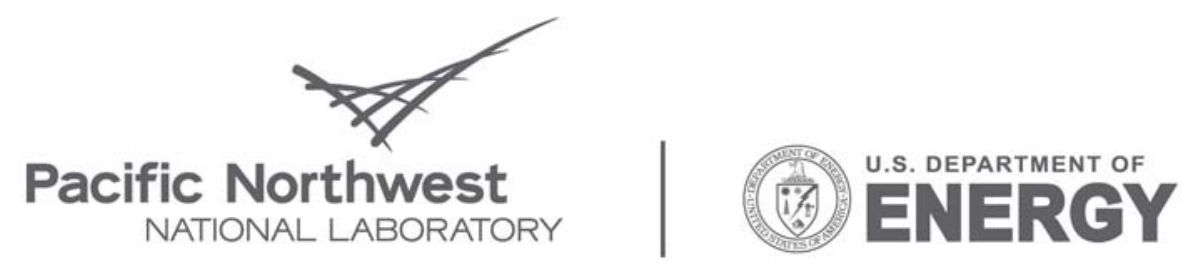

Proudly Operated by Battelle Since 1965

902 Battelle Boulevard

P.O. Box 999

Richland, WA 99352

1-888-375-PNNL (7665)

www.pnl.gov 